\title{
Comparison of Groundwater Seepage Modeling in Approximate Original Contour and Geomorphic Valley Fill Design
}

\author{
Nathan C. DePriest \\ West Virginia University
}

Follow this and additional works at: https://researchrepository.wvu.edu/etd

\section{Recommended Citation}

DePriest, Nathan C., "Comparison of Groundwater Seepage Modeling in Approximate Original Contour and Geomorphic Valley Fill Design" (2012). Graduate Theses, Dissertations, and Problem Reports. 470. https://researchrepository.wvu.edu/etd/470

This Thesis is protected by copyright and/or related rights. It has been brought to you by the The Research Repository @ WVU with permission from the rights-holder(s). You are free to use this Thesis in any way that is permitted by the copyright and related rights legislation that applies to your use. For other uses you must obtain permission from the rights-holder(s) directly, unless additional rights are indicated by a Creative Commons license in the record and/ or on the work itself. This Thesis has been accepted for inclusion in WVU Graduate Theses, Dissertations, and Problem Reports collection by an authorized administrator of The Research Repository @ WVU. For more information, please contact researchrepository@mail.wvu.edu. 
Comparison of Groundwater Seepage Modeling in Approximate Original Contour and Geomorphic Valley Fill Design

Nathan C. DePriest

\begin{abstract}
Thesis submitted to the
Benjamin M. Statler College of Engineering and Mineral Resources at West Virginia University

in partial fulfillment of the requirements

for the degree of

Master of Science

in

Civil and Environmental Engineering
\end{abstract}

Dr. John D. Quaranta, Ph.D., P.E., Chair

Dr. Hema Siriwardane, Ph.D., P.E.

Dr. Leslie Hopkinson, Ph.D.

Dr. Lian-Shin Lin, Ph.D., P.E.

Department of Civil and Environmental Engineering

Morgantown, West Virginia

2012

Keywords: valley fill, groundwater, seepage, slope stability, modeling, geomorphic, AOC Copyright 2012 Nathan C. DePriest 


\begin{abstract}
Comparison of Groundwater Seepage Modeling in Approximate Original Contour and Geomorphic Valley Fill Design
\end{abstract}

Nathan C. DePriest

Excess spoil generated during surface mining in southern West Virginia is generally placed in headwater valleys. Known as valley fills, these structures are designed to move water rapidly through constructed drains to maximize geotechnical stability using the conventional design method termed Approximate Original Contour (AOC). Seepage from valley fills tends to be elevated with respect to calcium, magnesium, alkalinity and sulfates and there is evidence that, in high concentrations, these ions can contribute to stream degradation. New fluvial geomorphic principals are being researched to aid in reclamation alternatives to AOC designs. Geomorphic designs have proven successful in semi-arid regions; however, there has been little research performed into the application of this approach for eastern surface mining reclamation.

This research investigated the differences in seepage quality and quantity between the AOC method and geomorphic designs on a permitted valley fill in southern West Virginia. The computational modeling involved geomorphic design for a proposed valley fill in southern West Virginia using commercial software. A comprehensive seepage analysis was then developed using a finite element method numerical model for assessing the groundwater flow characteristics of the fill rock for a 10 year time period. A resultant slope stability analysis was also performed. These analyses were performed for both the AOC and geomorphic fill designs.

Differences in seepage and slope stability for the AOC and geomorphic fill were presented and discussed as a comparison of the two designs. Analysis criteria were chosen as a way to compare the results of the two fills in order to investigate if an advantage for one fill design was apparent. If an advantage of one fill was apparent, the magnitude of the advantage was quantified using a percent change in results. The results projected that higher water velocities (decreased residence times) occurred through mine spoil reclaimed according to the geomorphic fill design. Shorter hydraulic transit times through the spoil are expected to result in lower ionic concentrations in discharge water. The geomorphic fill had an advantage in the behavior of groundwater seepage for the majority of the time frame of the transient analysis, as well as in regards to slope stability.

The geomorphic fill had peaks in advantage in water velocity at the toe of $1291.1 \%$ at year 3 and $1646.6 \%$ at year 7 , peaks in advantage in water flux at the toe of $405.4 \%$ at year 3 and $1141.7 \%$ at year 7, peaks in advantage in maximum hydraulic velocity of $482.1 \%$ at year 3 and $1273.7 \%$ at year 7 , and a peak in advantage in storage of $24.3 \%$ in year 6 . For each of these criteria, the magnitude of the advantage for the geomorphic fill was much higher than the magnitude of any advantage for the AOC fill. This advantage was a result of the geomorphic fill moving water through the fill at a faster rate. This advantage in seepage could translate into an advantage in contaminant transport by water having less contact time with the fill material. 


\section{ACKNOWLEDGMENTS}

I would like to express my gratitude to my advisor, Dr. John D. Quaranta, for all of his guidance and assistance in completing this research project. His treatment of me as a colleague provided invaluable help throughout the completion of this thesis.

I wish to thank Dr. Leslie Hopkinson, Dr. Hema J. Siriwardane, and Dr. Lance Lin for being on my advisory committee.

I wish to thank Mr. Harold Russell for assistance in the laboratory testing and numerical modeling. I wish to thank Ms. Allison Sears for the development of slope designs used for my numerical modeling.

I also wish to thank the engineers and staff members from Coal-Mac, Incorporated who provided support for the program.

I would like to dedicate this thesis to my family, who has supported me throughout this entire process. 


\section{TABLE OF CONTENTS}

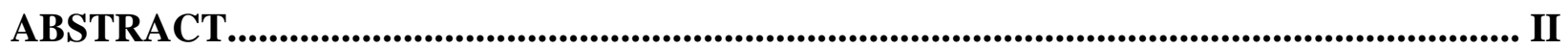

ACKNOWLEDGMENTS ..................................................................................................

TABLE OF CONTENTS ........................................................................................................................ II

TABLE OF FIGURES .......................................................................................................................... V

LIST OF TABLES .....................................................................................................

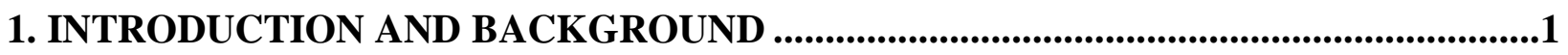

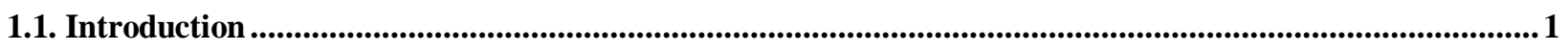

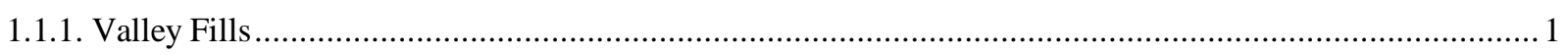

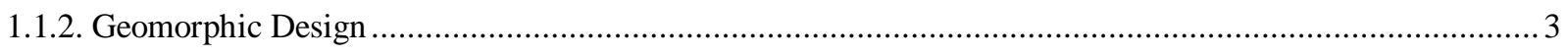

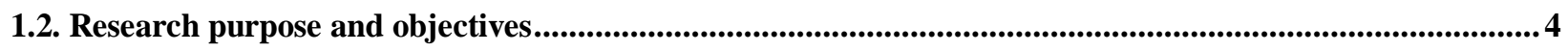

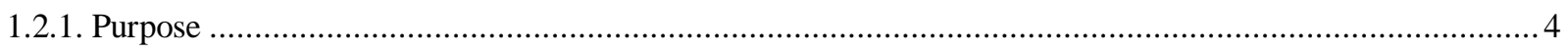

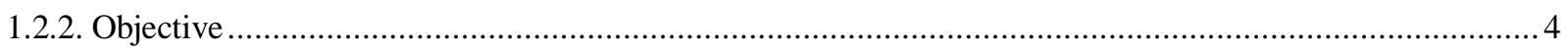

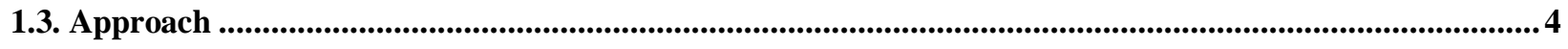

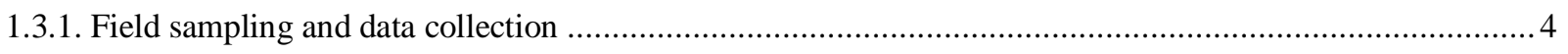

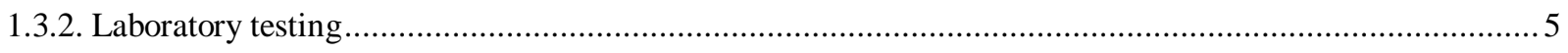

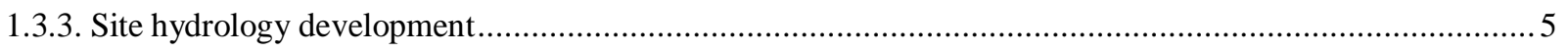

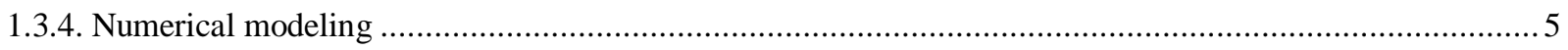

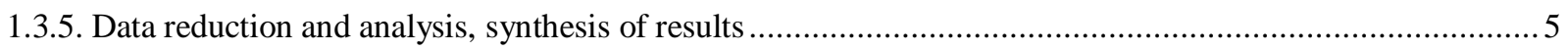

2. LITERATURE REVIEW ....................................................................................................6

2.1. Unsaturated Soil Property Functions ...........................................................................................................................6

2.2. Cover Systems for Waste Rock Tailings.......................................................................................................................... 8 
3. MATERIALS \& METHODS ..........................................................................................10

3.1. Field Site and Sampling ................................................................................................................................. 10

3.2. Soil Testing......................................................................................................................................................... 11

3.3. Site Hydrology ……................................................................................................................................................ 12

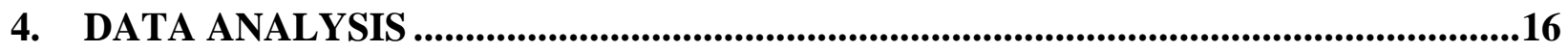

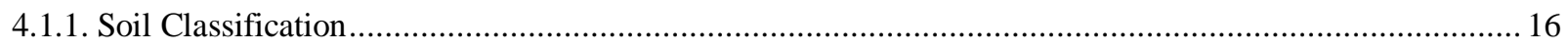

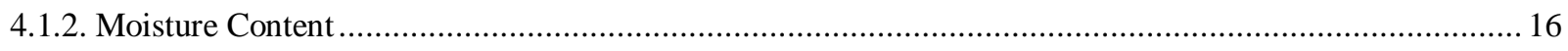

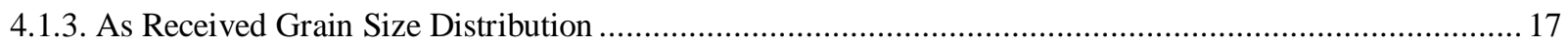

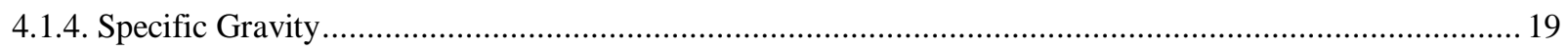

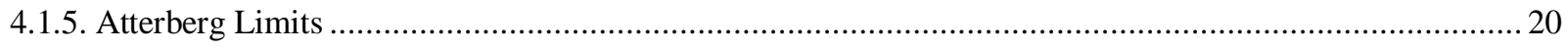

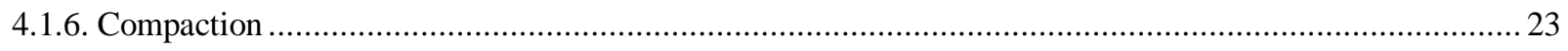

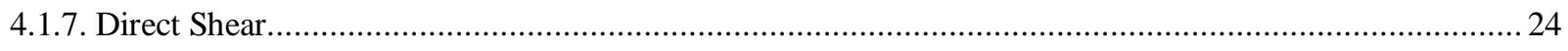

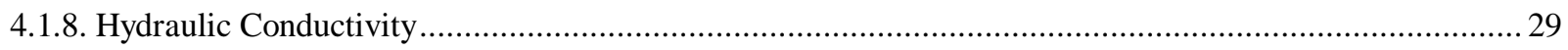

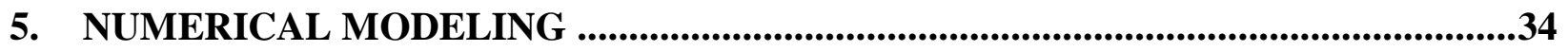

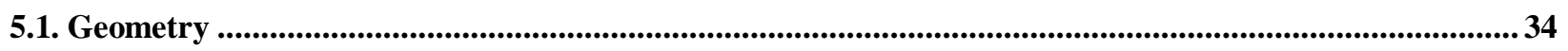

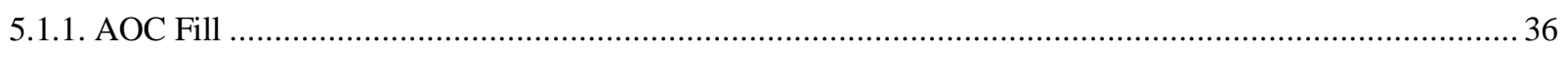

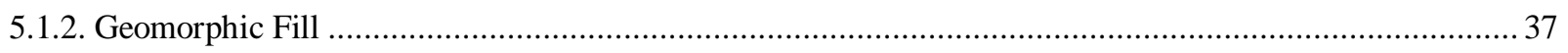

5.2. Groundwater Seepage Modeling ..................................................................................................................................39

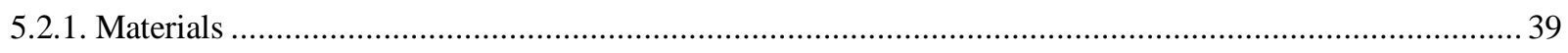

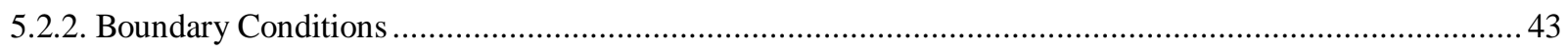

5.3. Deformation and Slope Stability Modeling …….......................................................................................................... 48

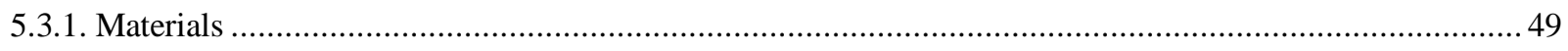

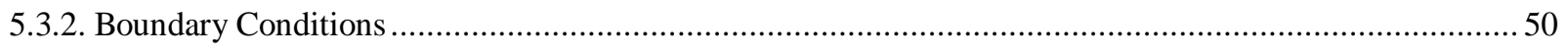

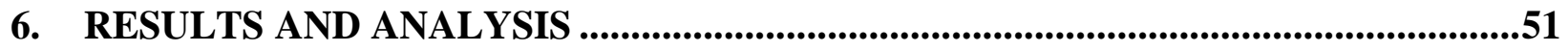




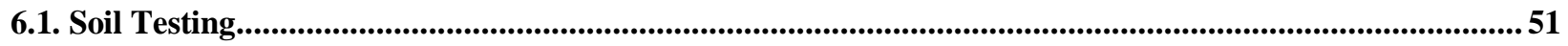

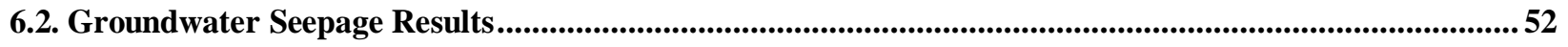

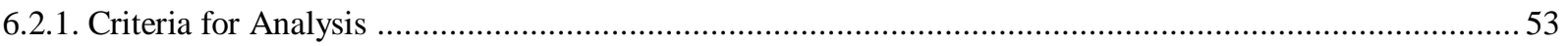

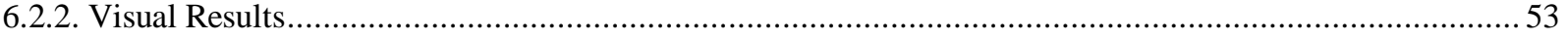

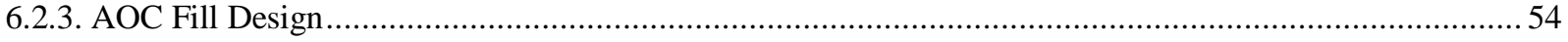

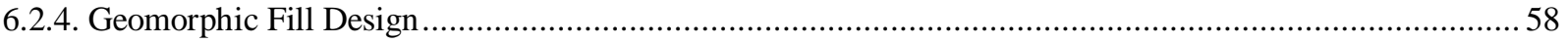

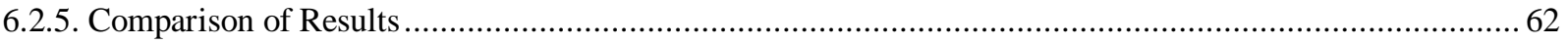

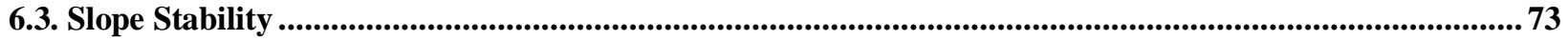

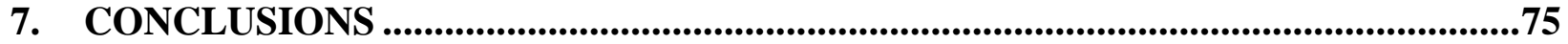

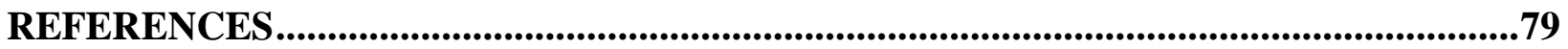




\section{TABLE OF FIGURES}

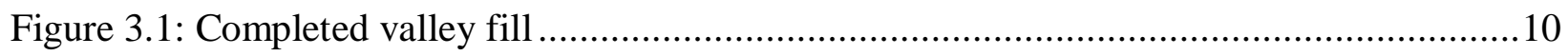

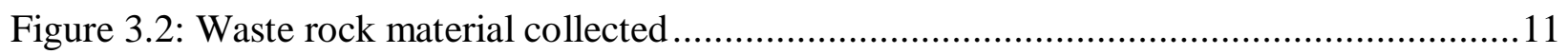

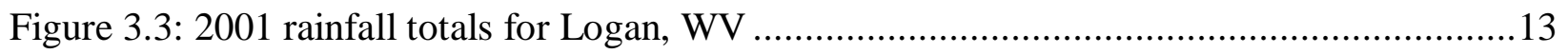

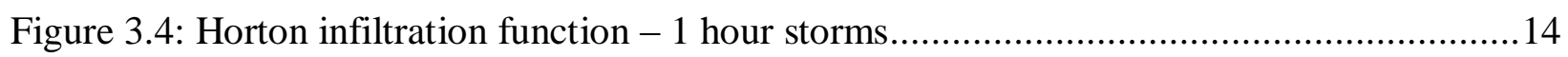

Figure 3.5: Horton infiltration function -24 hour storms.................................................... 15

Figure 4.1: As received grain size distribution .....................................................................18

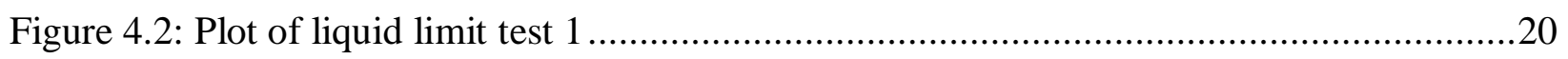

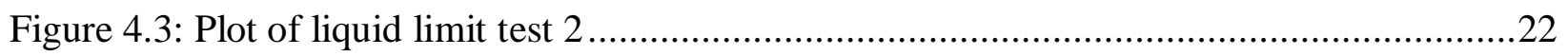

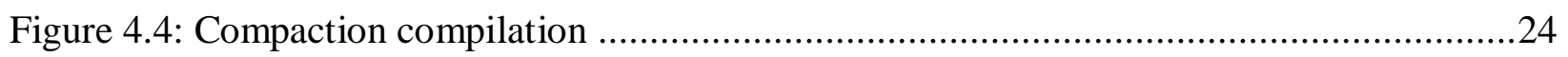

Figure 4.5: Valley fill profile used for direct shear tests......................................................25

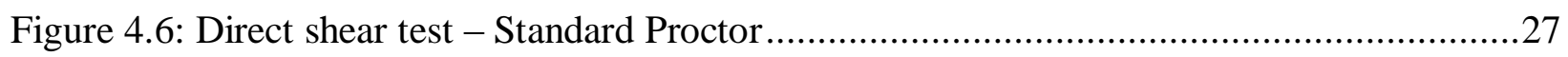

Figure 4.7: Direct shear test $-34 \%$ of Standard Proctor.............................................................28

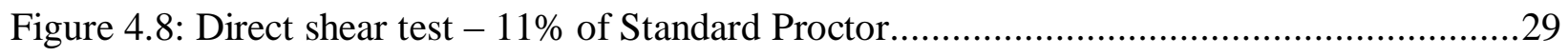

Figure 4.9: Hydraulic conductivity - Standard Proctor ..............................................................30

Figure 4.10: Hydraulic conductivity - 34\% of Standard Proctor ................................................

Figure 4.11: Hydraulic conductivity - 11\% of Standard Proctor ……………...........................33

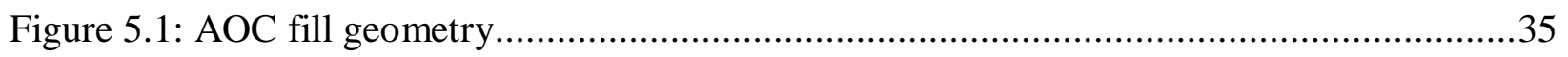

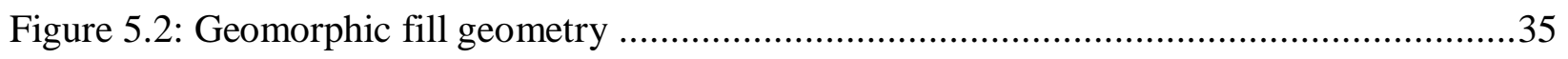

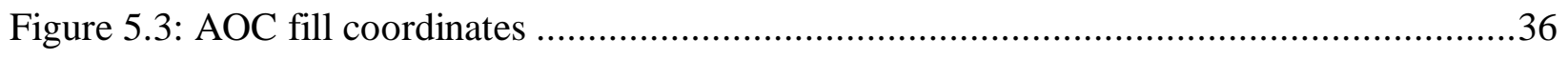

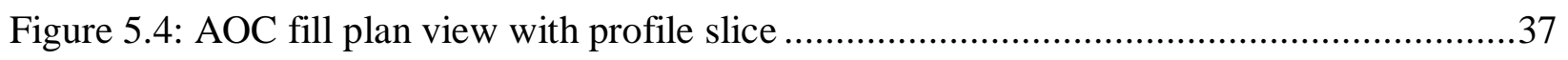

Figure 5.5: Geomorphic fill plan view with profile slice ............................................................38

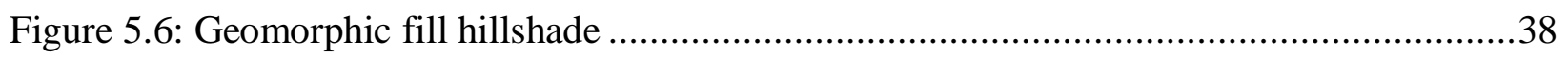

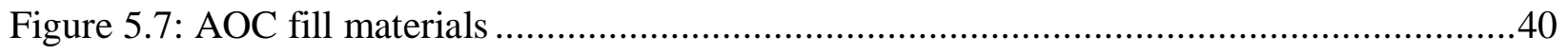




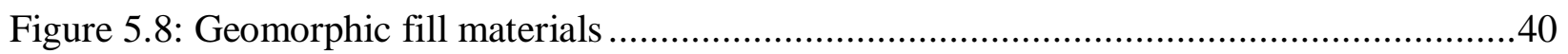

Figure 5.9: Fill conductivity function - AOC fill .................................................................

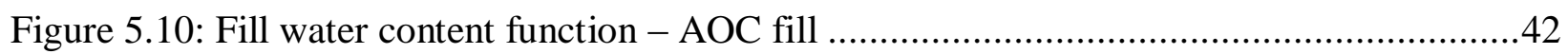

Figure 5.11: 55\% infiltration function for valley fill ........................................................... 44

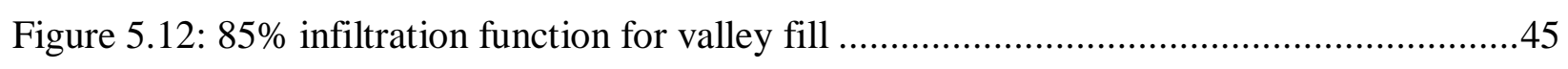

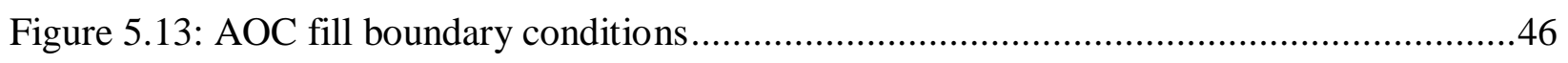

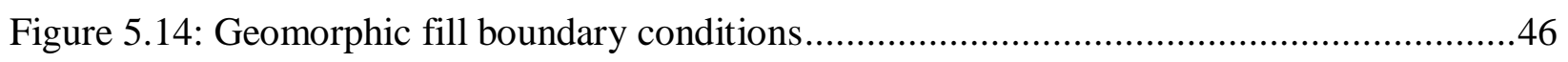

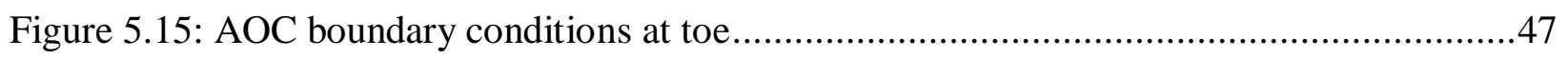

Figure 5.16: Geomorphic fill boundary conditions at toe ……..............................................48

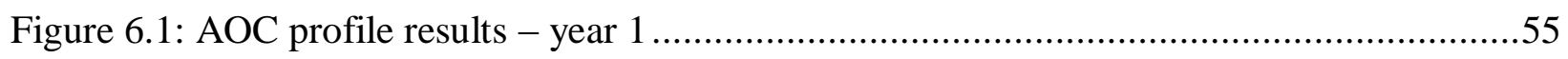

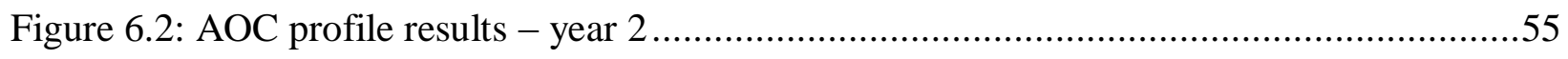

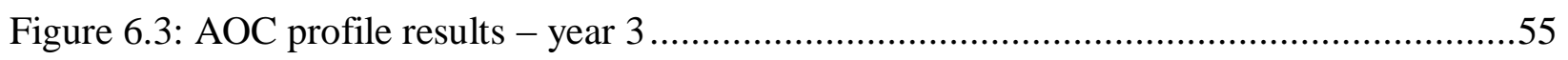

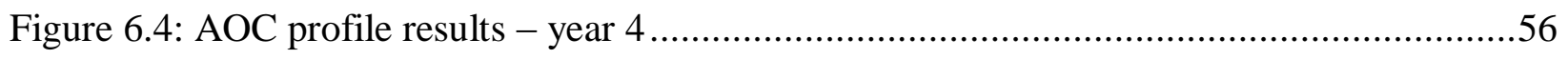

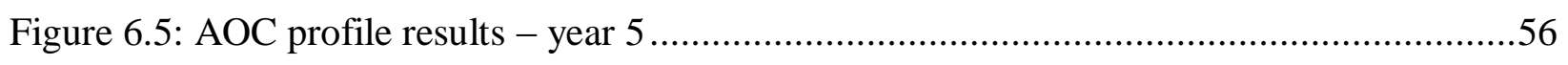

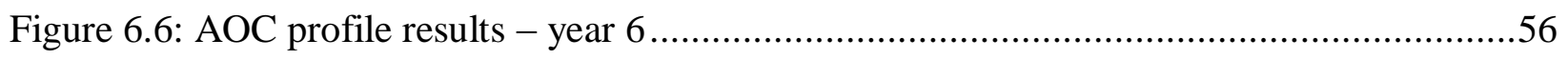

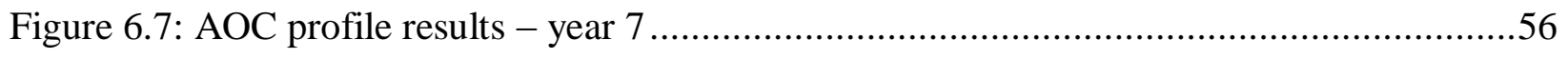

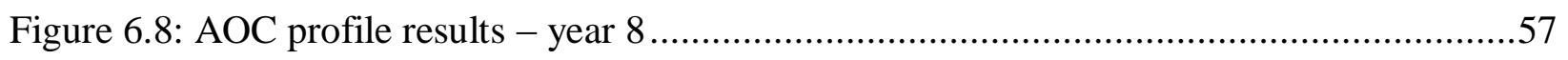

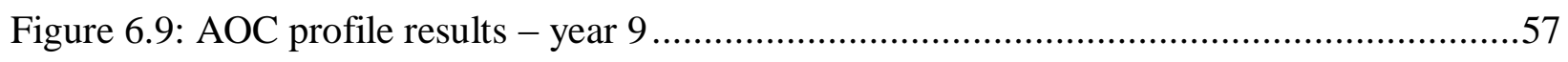

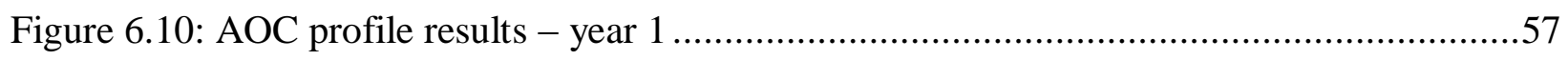

Figure 6.11: Geomorphic profile results - year 1 ……........................................................59

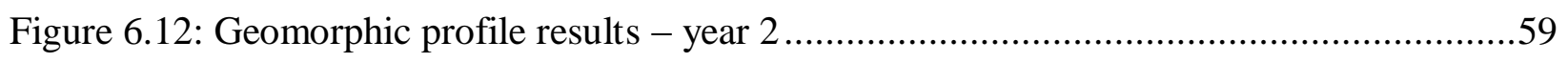

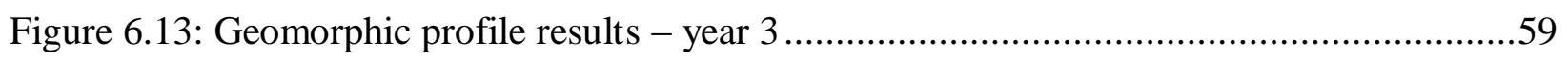

Figure 6.14: Geomorphic profile results - year 4 ……………...............................................60

Figure 6.15: Geomorphic profile results - year 5 …………..................................................60 


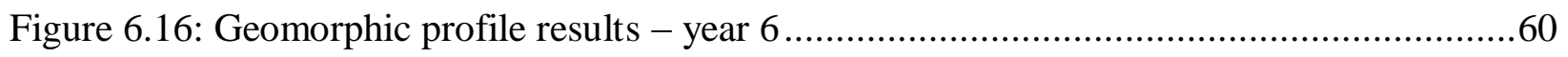

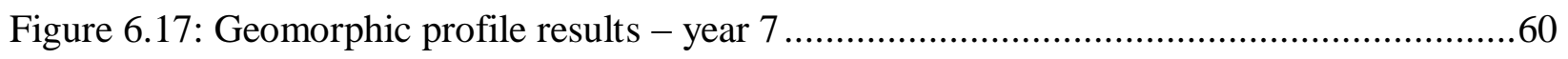

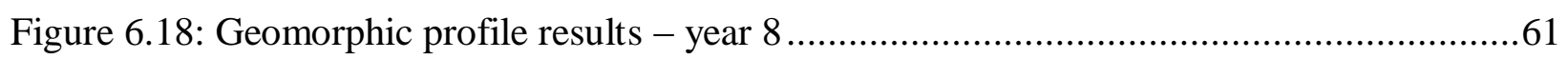

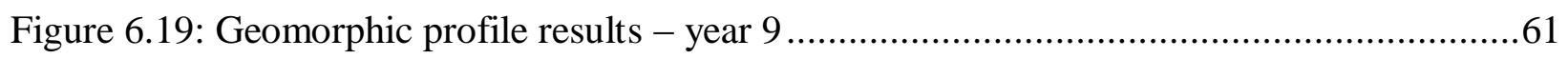

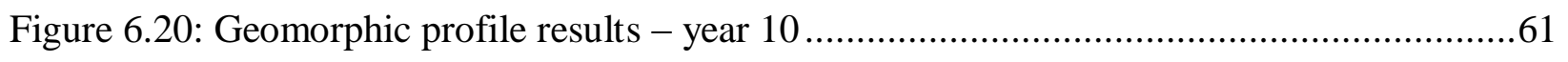

Figure 6.21: Normalized toe water velocity over time for both fills ..................................65

Figure 6.22: Percent change in water velocity at toe for AOC and geomorphic fills .................65

Figure 6.23: Normalized water flux at toe over time for both fills .......................................67

Figure 6.24: Percent change in water flux at toe for AOC and geomorphic fills ......................67

Figure 6.25: Normalized maximum hydraulic velocity over time for both fills ......................69

Figure 6.26: Percent change in maximum hydraulic velocity for AOC and geomorphic fills ......69

Figure 6.27: Normalized storage over time for both fills ........................................... 71

Figure 6.28: Percent change in storage for AOC and geomorphic fills ................................71 


\section{LIST OF TABLES}

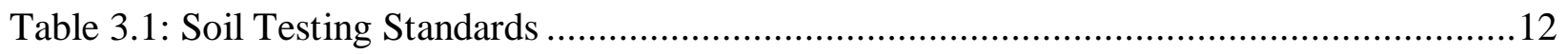

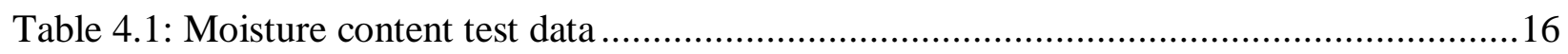

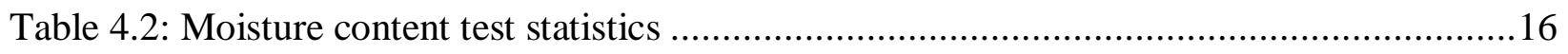

Table 4.3: Grain size distribution critical indices results .......................................................17

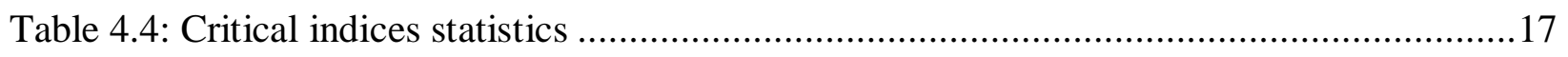

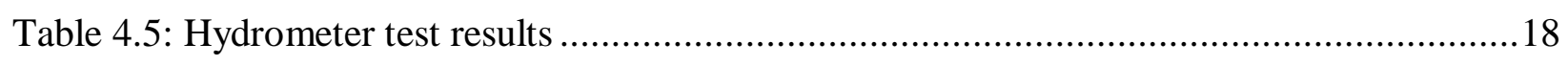

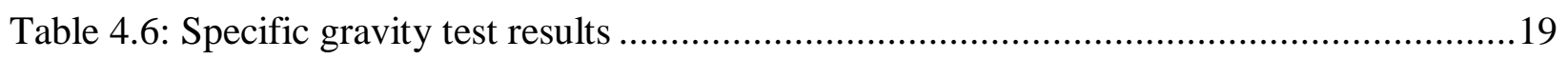

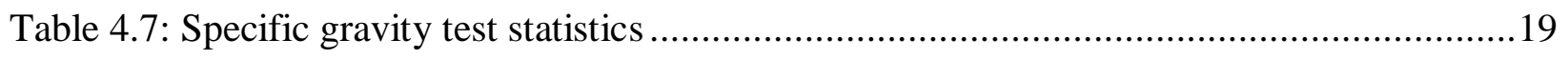

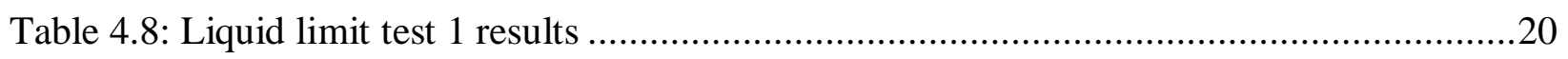

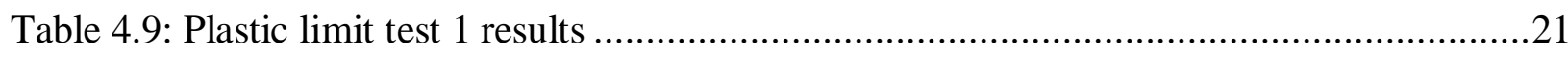

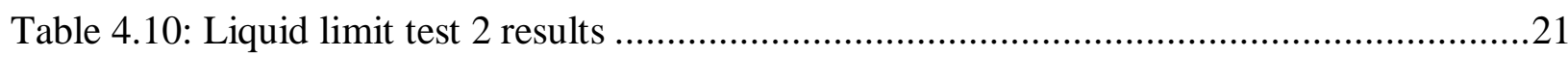

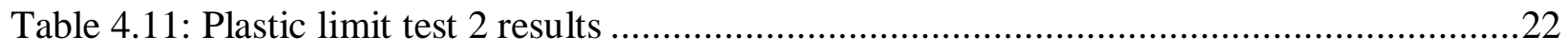

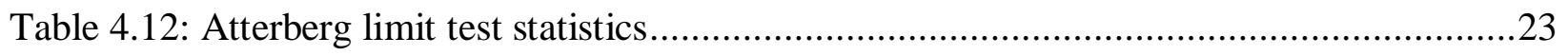

Table 4.13: Direct shear test data - Standard Proctor .............................................................26

Table 4.14: Direct shear test data $-34 \%$ of Standard Proctor..................................................27

Table 4.15: Direct shear test data $-11 \%$ of Standard Proctor.................................................28

Table 4.16: Hydraulic conductivity results - Standard Proctor......................................................30

Table 4.17: Hydraulic conductivity statistics - Standard Proctor ...............................................30

Table 4.18: Hydraulic conductivity results $-34 \%$ of Standard Proctor ....................................... 31

Table 4.19: Hydraulic conductivity statistics $-34 \%$ of Standard Proctor .....................................

Table 4.20: Hydraulic conductivity results $-11 \%$ of Standard Proctor ........................................32

Table 4.21: Hydraulic conductivity results $-11 \%$ of Standard Proctor …………………............33

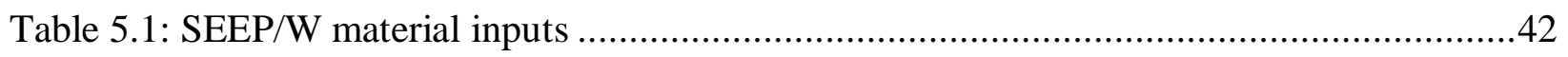


Table 5.2: SIGMA/W material inputs ........................................................................4 49

Table 5.3: SLOPE/W deterministic analysis material inputs .........................................49

Table 5.4: SLOPE/W sensitivity analysis material inputs ............................................50

Table 6.1: Soil property results with multiple tests ...................................................51

Table 6.2: Soil property results of tests run at different compaction energies .........................52

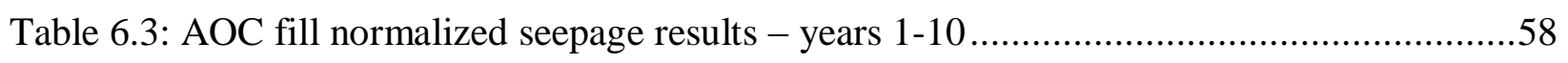

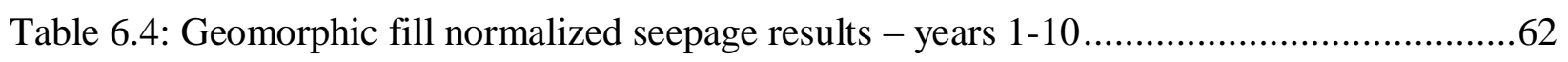

Table 6.5: Comparison of pore-water pressure results......................................................64

Table 6.6: Comparison of normalized toe water velocity results ...................................64

Table 6.7: Comparison of normalized toe water flux results .............................................66

Table 6.8: Comparison of normalized maximum hydraulic velocity results ..........................68

Table 6.9: Comparison of normalized storage results....................................................70

Table 6.10: Summary of percent change for AOC and geomorphic fills ..............................73

Table 6.11: Factor of safeties for AOC fill................................................................... 74

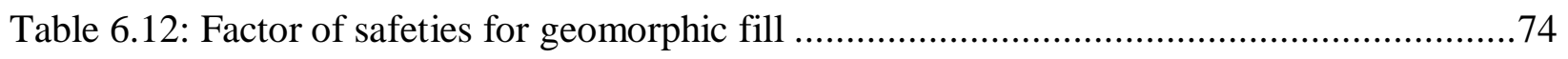




\section{INTRODUCTION AND BACKGROUND}

\subsection{Introduction}

The following section presents an introduction to the "Approximate Original Contour" and geomorphic techniques for the design of valley fills in West Virginia. These were the two design techniques analyzed in this research.

\subsubsection{Valley Fills}

Surface coal mining is a dominant land use in the Central Appalachian region of West Virginia. In surface mining, the overburden from the tops of mountains are removed to expose buried coal, which is then extracted. The bulk of mined rock (spoil) is placed on the mined surface while excess spoil is placed in external dumps known as valley fills. Bell et al. (1989) stated that mountaintop mining with valley fills (MTM/VF) is, by regulation, accomplished in accordance with “Approximate Original Contour", or AOC. This method consists of backfilling waste rock from a highwall in benches to approximately recreate the mountain's original contour. The West Virginia Department of Environmental Protection (1999) stated that AOC meets the valley fill design requirements, which are as follows which are as follows:

- long-term static factor of safety of 1.5 or higher

- $2: 1$ slopes with 20 - $\mathrm{ft}$ wide benches every 50 vertical feet

- a rock core

- properly designed drainage for 100-yr, 24-hr rain event

Although the AOC method of valley fill construction meets the requirements of a valley fill, some areas of concern remain. These include the long-term stability of the fill and the environmental impact in the surrounding area. Due to the steep surfaces required to recreate landforms in central Appalachia and seepage of water into the fills, slope failures have been occurred. Also, since valley fills extend into the bottom of valleys, their toe usually extends into the headwaters of streams. Palmer et al. (2010) stated that this has a detrimental effect on the ecosystems that rely on valley streams, causing biodiversity and water quality to suffer. Burial of headwater streams creates an environment that is not supportive of much of the aquatic life 
that thrives in Appalachian streams. Runoff increases after mining. Loss of topsoil and vegetation, compacted soil, and altered topography reduce infiltration rates. Lower infiltration rates result in greater storm runoff and more frequent and greater downstream flooding. Palmer et al. (2010) also stated that in addition to runoff, the water that comes out of the bottom of valley fills negatively affects downstream water quality. Streams below valley fills are found to have higher $\mathrm{pH}$, dissolved solids, sulfate concentrations, electrical conductivity, and metal concentrations (Mn, Fe, Al, Se), which all result in less biodiversity and inferior water quality.

A metal of particular concern is selenium. It is primarily present in shales and coals, and can also be found in coal overburden, which is the material used for construction of valley fills. High concentrations of selenium are found in the rock tailings used to construct valley fills. Selenium from tailings can be desorbed by infiltrating water. Once selenium is desorbed from waste rock and mobilized, it can enter discharge water, which then enters groundwater or surface water within the valley fill's drainage area. Selenium discharge concentrations are regulated at 5 $\mu \mathrm{g} / \mathrm{L}$ (micrograms/liter), but Ziemkiewicz (2011) found that discharges from surface mines in southern West Virginia many times have concentrations of selenium between 10 and $25 \mu \mathrm{g} / \mathrm{L}$. This study also showed that approximately $35 \%$ - 38\% of selenium in organic shales of southern West Virginia was mobile. High Se concentrations in streams can cause reproductive failure in fish, as well as selenium to bioaccumulate in organisms. Through bioaccumulation, Se can work its way up the food chain and cause reproductive failure in birds. Prolonged exposure to high concentrations can also have adverse health effects on humans.

AOC may meet the regulatory requirements for valley fills, but problems in certain areas show an opportunity for upgrades. The current mitigation strategy results in streams that may not meet established water quality standards and loss of stream habitat. Long-term instability, destruction of headwaters, higher runoff rates, desorption of contaminants from overburden, and degraded downstream water quality all point to the possibility for an improved method of reclamation for valley fills. 


\subsubsection{Geomorphic Design}

A method that shows promise to reduce the negative impacts of valley fill construction is geomorphic design. Geomorphic design seeks to develop a landscape that can be managed to achieve improvements in water quality. Martin-Duque et al. (2009) state that specifically, geomorphic design aims to produce valley fills that are more aesthetically pleasing and have a more natural look than AOC valley fills by incorporating natural landform shapes in design. Also, geomorphic design may provide greater stability through more natural slope profiles. In natural landforms, erosive forces balance with resistive forces over time. Geomorphic design creates a more natural landform that could have long-term equilibrium and low erosion rates. Another goal of geomorphic design is to improve runoff and groundwater seepage. By increasing runoff and reducing infiltration, groundwater seepage could be improved, which could aid in slope stability and contaminant transport.

New fluvial geomorphic principals are being researched to aid in reclamation alternatives to AOC designs. So far, this method has only been field tested in the United States in semi-arid regions, such as the study performed by Toy and Chuse (2005). Its use in the central Appalachian region that dominates West Virginia has not been analyzed. Designing natural landforms in the steep terrain of this region can prove to be very complex and require higher initial construction costs. Michael et al. (2009) found that regulations for geomorphic design are lacking and differ from already passed regulations for AOC. Geomorphic design is expected to counteract higher initial construction costs with lower long-term costs, but an experimental project using geomorphic design in central Appalachia is needed to provide a better comparison to AOC design. 


\subsection{Research purpose and objectives}

The following section defines the research purpose and objectives for the project.

\subsubsection{Purpose}

The purpose of this research was to perform an analysis to investigate the differences in seepage and slope stability between the AOC and geomorphic methods of valley fill design. Seepage and slope stability were modeled in valley fills on a permitted site in southern WV with differing design techniques: one using the established method of Approximate Original Contour (AOC) and one using the newly developed technique of geomorphic design.

\subsubsection{Objective}

The main objective of this research was to compare and contrast the groundwater seepage and slope stability in valley fills using both AOC and geomorphic design. The objective of these comparisons was to determine if any distinct advantages with respect to seepage or slope stability could be seen by choosing either AOC or geomorphic techniques when designing a valley fill.

\subsection{Approach}

The scope of the work provides the methods followed throughout this research. The proposed project tasks are discussed in brief in the following paragraphs.

\subsubsection{Field sampling and data collection}

A surface mine in southern WV was chosen as the research site. Soil samples were collected on which to perform geotechnical tests to classify and obtain engineering properties of the field material. Additional information, such as representative permit files and site maps, were collected to fully classify the site. These were used to obtain field parameter values and properties for materials. 


\subsubsection{Laboratory testing}

Soil samples from the mine spoil of a southern WV surface mine were collected. Laboratory tests were performed to obtain strength and performance characteristics. These included grain size distribution, water content, specific gravity, Atterberg limits, compaction, direct shear, and hydraulic conductivity. These tests were used to classify the soil and provide input parameters for later modeling.

\subsubsection{Site hydrology development}

The hydrologic conditions for the valley fill site were determined as inputs for seepage modeling. This consisted of identifying actual precipitation totals and runoff characteristics of the site to develop infiltration functions for individual storm events. This data was used in later development of boundary conditions for the numerical model.

\subsubsection{Numerical modeling}

The computational modeling involved geomorphic design for a proposed valley fill in southern West Virginia. A comprehensive seepage and slope stability analysis was then developed using the SEEP/W, SIGMA/W, and SLOPE/W modules of GeoStudio2007. These analyses were performed for the AOC and geomorphic fill designs.

\subsubsection{Data reduction and analysis, synthesis of results}

After completion of the numerical modeling, data were reduced for the results of each of the two fills. Results were then compared in tabular and graphical form to find benefits and contrasts to the AOC and geomorphic designs. 


\section{LITERATURE REVIEW}

This literature review will focus on previous work in the aspects of this project. The first is a method for developing unsaturated soil property functions. Next, it will introduce the idea of using cover systems with waste rock tailings to improve groundwater seepage behavior. This could in turn improve contaminant transport in valley fills.

\subsection{Unsaturated Soil Property Functions}

When modeling with saturated and unsaturated soil cycles, it is sometimes necessary to approximate functions for soil properties to input into the numerical model. These include the soil-water characteristic curve (water content vs. matric suction) and hydraulic conductivity functions (hydraulic conductivity vs. matric suction) of the soil. A study by Fredlund et al. (1997) discussed these issues. Fredlund (1997) stated that the soil-water characteristic curve has become very useful in the estimation of unsaturated soil property functions. Numerical modeling requires the use of nonlinear soil property functions when unsaturated soils are analyzed. This method seems to be gaining acceptance in the analysis of unsaturated soil systems in engineering practice. Fredlund (1997) stated that the behavior of unsaturated soils is a function of pore size geometry and distribution. The soil-water characteristic curve has become the main method for understanding this relationship and is used to compute approximate soil property functions in unsaturated soils. Unsaturated soil property functions plot unsaturated soil properties versus soil suction. Examples of soil property functions are coefficient of permeability, coefficient of water volume change, and shear strength. These properties can be easily tested in the laboratory, but a way to economically complete the tests has not yet been determined. Unsaturated soil property tests can be costly. For this reason, the use of the soil-water characteristic curve to predict unsaturated soil property functions has been investigated. Some inaccuracies may be associated with this method, but the problems associated with these inaccuracies are outweighed by the benefits of the savings in cost.

Fredlund et al. (1997) stated that the use of "knowledge-based system" was the most effective method of determining unsaturated soil property functions. A knowledge-based system uses a database of soils whose soil-water characteristic curves have already been classified. Three 
procedures can use the database to obtain unsaturated soil property functions. First, a measured soil-water characteristic curve could be directly matched to a soil-water characteristic curve already in the database. The second method consisted of using measured soil classification properties to match with one or more soils in the database and therefore match to a soil-water characteristic curve. The third procedure involved comparing the soil's grain size distribution curve to the grain size curves of soils in the database. Once the corresponding soil-water characteristic curve was found, the appropriate unsaturated soil properties could be computed. These methods were found to have several advantages. The estimation of the unsaturated soil properties was quickly available, cost efficient, and easily completed by inexperienced professionals. Fredlund et al. (1997) stated that the program SoilVision used a database of over 600 soils to estimate unsaturated soil property functions using a knowledge-based approach.

Fredlund used an environmental application example to demonstrate the use of this knowledgebased system. Water seepage through mine tailings of a mine site in Papua, New Guinea was analyzed. A steady state and transient analysis were conducted. The steady state analysis used rainfall totals to determine the location of the water table. The transient analysis simulated a drought that desaturated the tailings. The transient analysis required the estimation of a soilwater characteristic curve and hydraulic conductivity curve. The mine tailings were found to have a void ratio of 0.80 , a saturation of $98 \%$, and a specific gravity of 2.66. A grain sizedistribution for the tailings was also developed. These soil properties were input into SoilVision and used to classify the soil. The tailings were classified as a sand. SoilVision then used the volume-mass properties and grain-size distribution to predict the soil-water characteristic curve using the van-Genuchten equation and a saturated volumetric water content of $44 \%$. Next, the hydraulic conductivity for the soil was developed. SoilVision used the soil's saturated hydraulic conductivity $\left(1.1 \times 10^{-5} \mathrm{~m} / \mathrm{s}\right)$ and the soil-water characteristic curve to estimate the full hydraulic conductivity curve. These soil property functions were then input as the material properties in a transient groundwater seepage analysis using the SEEP/W module of GeoStudio.

The following conclusions were made from this study: the soil-water characteristic curve is valuable in estimating unsaturated soil property functions; nonlinear soil property functions are necessary in numerical modeling, particularly transient groundwater seepage; a "knowledge- 
based approach" for determining unsaturated soil property functions is advantageous to determining the properties using laboratory testing; a "knowledge-based approach" can be used to adequately develop a soil-water characteristic curve and hydraulic conductivity curve for the numerical modeling of seepage through mine waste rock.

\subsection{Cover Systems for Waste Rock Tailings}

A major concern at mining sites is the discharge of contaminated seepage from waste materials. Cover systems can be used to mitigate this contamination by improving the behavior of groundwater seepage in waste rock material. Deissmann et al. (2003) discussed cover use and design in uranium mining waste dumps. The focus of this paper was on cover systems with a compacted and saturated clay layer to reduce infiltration of water and oxygen into waste materials. Minimizing the mobilization of contaminants from waste materials improved the amount of contaminated seepage through the use of covers containing compacted soil layers at high saturation, modified mining materials, or synthetic liners. The use of a cover system could decrease the environmental impacts of mining and aid in the positive use of a formerly mined area. A cover system could not reduce the contamination potential of mine waste, but it lengthened the time of contaminant release. This resulted in less of a contaminant load discharged over a longer period of time so that concentration of contaminants in discharge water bodies was not in excess of the acceptable level. Post discharge water treatment could still be required, but its long-term cost could be lower due to technological improvements in water treatment. Deissmann stated that ecosystem aspects, future land use and climate, and waste and cover material characteristics must be considered when constructing a cover system, with a goal of minimizing mitigation costs for the mining site. This included the cost of construction, water treatment, maintenance/monitoring, and detrimental environmental impacts.

The MEND (Mine Environment Neutral Drainage) Report (2004) extended the realm of cover systems to include use in waste rock and tailings. Waste rock and coal tailings are what are used

in valley fills, so the information in this report could be applied to their construction. First, to determine if the use of a cover system was appropriate for a site, the site had to be characterized. All existing site data had to be compiled, such as precipitation and site geometry. This was followed by an initial site survey to determine the type and amount of each type of soil. Soil was 
characterized in the lab through geotechnical and geochemical testing to determine if it had the appropriate characteristics, such as low hydraulic conductivity, to perform well as a cover. Once all site data was collected and soil testing completed, the information could be input into a computer program to model the flow of water through the cover system and the desorption of selenium.

The MEND report (2004) also described cover system design. A critical parameter in the design of covers was storage capacity, or the volume of water a soil can hold between its wettest and driest conditions. A cover with a higher storage capacity could hold more water and prevent infiltration of water for a longer period of time. Multilayer cover systems could be used to further reduce hydraulic conductivity by placing a finer material over a coarser material. This made the cover more resistant to the processes that deteriorated the system, such as freeze-thaw cycles and extreme climate events. A multilayer system also maintained near saturated conditions in all climates, and restricted upward capillary rise from underneath layers. On a sloping surface such as a valley fill, water would infiltrate into the top, finer material layer and then be transported down the slope. The top layer's ability to store precipitation stopped the water before it infiltrated into the next layer with higher hydraulic conductivity. The MEND report showed the necessity of analyzing a mine waste soil's ability to move and store water. The behavior of groundwater seepage and runoff is vital in determining the practicality of a design. 


\section{MATERIALS \& METHODS}

The following section describes the materials and methods of this experiment. The first step in this consisted of material collection from a field site. Next, geotechnical testing was performed to determine the material and engineering properties. The results of these tests were then used as inputs to perform numerical modeling with regards to seepage and slope stability in varying valley fill designs.

\subsection{Field Site and Sampling}

The material selected for this research was a gray crushed rock material retrieved from a surface mine site in Logan County, West Virginia on a hot, dry day. The samples were obtained from the disturbed area at an active surface mine reclamation site where piles of end dumped material were allotted some time to be exposed to the elements. The samples were obtained prior to any leveling or compaction effort. A tour of the surface mine was conducted. This included visiting a completed valley fill, an active surface mining area, a valley fill under construction, and a stream at the toe of a completed valley fill. The photos in Figures 3.1 and 3.2 below show different locations visited throughout the trip.

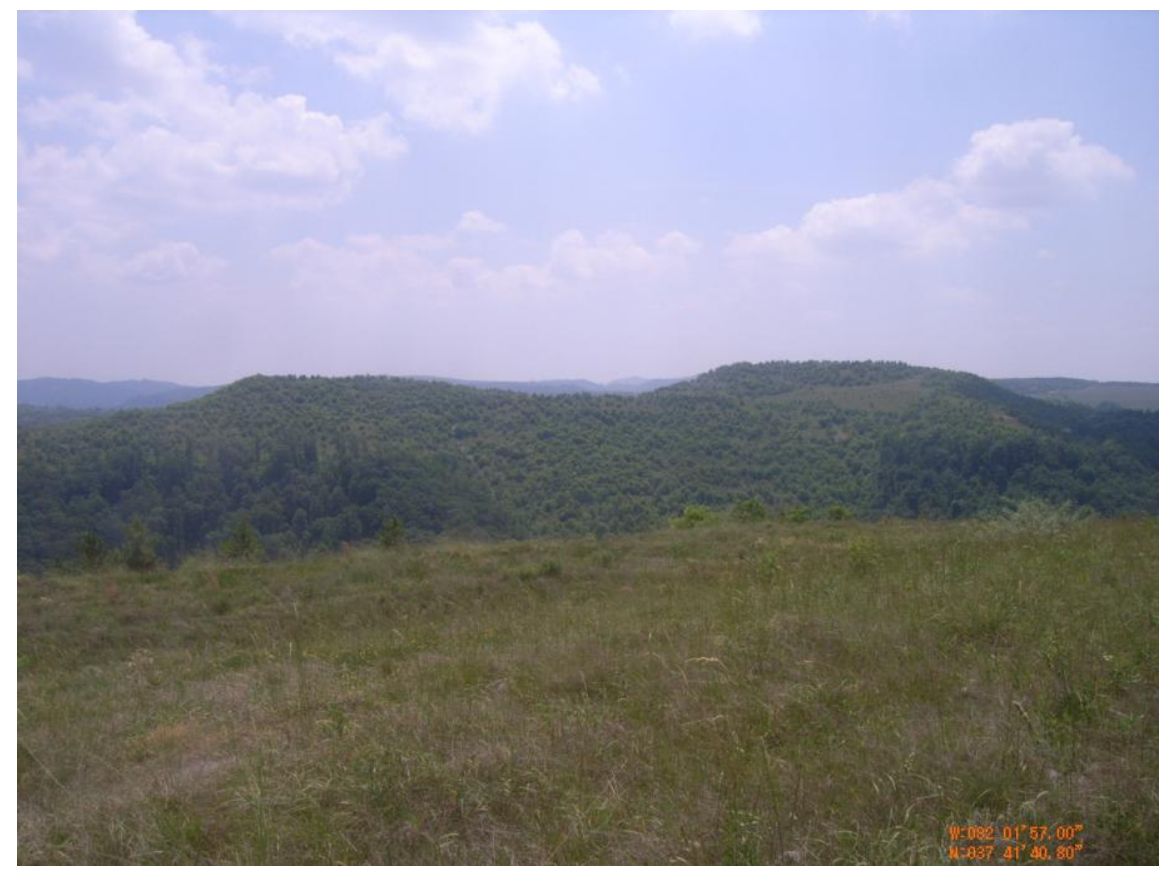

Figure 3.1: Completed valley fill 


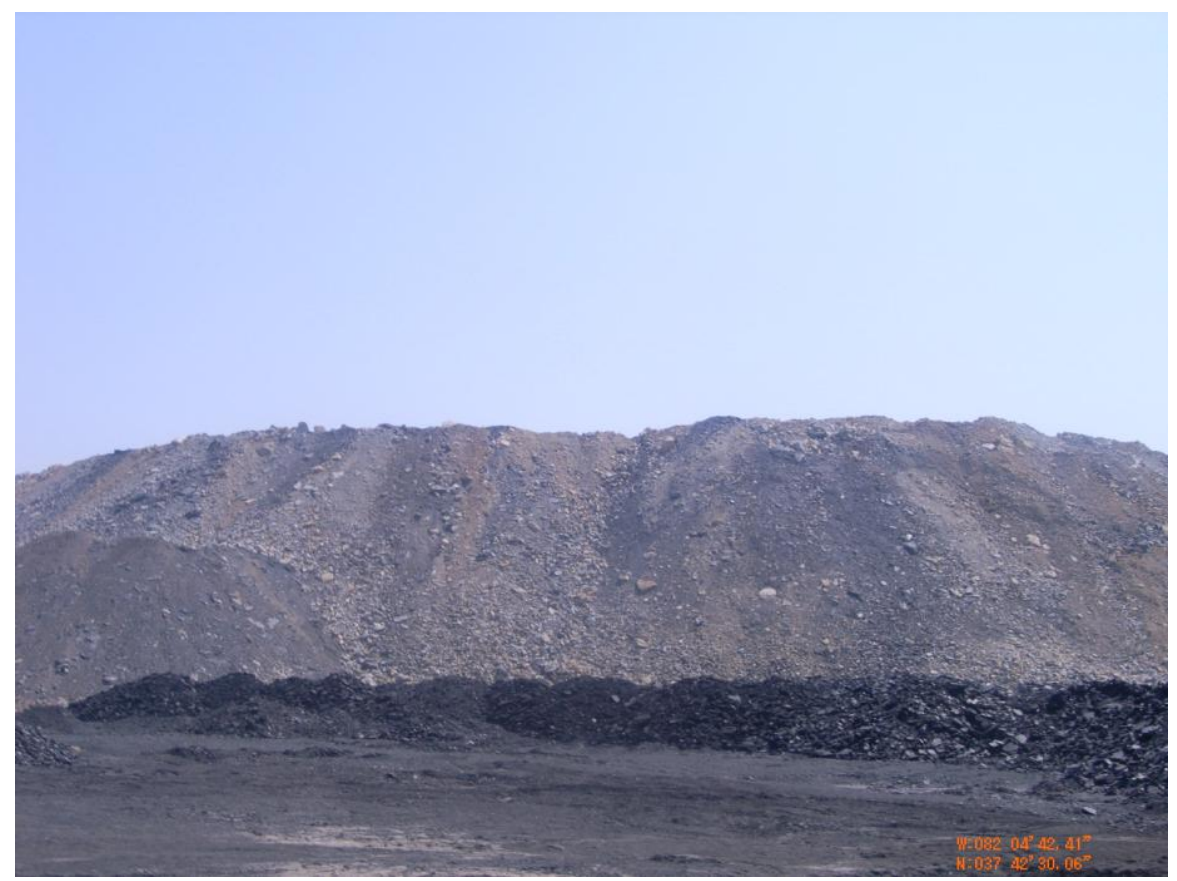

Figure 3.2: Waste rock material collected

\subsection{Soil Testing}

The material selected for this research was a gray crushed rock material retrieved from a surface mine site in Logan County, West Virginia. The samples were obtained prior to any leveling or compaction effort. The geotechnical material physical and engineering property tests were performed according the American Society for Testing and Materials (ASTM) standard test methods and included: Soil Classification-USCS (D-2487), Moisture content (D-2216), Sieve/hydrometer (D-422), Specific Gravity (D-854), Atterberg Limits (D-4318), Compaction (D-698), Hydraulic Conductivity (D-5856), and Direct Shear (D-3080). The tests performed are summarized in Table 3.1 below. 
Table 3.1: Soil Testing Standards

\begin{tabular}{|l|l|}
\hline \multicolumn{1}{|c|}{ Test Name } & \multicolumn{1}{c|}{ Test Standand } \\
\hline USCS Soil Classification & ASTM D-2487 \\
\hline Moisture Content & ASTM D-2216 \\
\hline Sieve/Hydrometer & ASTM D-422 \\
\hline Specific Gravity & ASTM D-854 \\
\hline Atterberg Limits & ASTM D-4318 \\
\hline CompactionPre & ASTM D-698 \\
\hline Hydraulic Conductivity & ASTM D-5856 \\
\hline Direct Shear & ASTM D-3080 \\
\hline
\end{tabular}

\subsection{Site Hydrology}

To fully classify the site before modeling, the hydrology of the site had to be fully defined. Defining the hydrology of the site was necessary to determine the inputs for later modeling. This process consisted of using precipitation data and runoff characteristics to determine what amount and at what rate water infiltrates into the fill.

\section{Precipitation}

Hydrologic information was obtained from the National Oceanic and Atmospheric Administration (2012). Archived daily precipitation data was found using an interactive map of the GHCN (Gloabal Historical Climatology Network) Daily precipitation data for the Logan, WV (46-5353) station. This was the closest station to the surface mine of interest. Daily precipitation totals were downloaded from January 1, 2001 - December 31, 2010. The data were compared to a previous study using 2010 precipitation data. Meek and O'dell (2012) used a total precipitation of 45.87 inches for 2010, which compared well to the value of 48.95 inches from NOAA. For each of these 10 years, precipitation over time was graphed. Figure 3.10 is the rainfall graph for the year 2001, which was used later for infiltration functions: 


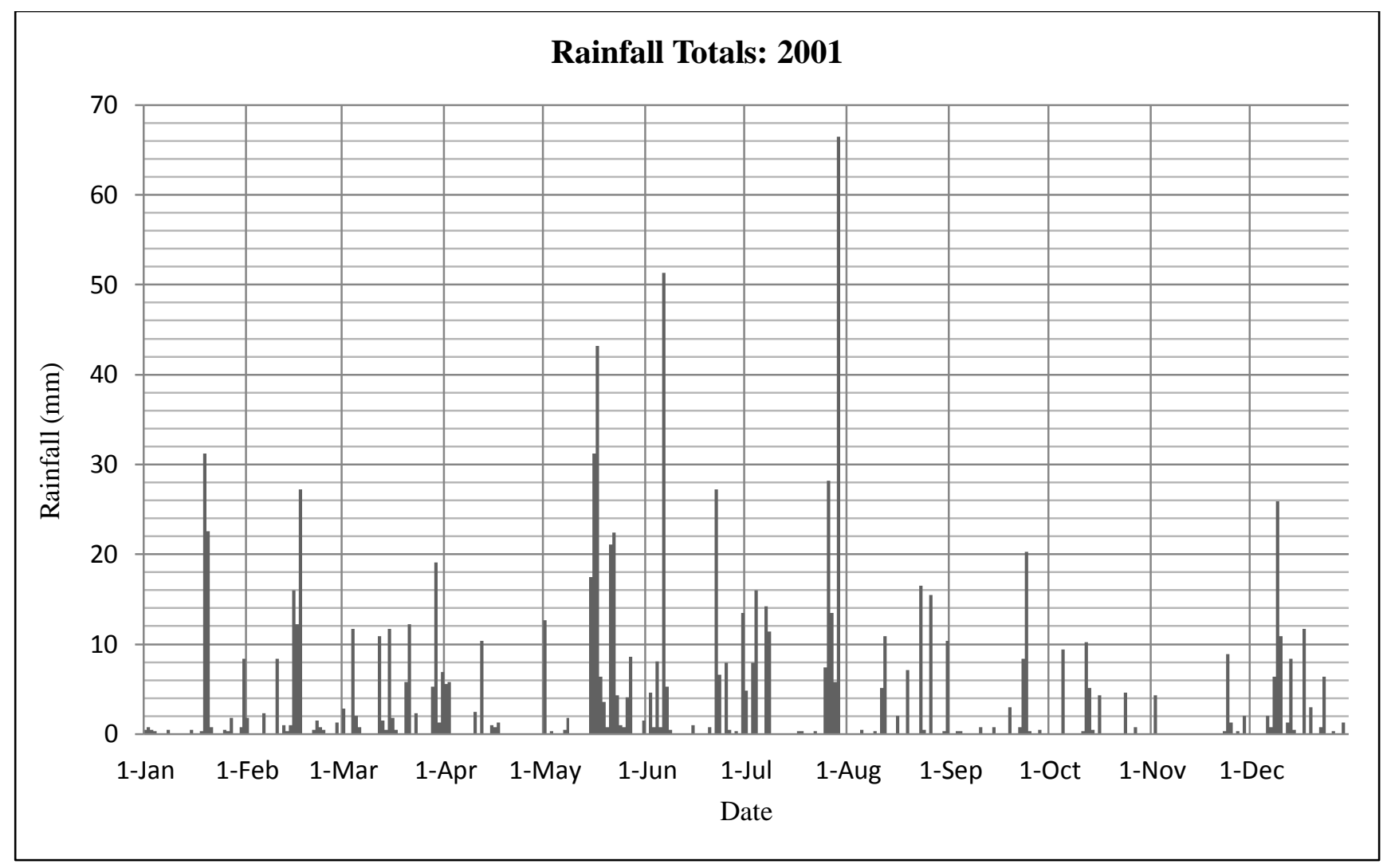

Figure 3.3: 2001 rainfall totals for Logan, WV

$\underline{\text { Infiltration from Storm Events }}$

Rainfall intensities for specific storm types (100-yr, 24-hr; 500-yr, 24-hr) were taken from the IDF (intensity-duration-frequency) table from NOAA's Precipitation Frequency Data Server (2012). This data was also taken from the Logan, WV station. For the transient condition, infiltration was determined as a function of time. This first step in developing this function was to find the infiltration function for different storm events. Frequencies of 2, 10, 25, 50, 100, and 500 years were analyzed for both $1 \mathrm{hr}$ and $24 \mathrm{hr}$ durations. These storms were modeled using the Horton infiltration capacity equation, which is shown in Equation 1 below:

where,

$$
f=f_{c}+\left(f_{0}-f_{c}\right) e^{-k t}
$$

$$
\begin{gathered}
f=\text { infiltration capacity }(\mathrm{in} / \mathrm{hr}) \\
f_{0}=\text { initial infiltration capacity }(\mathrm{in} / \mathrm{hr}) \\
f_{c}=\text { final capacity }(\mathrm{in} / \mathrm{hr}) \\
k=\text { empirical constant }\left(\mathrm{hr} \mathrm{r}^{-1}\right)
\end{gathered}
$$


Huber and Dickinson (1998) stated that the value of the k constant should be taken as 4.14/hr in the absence on field data. For this reason, 4.14/hr was used as the k value for modeling. The final infiltration capacity was taken as the saturated hydraulic conductivity. Hydraulic conductivity was chosen from a range values found from previous work done with waste rock tailings. These ranged from an unsaturated hydraulic conductivity of $1 \times 10^{-5} \mathrm{~m} / \mathrm{s}$ taken from a study by Abdelghani et al. (2009) to a saturated hydraulic conductivity of $1 \times 10^{-7} \mathrm{~m} / \mathrm{s}$ taken from Aubertin et al. (1996). These previously published values were chosen instead of the values determined from laboratory testing because they represented actual data used in practice. Laboratory testing calculated hydraulic conductivity based on optimum water content and compaction values, which are difficult to obtain in the field. Previously published values for hydraulic conductivity of waste rock tailings provided a more practical value to be used in numerical modeling. For each storm, the lowest value between the rainfall intensity and the unsaturated hydraulic conductivity of $1 \times 10^{-5} \mathrm{~m} / \mathrm{s}$ was used as the initial infiltration capacity. This was because the fastest that water could infiltrate was at the magnitude of the unsaturated hydraulic conductivity. Figure 3.11 below plots infiltration versus time for the $1 \mathrm{hr}$ storms:

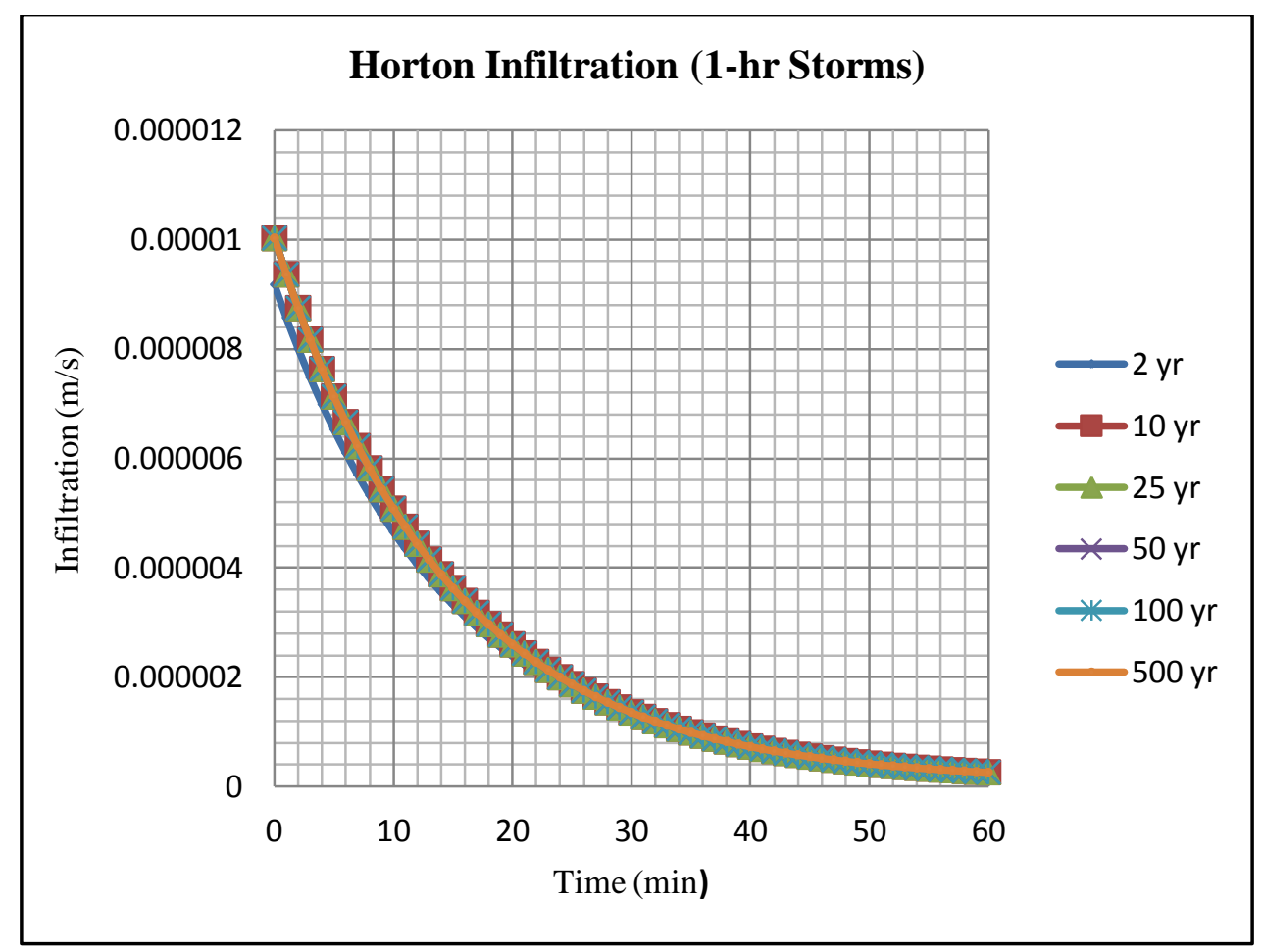

Figure 3.4: Horton infiltration function - 1 hour storms 
For the $1 \mathrm{hr}$ storms, the initial infiltration capacity was equal to the unsaturated hydraulic conductivity $\left(1 \times 10^{-5} \mathrm{~m} / \mathrm{s}\right)$ for all storms except the 2 year storm. This was because every storm other than the 2 year storm had a rainfall intensity of greater than the unsaturated hydraulic conductivity. As the soil became saturated, the rate at which the water was able to infiltrate decreased until all storms approached the same final infiltration capacity at the end of 1 hour. This final infiltration capacity was equal to the saturated hydraulic conductivity $\left(1 \times 10^{-7} \mathrm{~m} / \mathrm{s}\right)$.

Figure 3.12 below shows the plot of infiltration versus time for the 24 -hr storms:

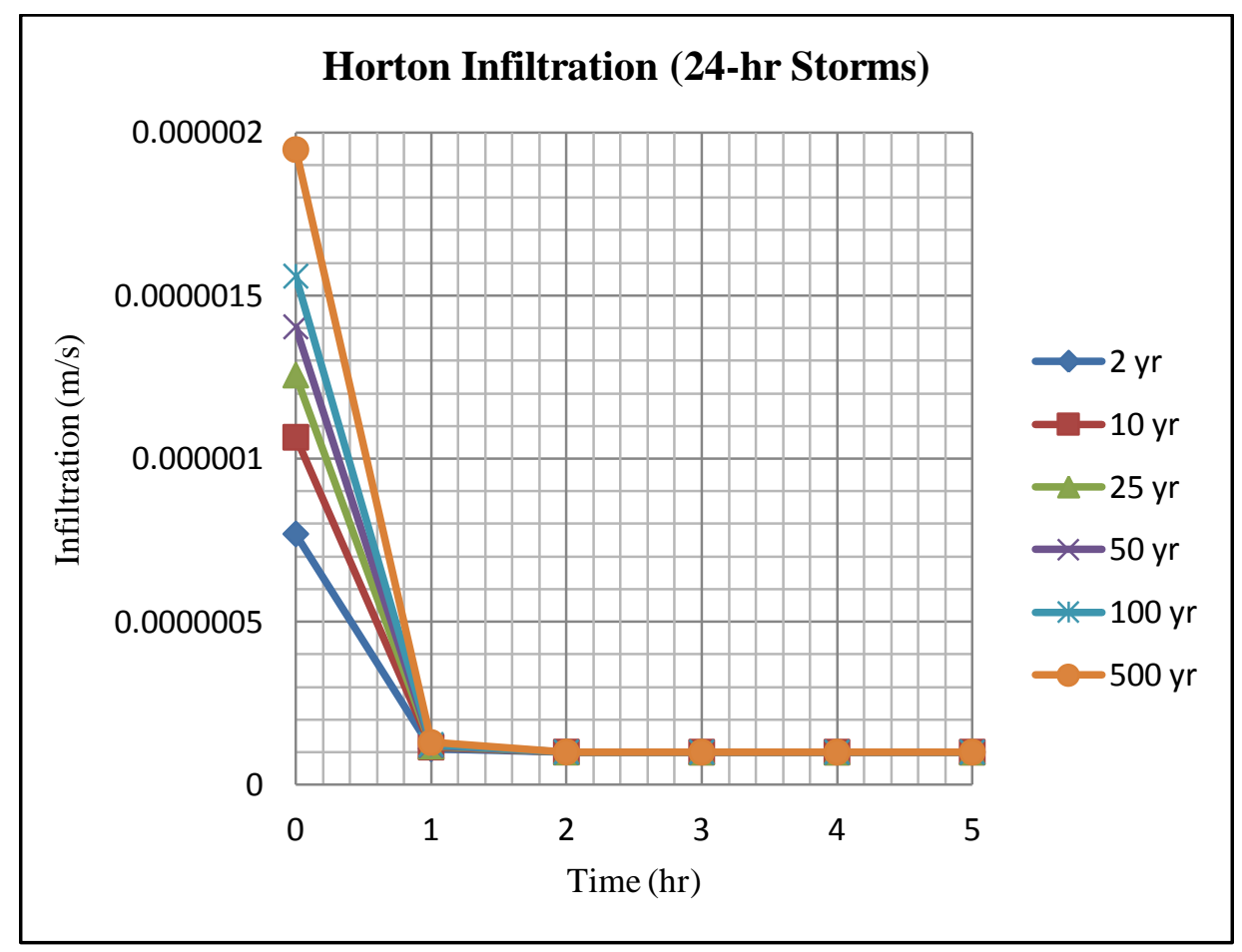

Figure 3.5: Horton infiltration function - 24 hour storms

For the 24-hr storms, all frequency storms had an initial infiltration capacity equal to the rainfall intensity. This was because each storm had a rainfall intensity less than the unsaturated hydraulic conductivity. Each storm reached the final infiltration capacity (saturated hydraulic conductivity) of the soil within $1 \mathrm{hr}$. 


\section{DATA ANALYSIS}

The following section discusses in detail all of the geotechnical tests performed on the soil. Data results are presented in tables for each test. For properties that were determined for multiple tests, statistics for standard deviation (s) and coefficient of variation (COV) are presented in order to give information on the precision of data from multiple tests.

\subsubsection{Soil Classification}

The material under inspection in this section was classified using the United Soil Classification System (USCS) - ASTM D-2487. After assessment, the material was classified as well graded sand (SW).

\subsubsection{Moisture Content}

Moisture content testing was performed according to ASTM standard test method D-2216-05. Moisture content was measured in the laboratory after the specimens acclimated to the indoor climate. Triplicate testing resulted in three moisture contents percentages of 2.84, 2.89, and 2.62 with an average moisture content of $2.78 \%$. The results are summarized in Tables 4.1 and 4.2 below.

Table 4.1: Moisture content test data

\begin{tabular}{|c|c|c|c|}
\hline Test Number & 1 & 2 & 3 \\
\hline Empty Container, $\mathbf{M}_{\mathrm{c},}(\mathrm{g})$ & 16.89 & 21.79 & 30.03 \\
\hline Container + Wet Sample, $\mathbf{M}_{\mathrm{cms}},(\mathrm{g})$ & 70.86 & 74.82 & 100.21 \\
\hline Container + Dry Sample, $\mathbf{M}_{\mathrm{cds}},(\mathrm{g})$ & 69.37 & 73.33 & 98.42 \\
\hline Moisture content w $(\%)$ & $\mathbf{2 . 8 4}$ & $\mathbf{2 . 8 9}$ & $\mathbf{2 . 6 2}$ \\
\hline
\end{tabular}

Table 4.2: Moisture content test statistics

\begin{tabular}{|l|r|}
\hline Average Moisture Content (\%): & $\mathbf{2 . 7 8}$ \\
\hline Sample Standard Deviation (s) & 0.145 \\
\hline Coefficient of Variation (COV) & 0.052 \\
\hline
\end{tabular}




\subsubsection{As Received Grain Size Distribution}

Sieve analysis was performed according to ASTM D 422-63. A duplicate test was performed to ensure accuracy in the data. For the first test the critical indices $(\mathrm{mm})$ were $\mathrm{D}_{90}=12, \mathrm{D}_{60}=2.7$, $\mathrm{D}_{50}=1.6, \mathrm{D}_{30}=0.55, \mathrm{D}_{25}=0.40$, and $\mathrm{D}_{10}=0.13(\mathrm{~mm})$. The uniformity coefficient $\left(\mathrm{C}_{\mathrm{u}}\right)$ was 20.77 and the coefficient of gradation $\left(\mathrm{C}_{\mathrm{c}}\right)$ was 0.86 . For the second test, the critical indices $(\mathrm{mm})$ were $\mathrm{D}_{90}=10.7, \mathrm{D}_{60}=3.0, \mathrm{D}_{50}=1.6, \mathrm{D}_{30}=0.55, \mathrm{D}_{25}=0.39$, and $\mathrm{D}_{10}=0.12$. The uniformity coefficient $\left(\mathrm{C}_{\mathrm{u}}\right)$ was 25.00 and the coefficient of gradation $\left(\mathrm{C}_{\mathrm{c}}\right)$ was 0.84 . This resulted in an average uniformity coefficient of $22.9 \%$ and an average coefficient of gradation of 0.85. The results are summarized in Tables 4.3 and 4.4 below.

\begin{tabular}{|c|c|c|}
\hline Critical Indices & Test 1 & Test 2 \\
\hline $\mathrm{D}_{90}$ & 12 & 10.7 \\
\hline$D_{60}$ & 2.7 & 3 \\
\hline $\mathrm{D}_{50}$ & 1.6 & 1.6 \\
\hline$D_{30}$ & 0.55 & 0.55 \\
\hline$D_{25}$ & 0.40 & 0.39 \\
\hline $\mathrm{D}_{10}$ & 0.13 & 0.12 \\
\hline Uniformity Coefficient, $C_{u}$ & 20.77 & 25.00 \\
\hline Coefficient of Gradation, $C_{c}$ & 0.86 & 0.84 \\
\hline
\end{tabular}

Table 4.4: Critical indices statistics

\begin{tabular}{|c|c|c|}
\hline & Uniformity Coefficient, $C_{\mathrm{u}}$ & Coefficient of Gradation, $\mathrm{C}_{\mathrm{c}}$ \\
\hline Average & 22.9 & 0.851 \\
\hline Sample Standard Deviation (s) & 2.992 & 0.015 \\
\hline Coefficient of Variation (COV) & 0.131 & 0.018 \\
\hline
\end{tabular}

A $152 \mathrm{H}$ hydrometer was used to analyze the grain size of the particles passing the No. 200 sieve. The data results are summarized in Table 4.5 below. 
Table 4.5: Hydrometer test results

\begin{tabular}{|c|c|c|c|c|c|c|c|c|}
\hline $\begin{array}{c}\text { Elapsed } \\
\text { Time, (T) } \\
\text { min }\end{array}$ & $\begin{array}{c}\text { Hydrometer } \\
\text { Reading }\end{array}$ & $\begin{array}{c}\text { Actual } \\
\text { Hydrometer } \\
\text { Reading, }\end{array}$ & $\begin{array}{c}\text { Temp, } \\
{ }^{\circ} \mathrm{C}\end{array}$ & $\mathrm{K}$ & $\mathrm{a}$ & $\begin{array}{c}\% \\
\text { Finer, } \\
\mathrm{P}\end{array}$ & $\begin{array}{c}\text { Effective } \\
\text { Depth, (L) } \\
\mathrm{cm}\end{array}$ & $\begin{array}{c}\text { Particle } \\
\text { Diameter, } \\
\text { (D) mm }\end{array}$ \\
\hline 2 & 60 & 60 & 22 & 0.01294 & 0.98 & 60.5 & 6.5 & 0.0233 \\
\hline 5 & 56 & 56 & 22 & 0.01294 & 0.98 & 56.4 & 7.1 & 0.0154 \\
\hline 15 & 46 & 46 & 22 & 0.01294 & 0.98 & 46.4 & 8.8 & 0.0099 \\
\hline 30 & 40 & 40 & 22 & 0.01294 & 0.98 & 40.3 & 9.7 & 0.0074 \\
\hline 60 & 36 & 36 & 22 & 0.01294 & 0.98 & 36.3 & 10.4 & 0.0054 \\
\hline 250 & 26 & 26 & 22 & 0.01294 & 0.98 & 26.2 & 12 & 0.0028 \\
\hline 1440 & 18 & 18 & 22 & 0.01294 & 0.98 & 18.1 & 13.3 & 0.0012 \\
\hline
\end{tabular}

Using the sieve analysis results along with a hydrometer analysis on particles passing the No. 200 sieve, grain size distributed was plotted. This graph can be seen in Figure 4.1 below.

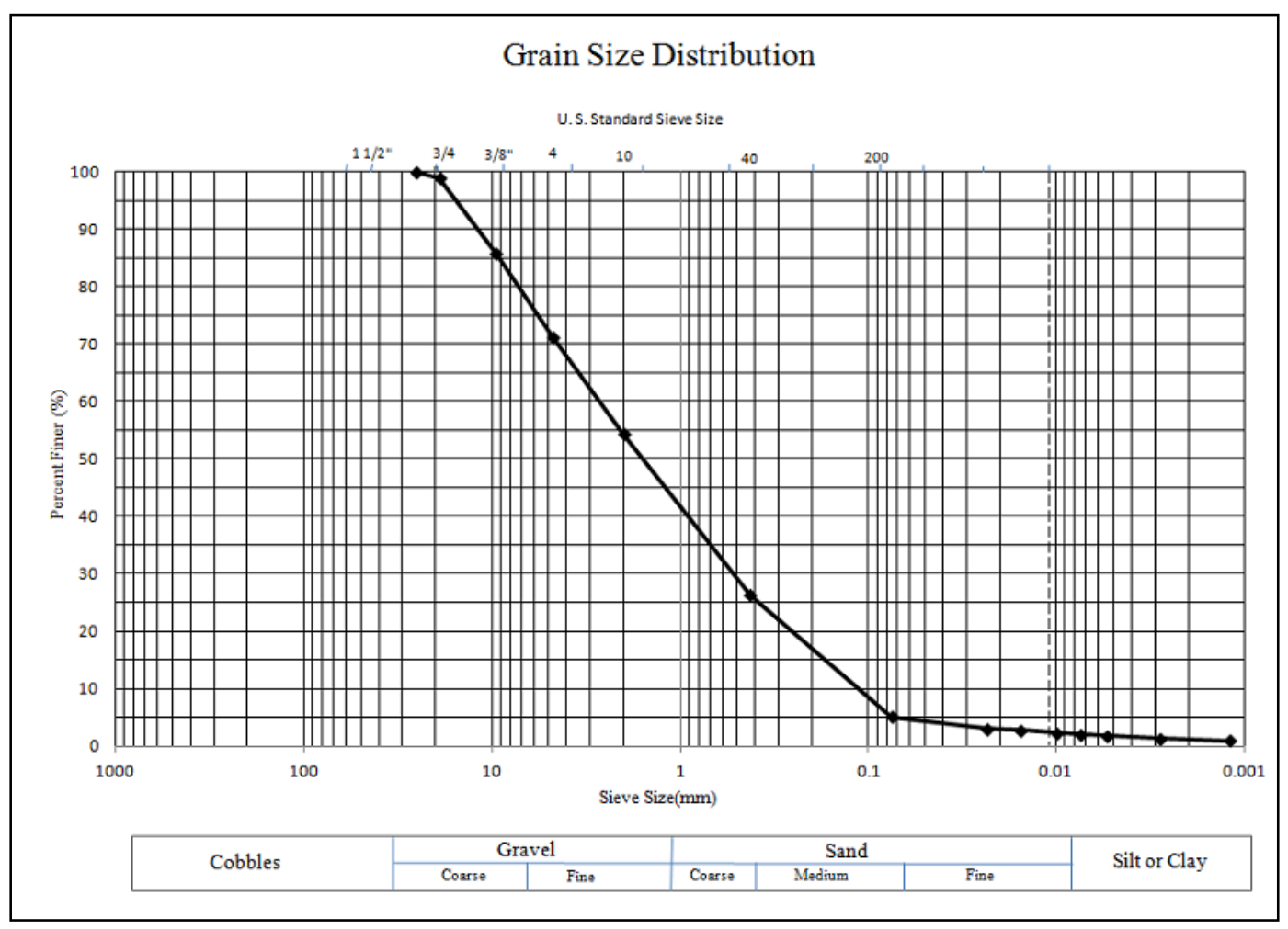

Figure 4.1: As received grain size distribution 


\subsubsection{Specific Gravity}

Specific gravity testing was performed according to ASTM Standard Test Method D-854. Six tests were performed. The specific gravity was found to be 2.69. The results are summarized in the Tables 4.6 and 4.7 below.

Table 4.6: Specific gravity test results

\begin{tabular}{|c|c|c|c|c|c|c|}
\hline Test Number & 1 & 2 & 3 & 4 & 5 & 6 \\
\hline Temperature, $\mathrm{T}\left({ }^{\circ} \mathrm{C}\right)$ & 22.00 & 22.00 & 22.00 & 22.00 & 22.00 & 22.00 \\
\hline Density of Water, $\rho_{\mathrm{w}}(\mathrm{g} / \mathrm{mL})$ & 0.99777 & 0.99777 & 0.99777 & 0.99777 & 0.99777 & 0.99777 \\
\hline Temperature Coefficient, $\mathrm{K}$ & 0.99957 & 0.99957 & 0.99957 & 0.99957 & 0.99957 & 0.99957 \\
\hline Volume of Pycnometer, $V_{p}(\mathrm{~mL})$ & 500.00 & 500.00 & 500.00 & 500.00 & 500.00 & 500.00 \\
\hline Wt. of Pycnometer, $\mathrm{M}_{\mathrm{p}}(\mathrm{g})$ & 167.27 & 169.04 & 160.62 & 159.74 & 152.74 & 154.85 \\
\hline Sample+Pycnomter+Water, $\mathrm{M}_{\mathrm{pws}, \mathrm{t}}(\mathrm{g})$ & 694.88 & 696.16 & 688.03 & 688.90 & 681.95 & 683.68 \\
\hline Pycnometer+Water, $\mathrm{M}_{\mathrm{pw}, \mathrm{t}}(\mathrm{g})$ & 663.42 & 666.03 & 657.71 & 657.82 & 650.84 & 653.13 \\
\hline Dry Sample Mass, $\mathrm{M}_{\mathrm{s}}(\mathrm{g})$ & 48.58 & 48.55 & 48.69 & 49.42 & 49.38 & 49.34 \\
\hline Wt. of Sample (g) & 50.00 & 50.00 & 50.00 & 50.00 & 50.00 & 50.00 \\
\hline Specific Gravity of soil solids, $\mathbf{G}_{t}$ & 2.84 & 2.64 & 2.65 & 2.69 & 2.70 & 2.63 \\
\hline Specific Gravity at Test Temp., $G_{t t}$ & 2.84 & 2.63 & 2.65 & 2.69 & 2.70 & 2.62 \\
\hline
\end{tabular}

Table 4.7: Specific gravity test statistics

\begin{tabular}{|l|c|}
\hline Average Specific Gravity, $\mathbf{G}_{\mathbf{t}}$ : & 2.69 \\
\hline Sample Standard Deviation for $\mathrm{G}_{\mathrm{t}} \mathrm{s}$ & 0.078 \\
\hline Coefficient of Variation for $\mathrm{G}_{\mathrm{t}}(\mathrm{COV})$ & 0.029 \\
\hline
\end{tabular}




\subsubsection{Atterberg Limits}

Atterberg limit tests included the plastic limit and liquid limit test. The tests were performed on the crushed rock material according to ASTM standard test method D-4318. Duplicate testing was performed in order to ensure accuracy in the data. For the first test, the liquid limit of the material was found to be 19.3 and the plastic limit was found to be 16.3 with a plasticity index of 3.1. The results are summarized in Tables 4.8 and 4.9 and Figure 4.2 below.

Table 4.8: Liquid limit test 1 results

\begin{tabular}{|l|c|c|c|}
\hline \multicolumn{1}{|c|}{ Test Number } & 1 & 5 & 3 \\
\hline Empty Container (g) & 18.80 & 30.28 & 16.90 \\
\hline Container + Wet Sample (g) & 32.55 & 45.46 & 35.71 \\
\hline Container + Dry Sample (g) & 30.25 & 43.01 & 33.00 \\
\hline Moisture content, w (\%) & 20.09 & 19.25 & 16.83 \\
\hline Weight of Water (g) & 2.30 & 2.45 & 2.71 \\
\hline Number of Blows: & 16.00 & 26.00 & 39.00 \\
\hline Liquid Limit: & $\mathbf{1 9 . 3}$ & & \\
\hline
\end{tabular}

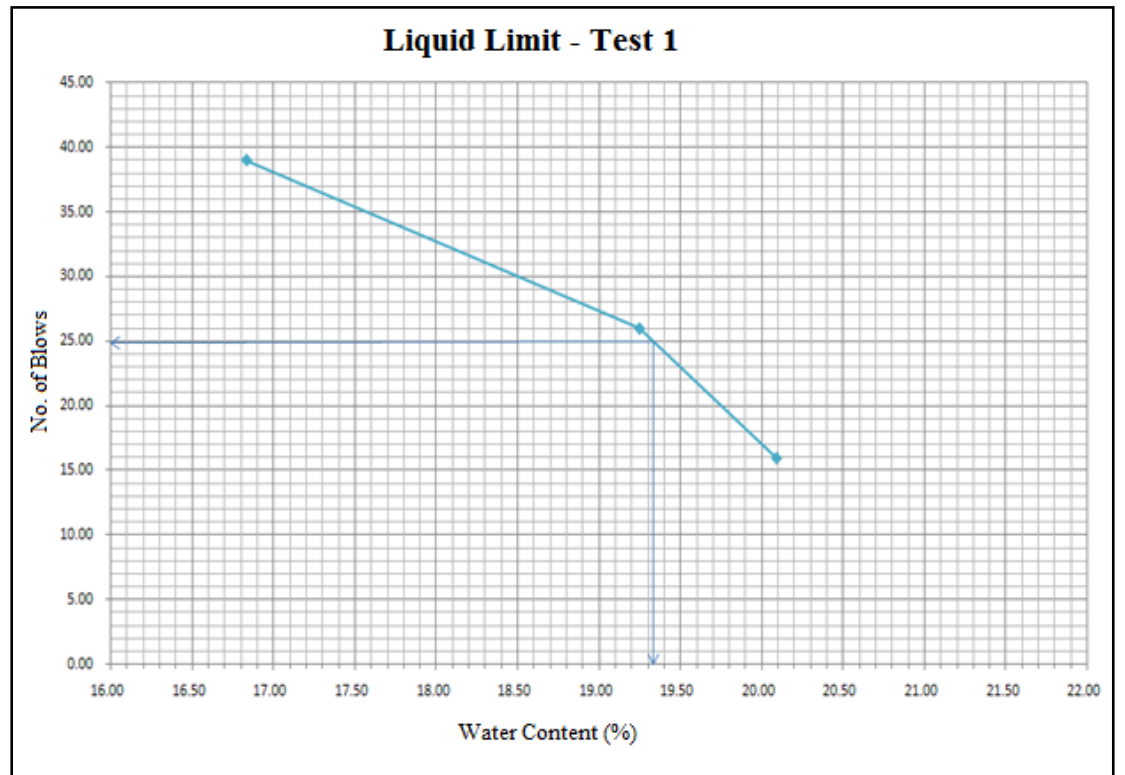

Figure 4.2: Plot of liquid limit test 1 
Table 4.9: Plastic limit test 1 results

\begin{tabular}{|l|c|c|c|}
\hline \multicolumn{1}{|c|}{ Test Number } & 2 & 4 & 6 \\
\hline Empty Container (g) & 17.40 & 30.46 & 16.90 \\
\hline Container + Wet Sample (g) & 20.10 & 36.29 & 20.30 \\
\hline Container + Dry Sample (g) & 19.71 & 35.51 & 19.82 \\
\hline Moisture content, w (\%) & $\mathbf{1 6 . 8 8}$ & $\mathbf{1 5 . 4 5}$ & $\mathbf{1 6 . 4 4}$ \\
\hline Weight of Water (g) & 0.39 & 0.78 & 0.48 \\
\hline Plastic Limit: & $\mathbf{1 6 . 3}$ & & \\
\hline Plasticity Index: & & & \\
\hline
\end{tabular}

For the second test, the liquid limit of the material was found to be 19.1 and the plastic limit was found to be 16.5 with a plasticity index of 2.6. The test results are presented in Tables 4.10 and 4.11 and Figure 4.3 below.

Table 4.10: Liquid limit test 2 results

\begin{tabular}{|l|c|c|c|c|}
\hline \multicolumn{1}{|c|}{ Test Number } & 1 & 3 & 5 & 7 \\
\hline Empty Container (g) & 18.80 & 16.90 & 30.28 & 17.45 \\
\hline Container + Wet Sample (g) & 30.65 & 32.69 & 39.02 & 32.05 \\
\hline Container + Dry Sample (g) & 28.66 & 30.16 & 37.66 & 29.53 \\
\hline Moisture content w (\%) & $\mathbf{2 0 . 1 8}$ & $\mathbf{1 9 . 0 8}$ & $\mathbf{1 8 . 4 3}$ & $\mathbf{2 0 . 8 6}$ \\
\hline Weight of Water (g) & 1.99 & 2.53 & 1.36 & 2.52 \\
\hline Number of Blows: & 17.00 & 25.00 & 32.00 & 15.00 \\
\hline Liquid Limit & & & & \\
\hline
\end{tabular}




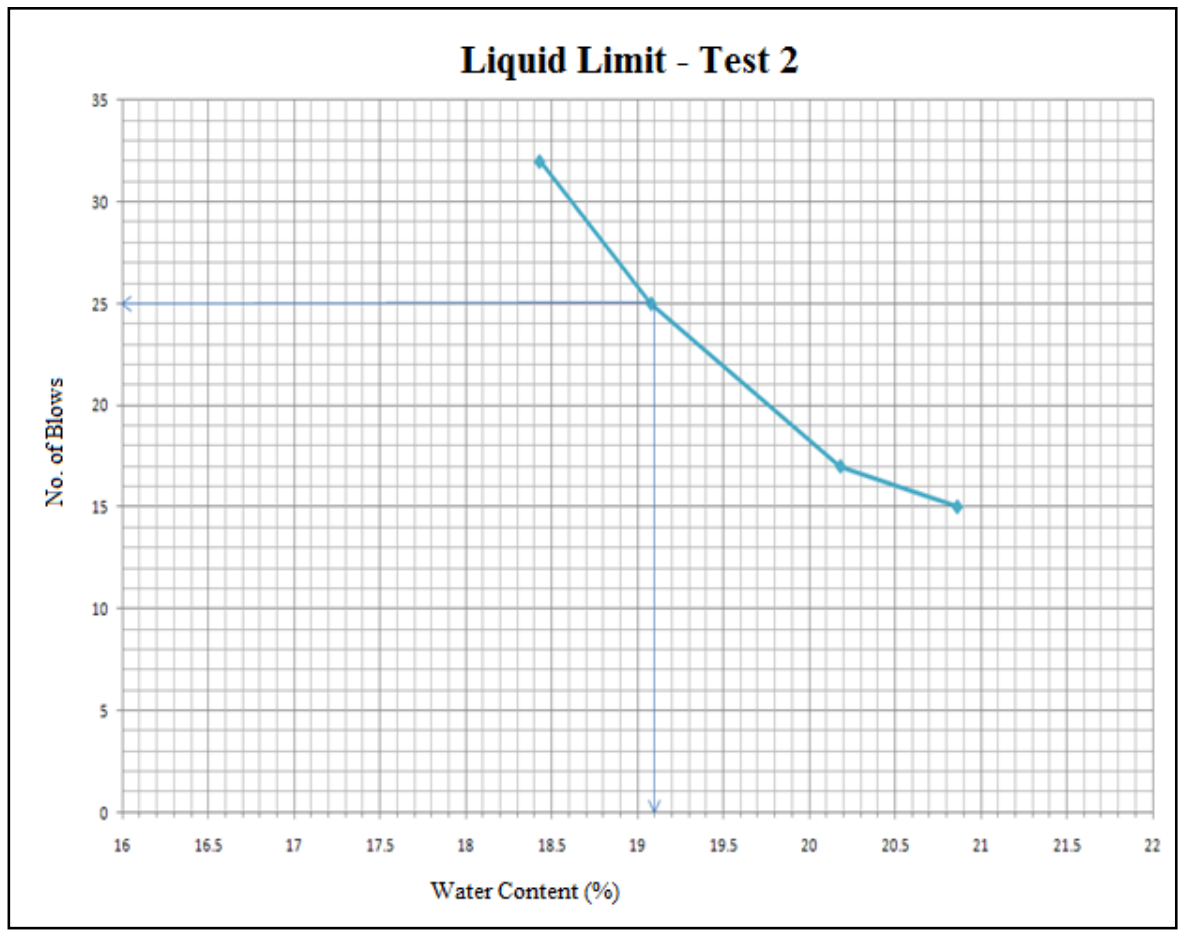

Figure 4.3: Plot of liquid limit test 2

Table 4.11: Plastic limit test 2 results

\begin{tabular}{|c|c|c|c|c|}
\hline Test Number & 2 & 4 & 6 & 8 \\
\hline Empty Container (g) & 17.40 & 30.46 & 16.90 & 16.87 \\
\hline Container + Wet Sample $(\mathrm{g})$ & 18.82 & 35.48 & 18.44 & 19.61 \\
\hline Container + Dry Sample (g) & 18.62 & 34.74 & 18.22 & 19.24 \\
\hline Moisture content w (\%) & 16.39 & 17.29 & 16.67 & 15.61 \\
\hline Weight of Water $(\mathrm{g})$ & 0.20 & 0.74 & 0.22 & 0.37 \\
\hline Plastic Limit: & 16.5 & & & \\
\hline Plasticity Index: & 2.6 & & & \\
\hline
\end{tabular}


The results for the liquid limit and plasticity index are summarized below in Table 4.12 with statistics.

Table 4.12: Atterberg limit test statistics

\begin{tabular}{|c|c|c|}
\hline & Liquid Limit (\%) & Plasticity Index \\
\hline Average & 19.2 & 2.85 \\
\hline Sample Standard Deviation (s) & 0.141 & 0.354 \\
\hline Coefficient of Variation (COV) & 0.02 & 0.125 \\
\hline
\end{tabular}

\subsubsection{Compaction}

Compaction testing was performed to find the maximum dry density of the gray crushed stone overburden material at three predetermined compaction energies. These energies were Standard Proctor $\left(592.5 \mathrm{~kJ} / \mathrm{m}^{3}\right), 34 \%$ of Standard Proctor $\left(203.6 \mathrm{~kJ} / \mathrm{m}^{3}\right)$, and $11 \%$ of Standard Proctor $\left(67.85 \mathrm{~kJ} / \mathrm{m}^{3}\right)$.

Compaction tests were first run at a Standard Proctor compaction effort (energy applied $=592.5$ $\mathrm{kJ} / \mathrm{m}^{3}$ ). Four water contents were tested. The water contents were calculated to be $4.12 \%$, $9.94 \%, 11.54 \%$, and $12.86 \%$. The optimum dry density of the material was found to be 18.75 $\mathrm{kN} / \mathrm{m}^{3}$ at a water content of $10.75 \%$.

Compaction tests where then run at a compaction effort of 34\% of Standard Proctor (energy applied $=203.6 \mathrm{~kJ} / \mathrm{m}^{3}$ ). The test applied 12 blows of a 5 pound compaction hammer to 2 layers of material in a typical compaction mold. Seven water contents were tested. The water contents were calculated to be $7.45 \%, 9.57 \%, 11.20 \%, 12.73 \%, 12.85 \%, 15.73 \%$, and $17.97 \%$. The optimum dry density of the material was found to be $18.1 \mathrm{kN} / \mathrm{m}^{3}$ at a water content of $14.5 \%$.

Compaction tests were lastly run at a compaction effort of $11 \%$ of Standard Proctor (energy applied $=67.85 \mathrm{~kJ} / \mathrm{m}^{3}$ ). The test applied 4 blows of a 5 pound compaction hammer to 2 layers of material in a typical compaction mold. Seven water contents were tested. The water contents were calculated to be $4.36 \%, 9.78 \%, 11.60 \%, 11.65 \%, 15.47 \%, 16.89 \%$, and $17.45 \%$. The optimum dry density of the material was found to be $17.6 \mathrm{kN} / \mathrm{m}^{3}$ at a water content of $16.89 \%$. 
The minimum dry density was found to be $14.9 \mathrm{kN} / \mathrm{m}^{3}$ at a corresponding water content of $9.75 \%$. Figure 4.4 below shows a plot of all of three compaction energies.

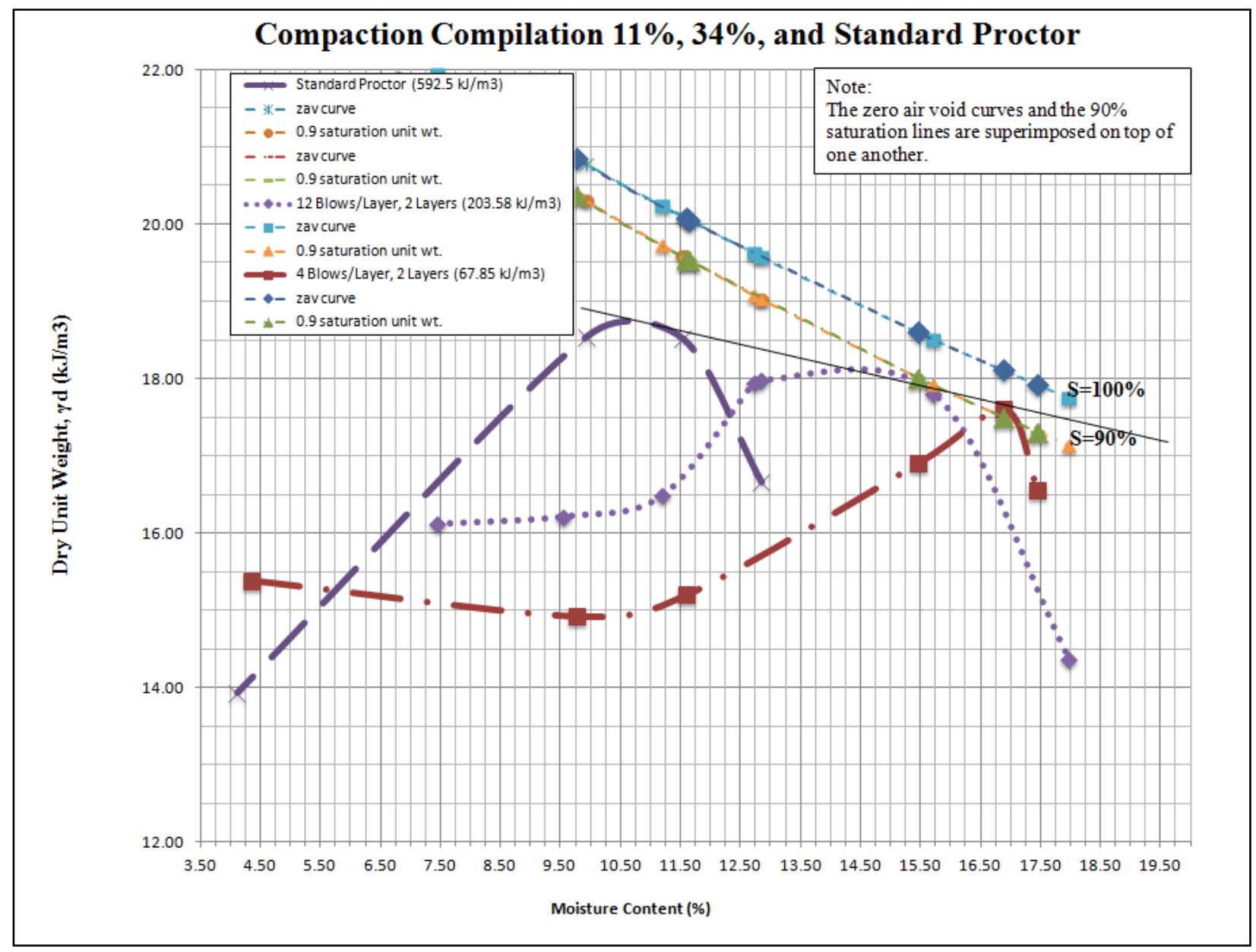

Figure 4.4: Compaction compilation

\subsubsection{Direct Shear}

The strength testing phase was organized into three different test specimens with predetermined compaction energies which each had unique void ratios. The compaction energies were at a Standard Proctor $\left(592.5 \mathrm{~kJ} / \mathrm{m}^{3}\right), 34 \%$ of Standard Proctor $\left(203.6 \mathrm{~kJ} / \mathrm{m}^{3}\right)$, and $11 \%$ of Standard Proctor $\left(67.85 \mathrm{~kJ} / \mathrm{m}^{3}\right)$. The specimens were prepared to target the optimum dry density for their respective compaction energies. Each compacted specimen was extruded approximately one third the length of the compaction mold. The three layers were captured in a direct shear specimen ring. Direct shearing tests were performed on each ring specimen. The stress 
conditions for consolidation were found by multiplying the optimum dry density of the crushed rock material by the depth of the valley fill profile shown below in Figure 4.5. The profile was taken from the WVDEP (2007) permit file for the mine site.

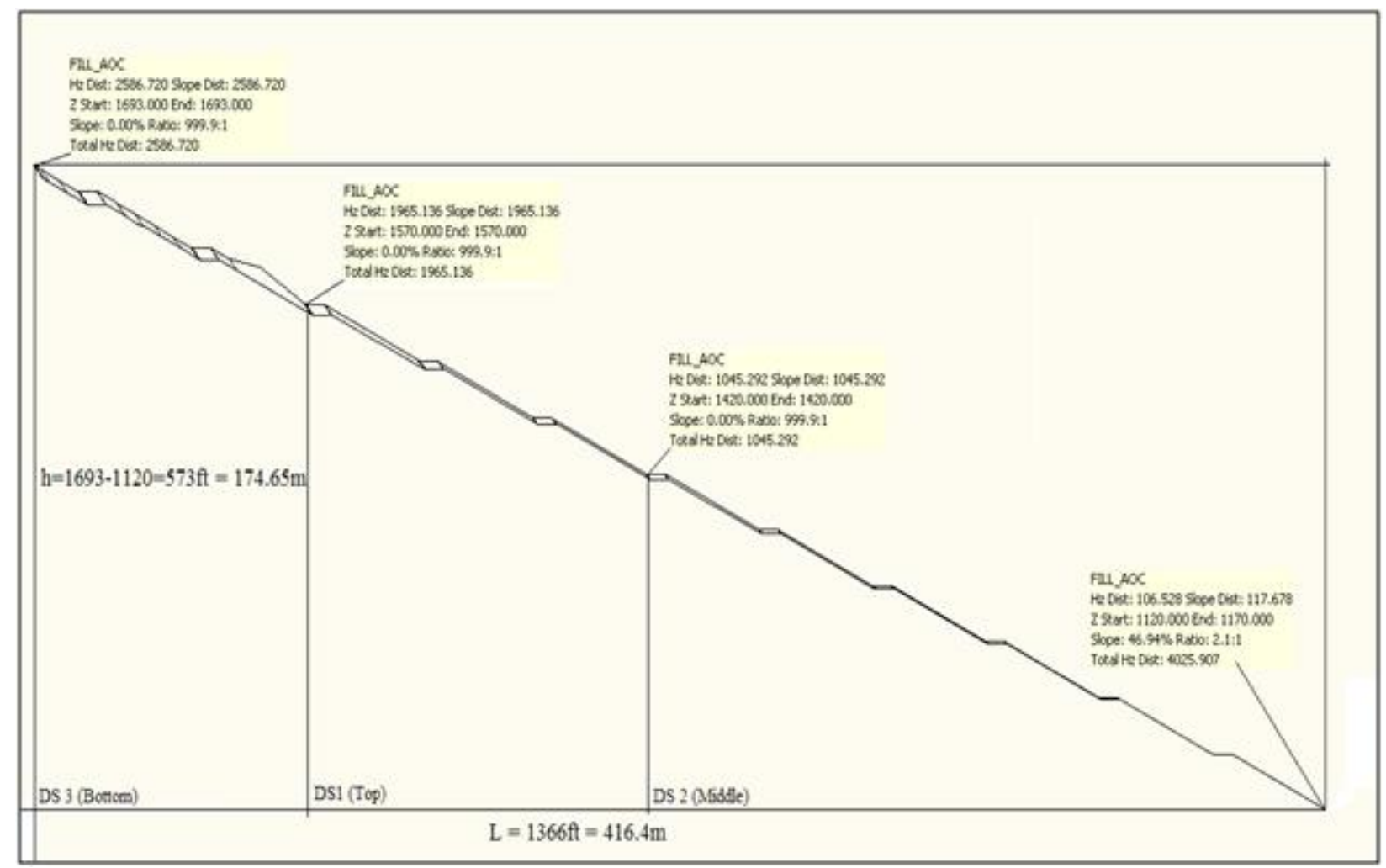

Figure 4.5: Valley fill profile used for direct shear tests

It was determined that an additional point could be assumed on the Mohr-Coulomb failure envelope at the origin $(0 \mathrm{kPa}, 0 \mathrm{kPa})$ since the material was classified as a well graded sand and would have little cohesion. The testing was performed at a saturated condition. An apparent cohesion resulted from graphing a best fit line to the data points. The apparent cohesion is understood to be the result of the creation of a negative pore pressure in the specimen during the shearing phase of the testing. The testing was performed on a GeoJac direct shear testing device using ASTM Standard D-3080. The software used to reduce the data was DigiShear.

Plots of shear stress versus normal stress for each of the three compaction energies were used to determine the values for cohesion (c, $\mathrm{kPa}$ ) and friction angle ( $\Phi$, degrees). At Standard Proctor compaction energy, cohesion was found to be 28.885 and friction angle was found to be 27.14. 
At $34 \%$ of Standard Proctor compaction energy, cohesion was found to be 61.64 and friction angle was found to be 22.77. At $11 \%$ of Standard Proctor compaction energy, cohesion was found to be 18.518 and friction angle was found to be 25.112 .

\section{Standard Proctor}

The consolidation stress conditions were at a normal stress of $1784.26 \mathrm{kPa}$ and $2676.40 \mathrm{kPa}$. The maximum shear stresses that occurred during the testing were $1029.95 \mathrm{kPa}$, and 1342.94 $\mathrm{kPa}$, respectively. The data are summarized in Table 4.13 and Figure 4.6 below.

Table 4.13: Direct shear test data-Standard Proctor

\begin{tabular}{|c|c|c|c|}
\hline Specimen Number & Max Shear Stress (ksf) & Max Shear Stress(psf) & Normal Stress (psf) \\
\hline 1 & 28.044 & 28044 & 55890 \\
\hline 2 & 21.508 & 21508 & 37260 \\
\hline 3 & 0 & 0 & 0 \\
\hline Specimen Number & Max Shear Stress $(\mathbf{k P a})$ & Normal Stress (kPa) & \\
\hline 1 & 1342.94 & 2676.40 & \\
\hline 2 & 1029.95 & 1784.26 & \\
\hline 3 & 0 & 0 & \\
\hline $\mathrm{m}=$ & 0.5126 & $\mathrm{~m}=$ & 0.525 \\
\hline$\phi_{\text {best fit }}($ degrees $)=$ & 27.14 & $\phi_{\mathrm{c}^{\prime}=0}($ degrees $)=$ & 27.70 \\
\hline$c^{\prime}(p s f)=$ & 602.57 & $c^{\prime}(\mathrm{kPa})=$ & 0.0 \\
\hline$c^{\prime}(\mathrm{kPa})=$ & 28.86 & & \\
\hline
\end{tabular}




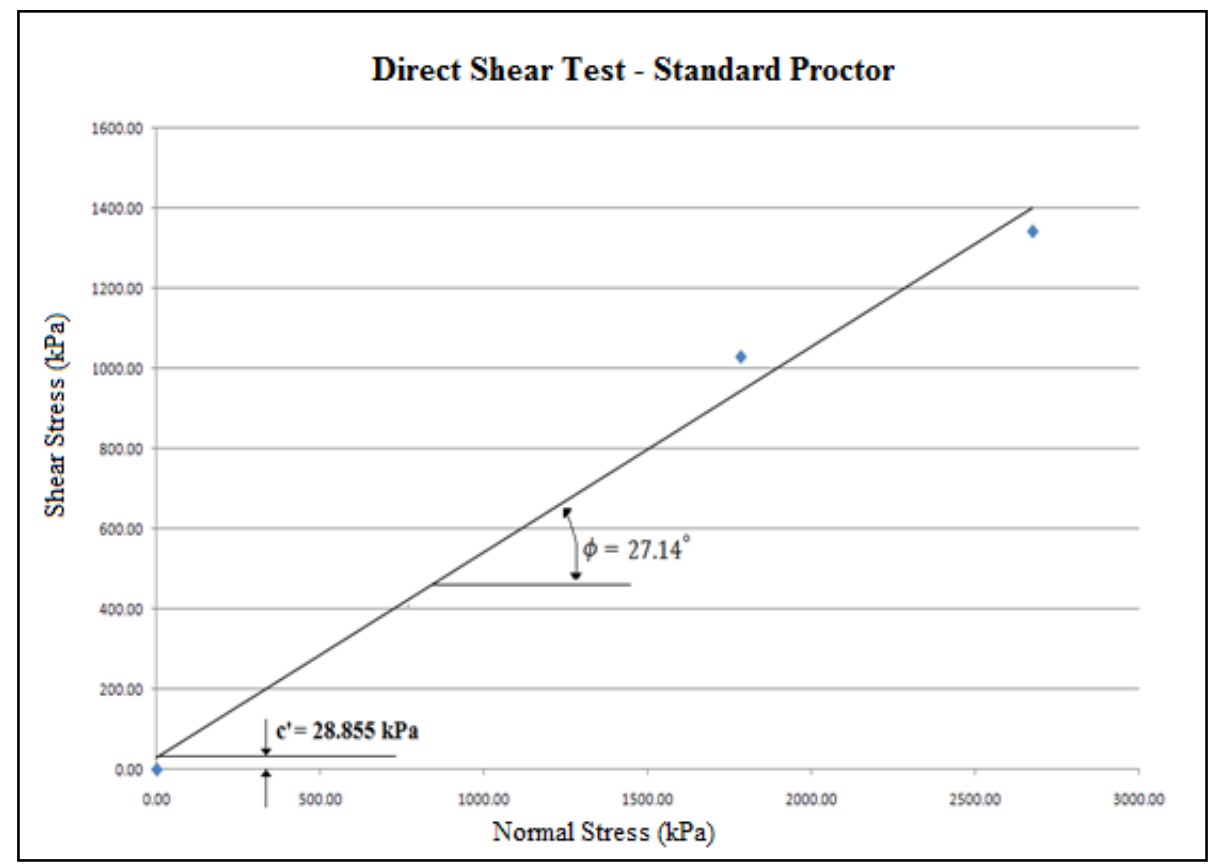

Figure 4.6: Direct shear test - Standard Proctor

\section{4\% of Standard Proctor}

The consolidation stress conditions were at normal stresses of $600 \mathrm{kPa}, 1200 \mathrm{kPa}$, and $2500 \mathrm{kPa}$ for the top, middle, and bottom layers, respectively. The maximum shear stresses that occurred during the testing were $365.71 \mathrm{kPa}, 607.73 \mathrm{kPa}$, and $1078.41 \mathrm{kPa}$, respectively. The data are summarized in Table 4.14 and Figure 4.7 below.

Table 4.14: Direct shear test data-34\% of Standard Proctor

\begin{tabular}{|r|c|c|c|}
\hline Specimen Number & Max Shear Stress (ksf) & Max Shear Stress(psf) & Normal Stress (psf) \\
\hline 1 & 7.64 & 7637 & 12531 \\
\hline 2 & 12.69 & 12691 & 25062 \\
\hline 3 & 22.52 & 22520 & 52213 \\
\hline 4 & 0 & 0 & 0 \\
\hline Specimen Number & Max Shear Stress(kPa) & Normal Stress (kPa) & \\
\hline 1 & 365.71 & 600.07 & \\
\hline 2 & 607.73 & 1200.14 & \\
\hline 3 & 1078.41 & 2500.32 & 0.4527 \\
\hline 4 & 0 & 0 & 24.36 \\
\hline$\phi_{\text {best fit }}($ degrees $)=$ & 0.4198 & $\phi_{c^{\prime}=0}{ }^{\prime}($ degrees $)=$ & \\
\hline$c^{\prime}(k s f)=$ & 22.77 & $c^{\prime}(k P a)=$ & \\
\hline$c^{\prime}(k P a)=$ & 1287.42 & & \\
\hline
\end{tabular}




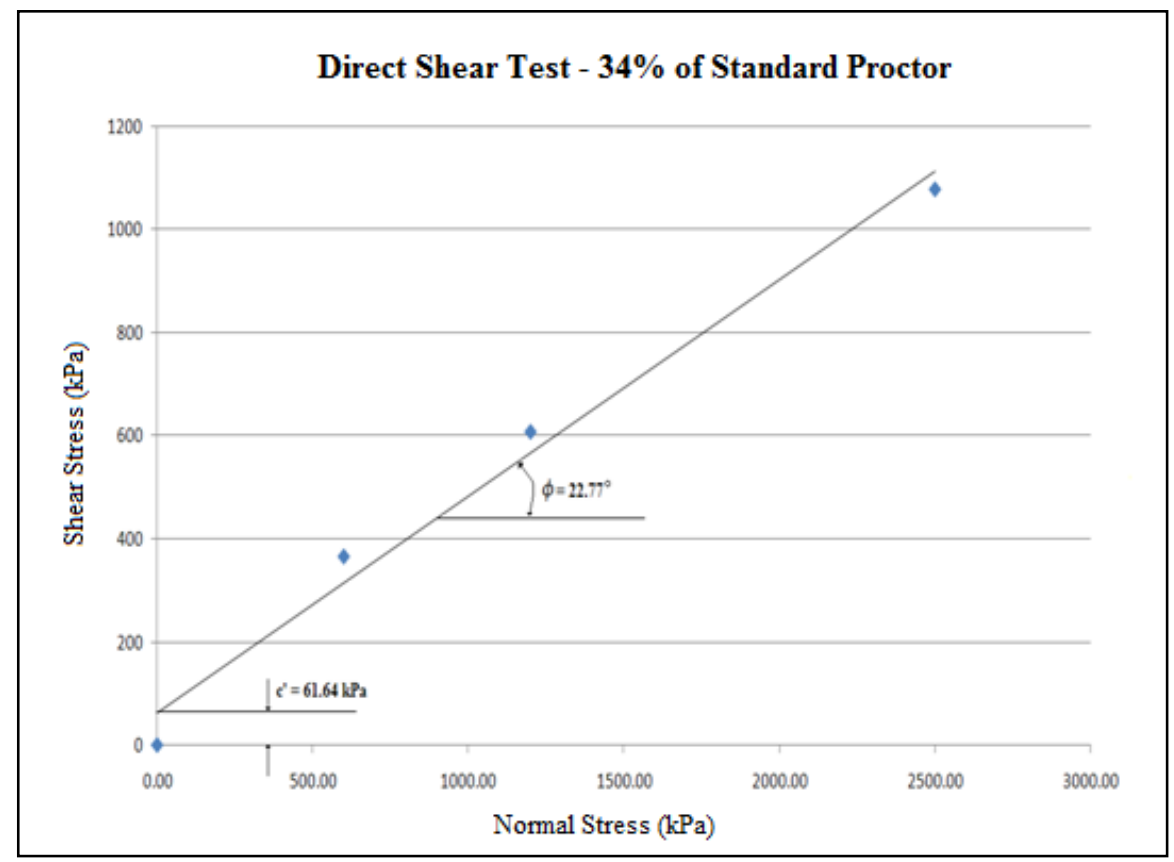

Figure 4.7: Direct shear test - 34\% of Standard Proctor

\section{1\% of Standard Proctor}

The consolidation stress conditions were at normal stresses of $600 \mathrm{kPa}, 1200 \mathrm{kPa}$, and $2500 \mathrm{kPa}$ for the top, middle, and bottom layers, respectively. The maximum shear stresses that occurred during the testing were $314.19 \mathrm{kPa}, 595.62 \mathrm{kPa}$, and $1180.03 \mathrm{kPa}$, respectively. The data are summarized in Table 4.15 and Figure 4.8 below.

Table 4.15: Direct shear test data - 11\% of Standard Proctor

\begin{tabular}{|c|c|c|c|}
\hline Specimen Number & Max Shear Stress (ksf) & Max Shear Stress(psf) & Normal Stress (psf) \\
\hline 1 & 6.561 & 6561 & 12531 \\
\hline 2 & 12.438 & 12438 & 25062 \\
\hline 3 & 24.642 & 24642 & 52213 \\
\hline 4 & 0 & 0 & 0 \\
\hline Specimen Number & Max Shear Stress(kPa) & Normal Stress (kPa) & \\
\hline 1 & 314.19 & 600 & \\
\hline 2 & 595.62 & 1200 & \\
\hline 3 & 1180.03 & 2500 & \\
\hline 4 & 0 & 0 & \\
\hline $\mathrm{m}=$ & 0.4687 & $\phi_{c^{\prime}=0}^{\prime}\left(\right.$ degrees $^{\prime}=$ & 25.576 \\
\hline$\phi_{\text {best fit }}($ degrees $)=$ & 25.112 & $\mathrm{c}^{\prime}(\mathrm{kPa})=$ & 0.0 \\
\hline $\mathrm{c}^{\prime}(\mathrm{ksf})=$ & 386.756 & & \\
\hline $\mathrm{c}^{\prime}(\mathrm{kPa})=$ & 18.518 & & \\
\hline & & & \\
\hline
\end{tabular}




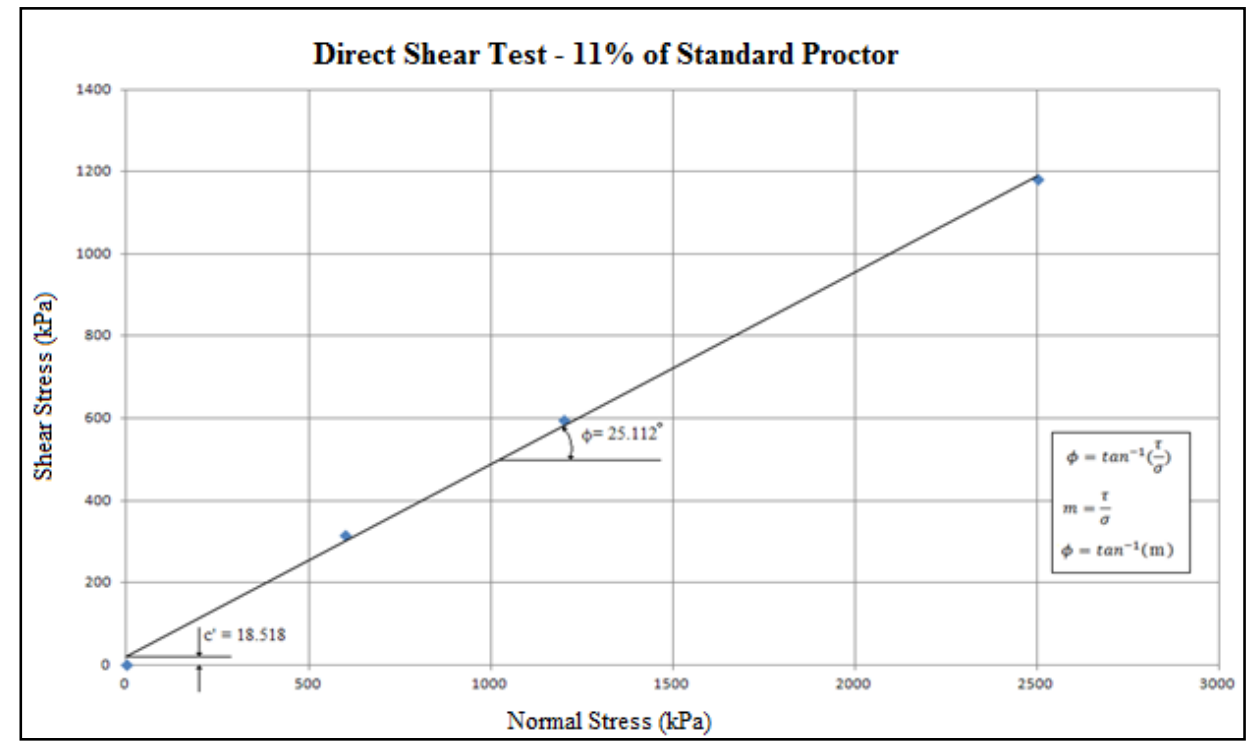

Figure 4.8: Direct shear test - 11\% of Standard Proctor

\subsubsection{Hydraulic Conductivity}

Hydraulic conductivity testing was performed on samples at each of the three compaction efforts. The objective of the testing was to determine the expected field hydraulic conductivity in order to better understand the rate at which water would permeate through the material under inspection. The hydraulic conductivity was determined after the data had become stable. In these cases, the average of the last five data points was taken to be the hydraulic conductivity of the specimens.

Testing was first performed on a specimen at Standard Proctor compaction effort $\left(592.5 \mathrm{~kJ} / \mathrm{m}^{3}\right)$. The target dry density was at optimum for the high compaction effort test data. The optimum dry density for the high compaction effort specimen was $18.75 \mathrm{kN} / \mathrm{m}^{3}$. Triplicate testing was performed to ensure accuracy. The dry densities for tests 1,2 , and 3 were $18.14 \mathrm{kN} / \mathrm{m}^{3}, 18.15$ $\mathrm{kN} / \mathrm{m}^{3}$, and $18.30 \mathrm{kN} / \mathrm{m}^{3}$ respectively. The average hydraulic conductivity $(\mathrm{m} / \mathrm{s})$ for each test was found to be was found to be $1.14 \times 10^{-9}, 5.81 \times 10^{-10}$, and $1.82 \times 10^{-9}$. The results are summarized in Tables 4.16 and 4.17 and plotted in Figure 4.9 below. 
Table 4.16: Hydraulic conductivity results - Standard Proctor

\begin{tabular}{|c|c|c|c|}
\hline Test & 1 & 2 & 3 \\
\hline Average Hydraulic Conductivity (m/s) & $1.14 \mathrm{E}-09$ & $5.81 \mathrm{E}-10$ & $1.82 \mathrm{E}-09$ \\
\hline Sample Standard Deviation $(\mathrm{s})$ & $8.33 \mathrm{E}-11$ & $1.41 \mathrm{E}-10$ & $1.13 \mathrm{E}-10$ \\
\hline Coefficient of Variation $(\mathrm{COV})$ & 0.073 & 0.243 & 0.062 \\
\hline
\end{tabular}

Table 4.17: Hydraulic conductivity statistics - Standard Proctor

\begin{tabular}{|c|c|}
\hline Average Hydraulic Conductivity from 3 Tests (m/s): & $\mathbf{1 . 1 8 E - 0 9}$ \\
\hline Sample Standard Deviation (s) & $6.20 \mathrm{E}-10$ \\
\hline Coefficient of Variation (COV) & 0.314 \\
\hline
\end{tabular}

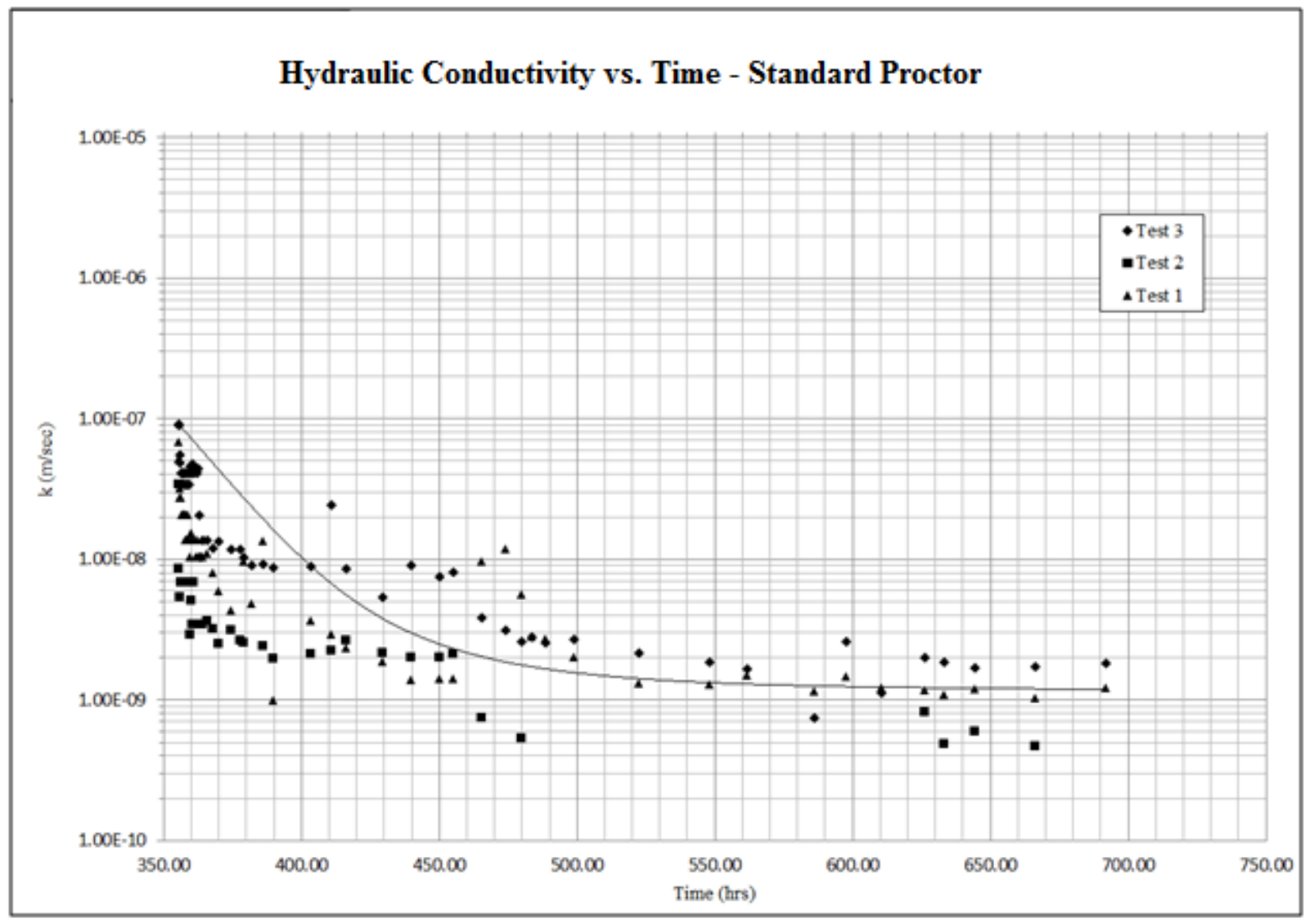

Figure 4.9: Hydraulic conductivity - Standard Proctor

Hydraulic conductivity testing was next performed on specimen at $34 \%$ of standard proctor compaction effort $\left(203.6 \mathrm{~kJ} / \mathrm{m}^{3}\right)$. The target dry density was at optimum for the medium 
compaction effort test data. The optimum dry density for the medium compaction effort specimen was $18.1 \mathrm{kN} / \mathrm{m}^{3}$. Triplicate testing was performed to ensure accuracy. The dry densities for tests 1,2 , and 3 were $16.32 \mathrm{kN} / \mathrm{m}^{3}, 16.44 \mathrm{kN} / \mathrm{m}^{3}$, and $17.61 \mathrm{kN} / \mathrm{m}^{3}$ respectively. The average hydraulic conductivity $(\mathrm{m} / \mathrm{s})$ for each test was found to be was found to be $2.02 \times 10^{-9}$, $1.69 \times 10^{-9}$, and $3.31 \times 10^{-9}$. The results are summarized in Tables 4.18 and 4.19 and plotted in Figure 4.10 below.

Table 4.18: Hydraulic conductivity results $-34 \%$ of Standard Proctor

\begin{tabular}{|c|c|c|c|}
\hline Test & 1 & 2 & 3 \\
\hline Average Hydraulic Conductivity (m/s) & $2.02 \mathrm{E}-09$ & $1.69 \mathrm{E}-09$ & $3.31 \mathrm{E}-09$ \\
\hline Sample Standard Deviation $(\mathrm{s})$ & $1.84 \mathrm{E}-10$ & $3.52 \mathrm{E}-10$ & $2.30 \mathrm{E}-10$ \\
\hline Coefficient of Variation $(\mathrm{COV})$ & 0.09 & 0.208 & 0.069 \\
\hline
\end{tabular}

Table 4.19: Hydraulic conductivity statistics $-34 \%$ of Standard Proctor

\begin{tabular}{|c|c|}
\hline Average Hydraulic Conductivity from 3 Tests (m/s): & $\mathbf{2 . 3 1 E - 0 9}$ \\
\hline Sample Standard Deviation (s) & $8.58 \mathrm{E}-10$ \\
\hline Coefficient of Variation (COV) & 0.544 \\
\hline
\end{tabular}




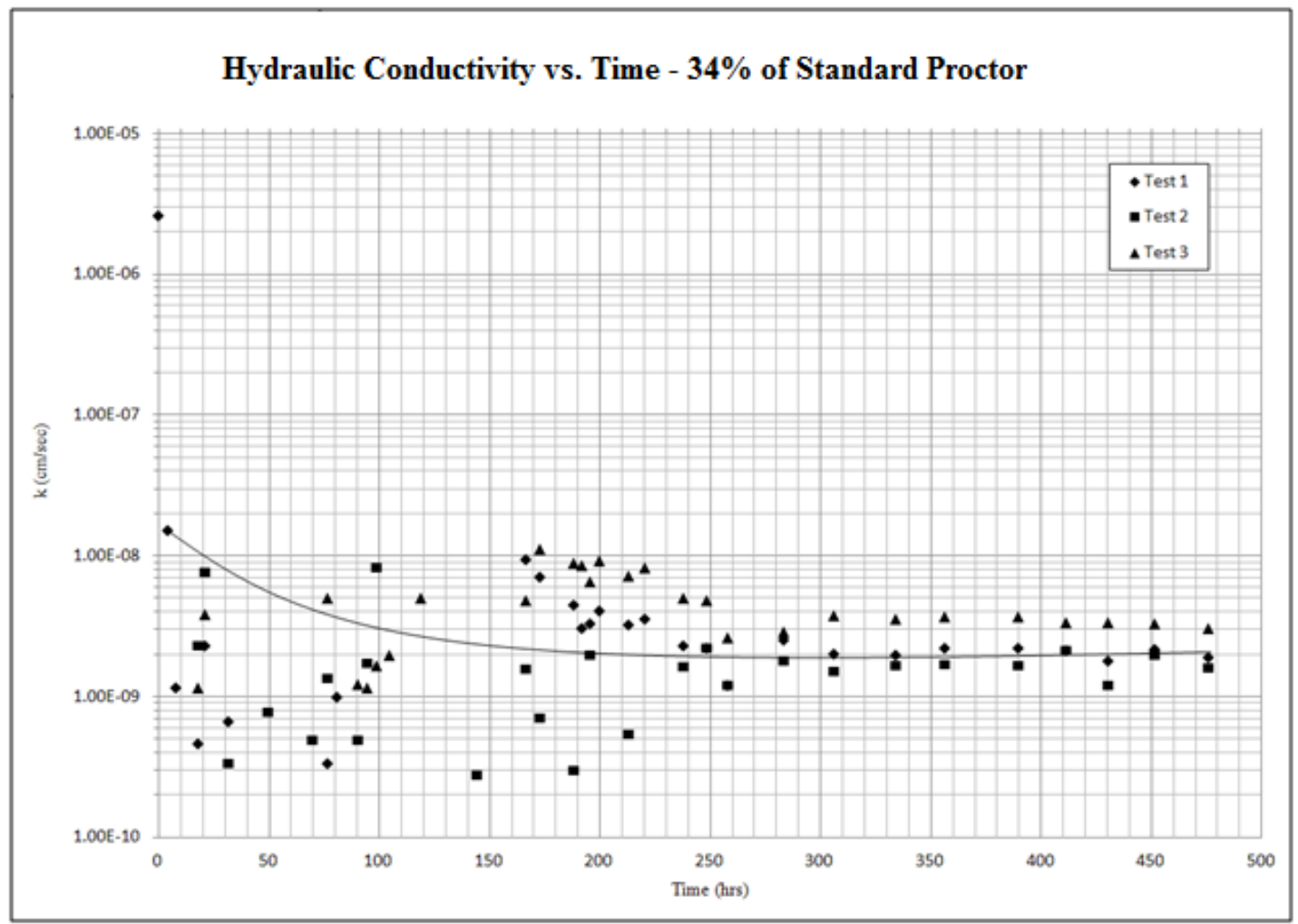

Figure 4.10: Hydraulic conductivity - 34\% of Standard Proctor

Hydraulic conductivity testing was performed on specimen at $11 \%$ of Standard Proctor compaction effort $\left(67.85 \mathrm{~kJ} / \mathrm{m}^{3}\right)$. The target dry density was at the minimum for the low compaction effort test data. The minimum dry density for the low compaction effort specimen was $14.9 \mathrm{kN} / \mathrm{m}^{3}$. Triplicate testing was performed to ensure accuracy. The dry densities for tests 1,2 , and 3 were $15.14 \mathrm{kN} / \mathrm{m}^{3}, 15.52 \mathrm{kN} / \mathrm{m}^{3}$, and $15.49 \mathrm{kN} / \mathrm{m}^{3}$ respectively. The average hydraulic conductivity $(\mathrm{m} / \mathrm{s})$ for each test was found to be was found to be $1.89 \times 10^{-9}, 2.43 \times 10^{-}$ ${ }^{9}$, and $3.60 \times 10^{-9}$. The results are summarized Tables 4.20 and 4.21 and plotted in Figure 4.11 below.

Table 4.20: Hydraulic conductivity results - 11\% of Standard Proctor

\begin{tabular}{|c|c|c|c|}
\hline Test & 1 & 2 & 3 \\
\hline Average Hydraulic Conductivity $(\mathrm{m} / \mathrm{s})$ & $1.89 \mathrm{E}-09$ & $2.43 \mathrm{E}-09$ & $3.60 \mathrm{E}-09$ \\
\hline Sample Standard Deviation $(\mathrm{s})$ & $2.37 \mathrm{E}-10$ & $3.22 \mathrm{E}-10$ & $4.35 \mathrm{E}-10$ \\
\hline Coefficient of Variation $(\mathrm{COV})$ & 0.125 & 0.133 & 0.121 \\
\hline
\end{tabular}


Table 4.21: Hydraulic conductivity results $-11 \%$ of Standard Proctor

\begin{tabular}{|c|c|}
\hline Average Hydraulic Conductivity from 3 Tests $(\mathbf{m} / \mathbf{s}):$ & $\mathbf{2 . 6 4 E - 0 9}$ \\
\hline Sample Standard Deviation (s) & $8.74 \mathrm{E}-10$ \\
\hline Coefficient of Variation (COV) & 0.544 \\
\hline
\end{tabular}

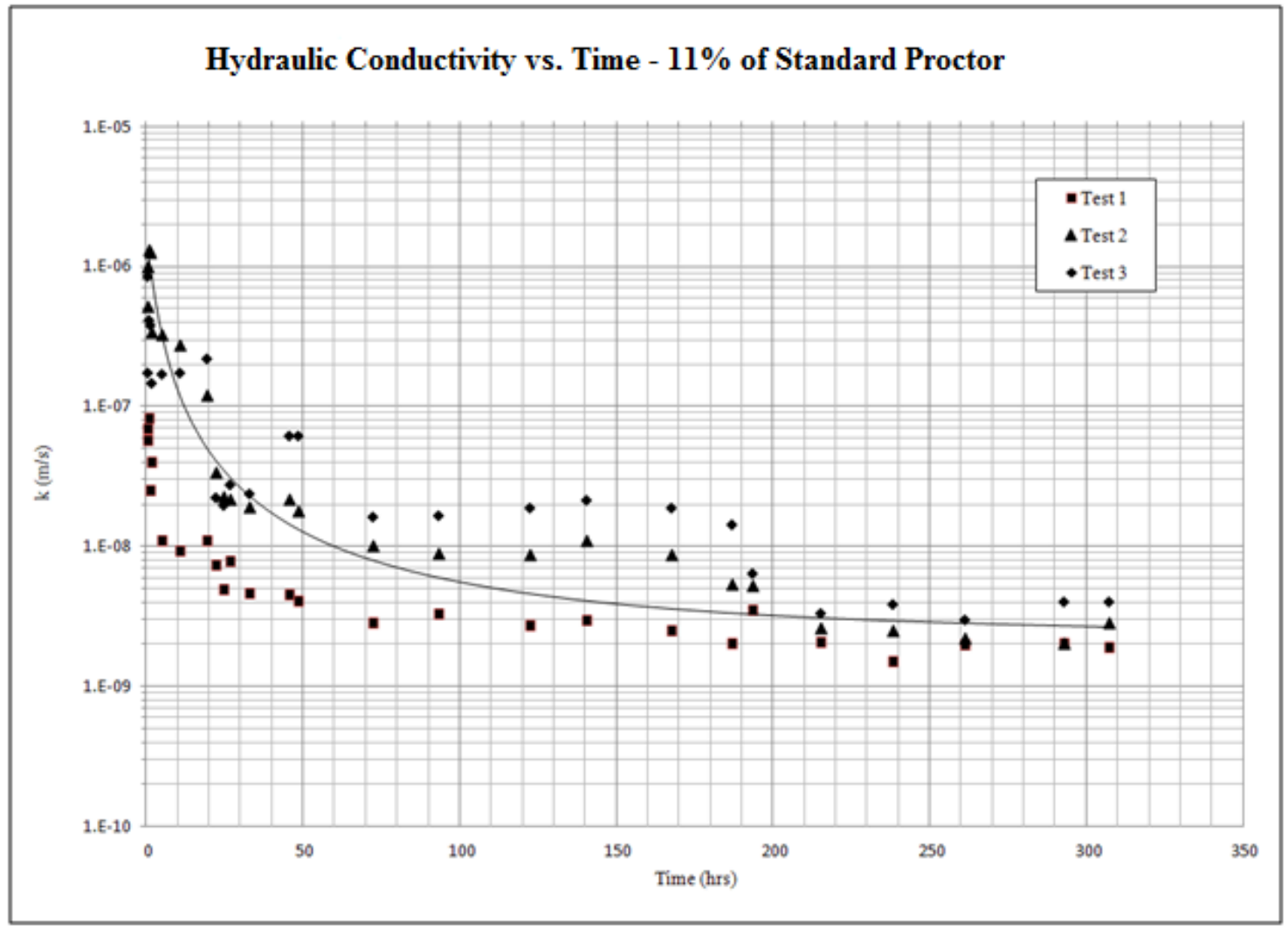

Figure 4.11: Hydraulic conductivity - 11\% of Standard Proctor 


\section{NUMERICAL MODELING}

The numerical model used to analyze the fills was the finite element model of GeoStudio 2007. Modeling in GeoStudio required three general steps. First, the geometry of the model had to be identified and discretized into elements. After that had been done, material properties had to be defined and then boundary conditions applied. Modeling was done for both an AOC fill and a geomorphic fill, which are described in detail in the section. The SEEP/W module was used to analyze the fill with regards to seepage. The SIGMA/W module was used to determine the deformation of the fill in response to groundwater seepage, and the resultant slope stability was analyzed using the SLOPE/W module. The slope stability analysis was performed to show if seepage would affect the stability of the fill:

\subsection{Geometry}

For any modeling to be completed, the geometry of both the AOC and geomorphic fills first had to be defined. The geometry of each fill was taken from plan view contours. A profile slice was taken alone the centerline of the slope, as to produce the longest profile slice within the fill and to include the drain within the fill. In SEEP/W, the profile used a default thickness of 1 meter to calculate volumes. The geometry consisted of three regions.

1. A foundation rock region (original ground)

2. A fill material region above the foundation rock

3. A blocky core drain between the foundation rock and fill material

An approximate global mesh size of $10 \mathrm{~m}$ was used. Figures 5.1 and 5.2 below are the profiles from SEEP/W for each fill with axes to show size. Units for distance and elevation are in meters. The three distinct regions can be seen. Following the figures are explanations of how each fill geometry was defined. 


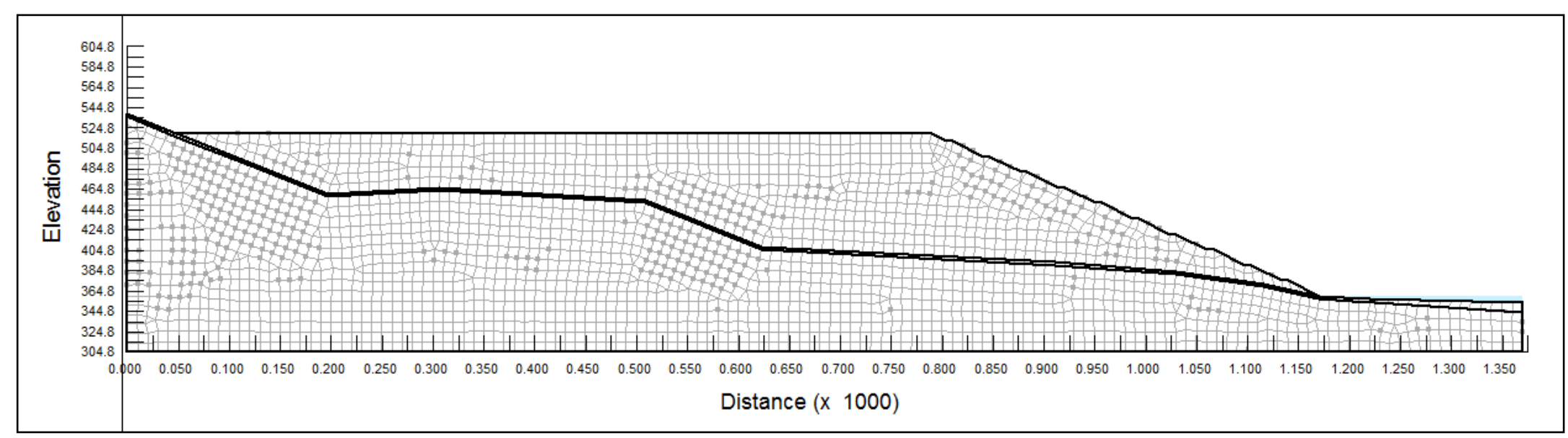

Figure 5.1: AOC fill geometry (distance and elevation in meters)

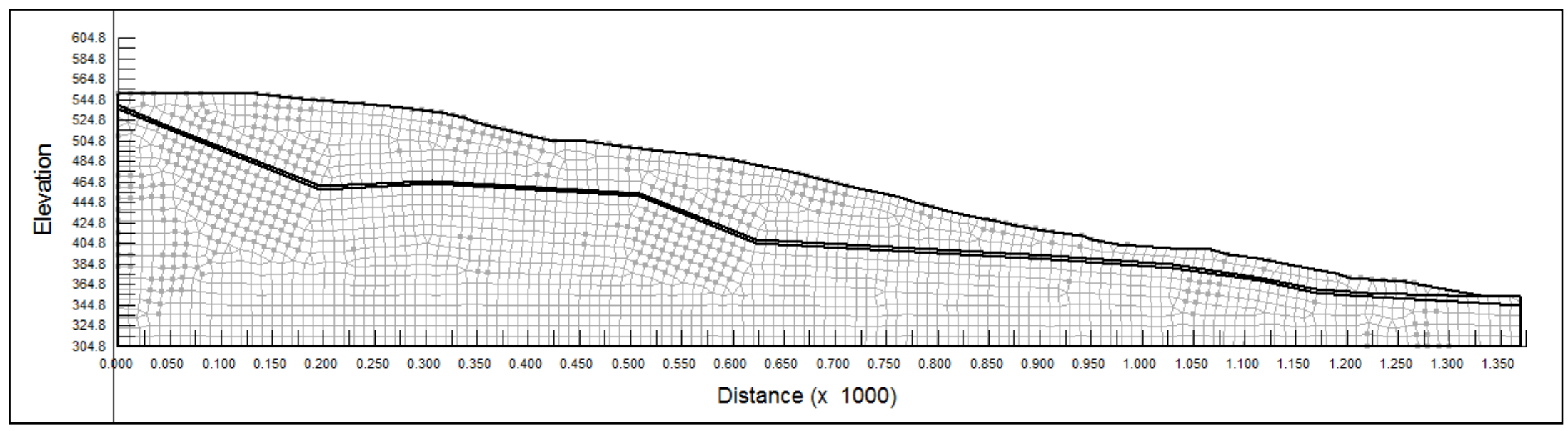

Figure 5.2: Geomorphic fill geometry (distance and elevation in meters) 


\subsubsection{AOC Fill}

The geometry for the profile view of the valley fill was taken from the fill cross-section details in the WVDEP (2007) permit file slope stability analysis. Coordinates were given in U.S. customary units (ft). These were converted to metric because distance in the model was measured in meters. Figure 5.3 below shows the coordinates (in meters) from the permit file used for the AOC fill.

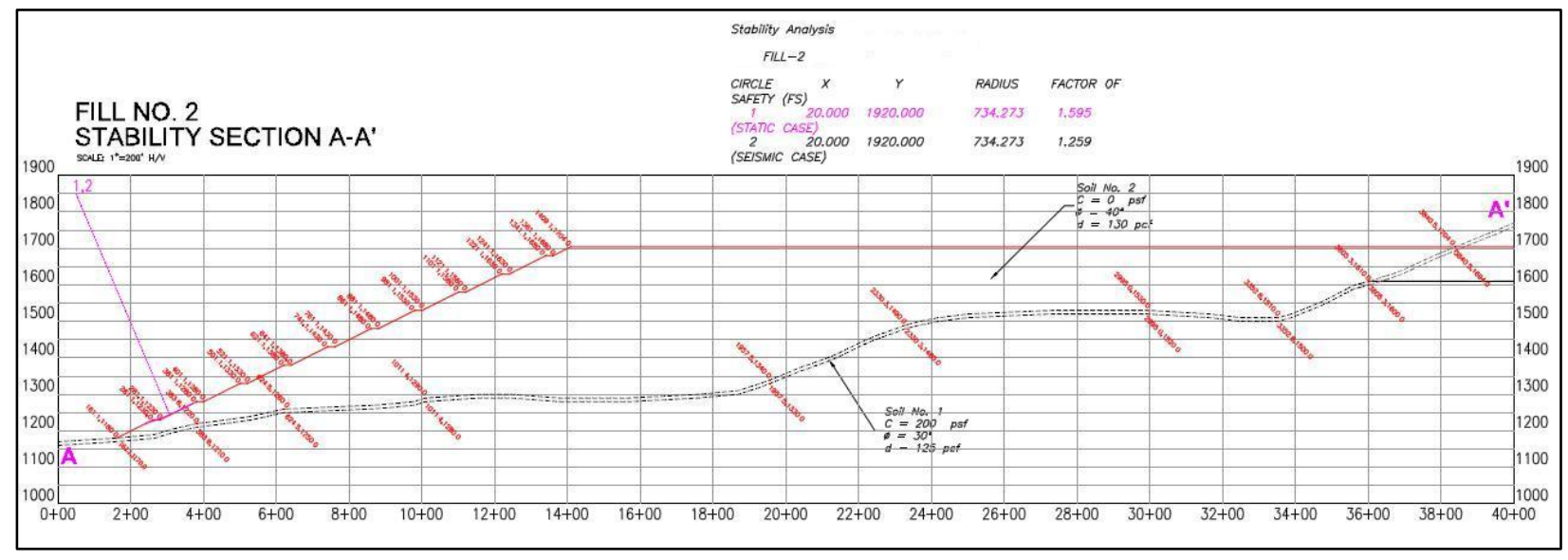

Figure 5.3: AOC fill coordinates (in meters)

The fill was modeled from an elevation of $304.8 \mathrm{~m}$ to $519.4 \mathrm{~m}$ with a length of $1370 \mathrm{~m}$. The face of the fill was modeled at an elevation of $359.7 \mathrm{~m}$ to $519.4 \mathrm{~m}$ and from a horizontal location of $789.7 \mathrm{~m}$ to $1170.1 \mathrm{~m}$. The curved line throughout the middle of the fill was a 10 foot thick core drain. The discharge pond of the fill was set at an elevation of $359.7 \mathrm{~m}$. A plan view of the fill is shown in Figure 5.4 below with a black line showing where the profile slice was taken. 


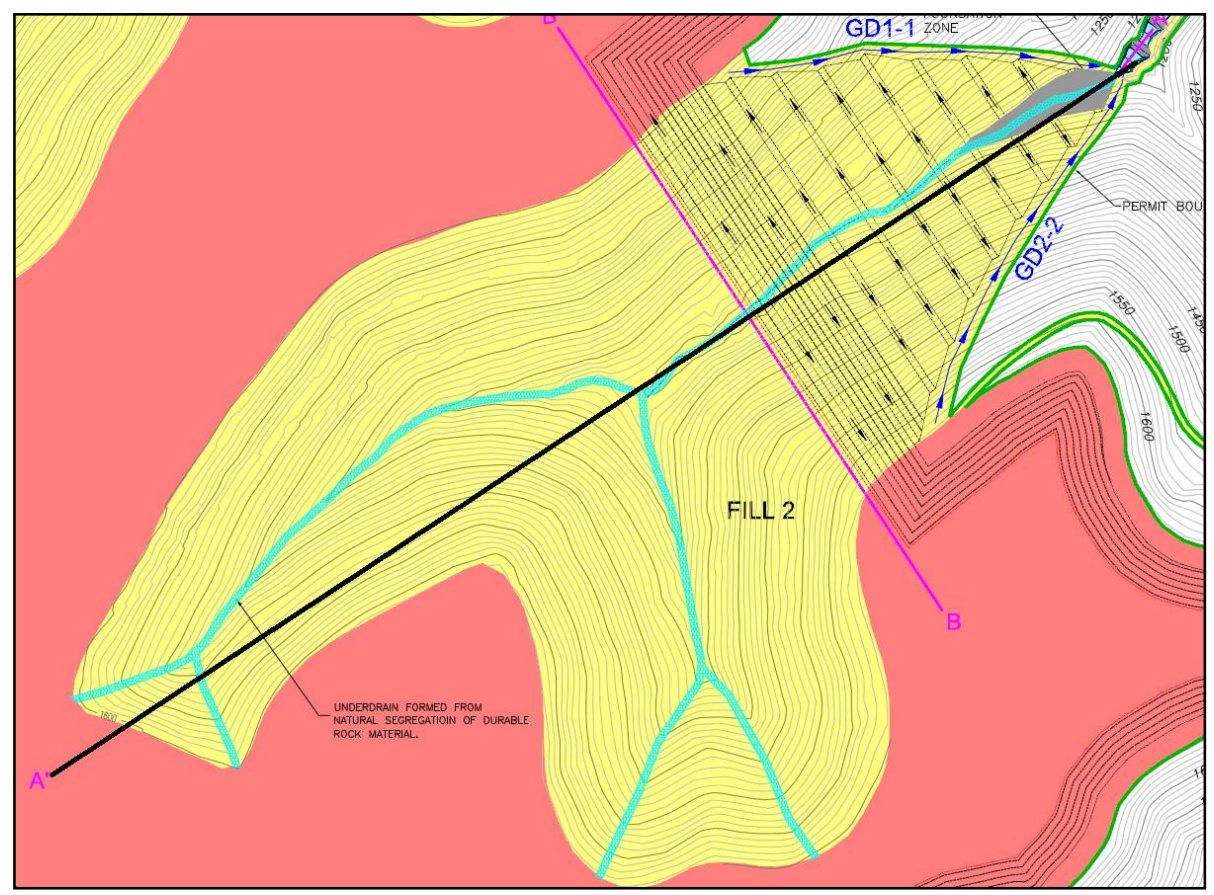

Figure 5.4: AOC fill plan view with profile slice

The coordinates were first mirrored (GeoStudio models slope stability, groundwater seepage, and deformation in a left-to-right condition) and then input into Geostudio to define the geometry of the model.

\subsubsection{Geomorphic Fill}

The same geometry for the foundation rock and blocky core drain were used for the geomorphic fill. Only the surface geometry of the fill material was altered. The profile slope was taken from a geomorphic design using the Carlson Natural Regrade software. Plan views are shown below. Figure 5.5 shows the contours of the geomorphic fill with a black line corresponding to the location of the profile slice. Figure 5.6 shows a hillshade of the fill to give a sense of the slopes of the surface. Darker colors correspond to a steeper slope. 


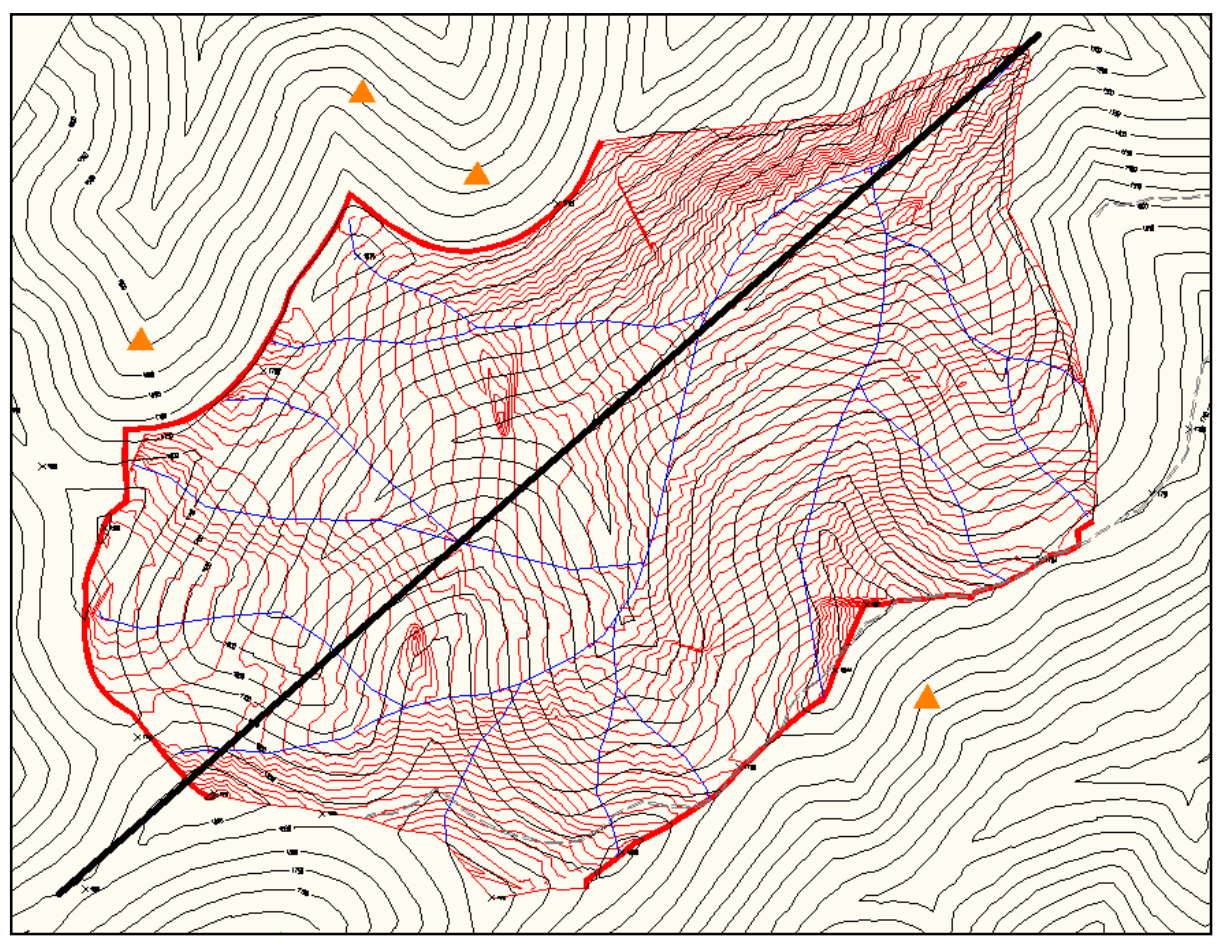

Figure 5.5: Geomorphic fill plan view with profile slice

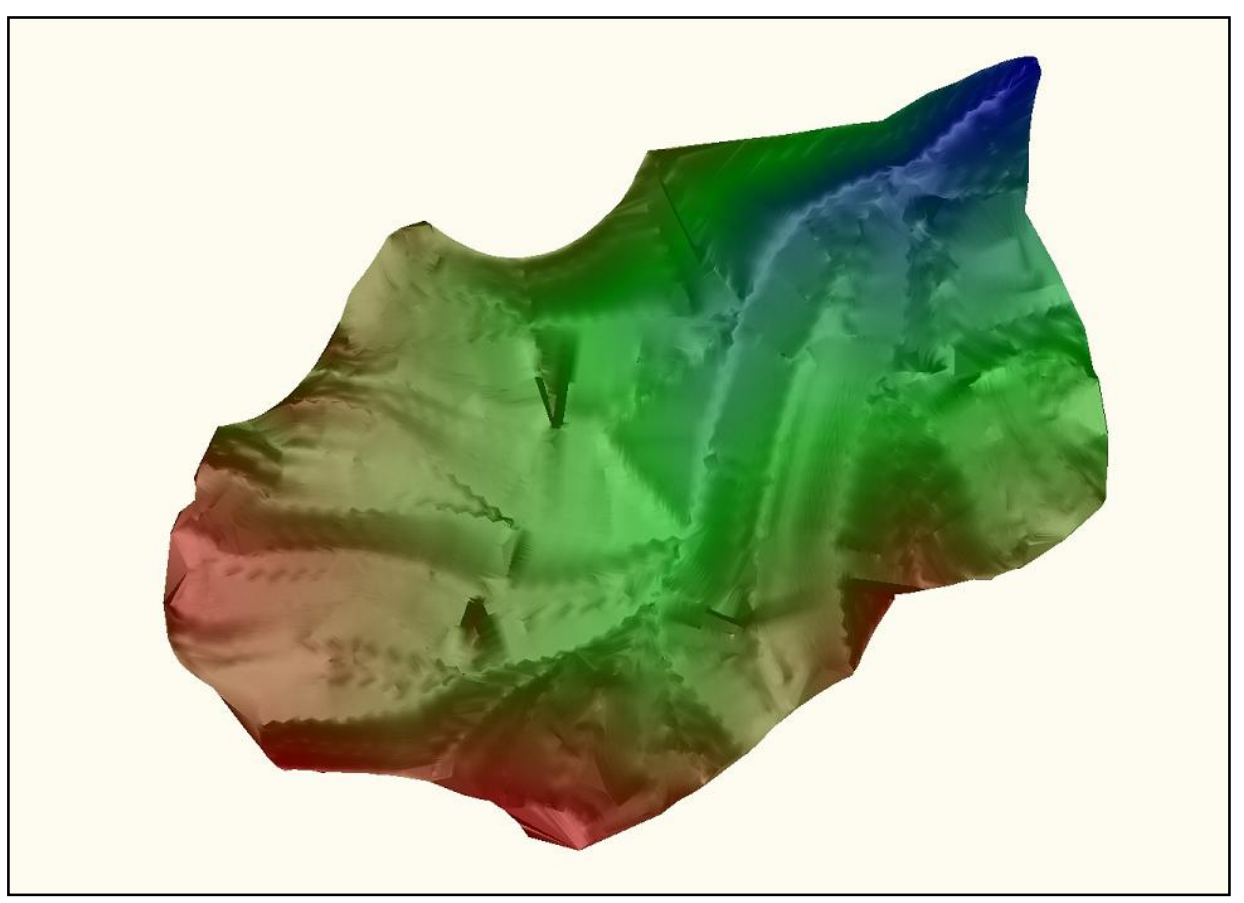

Figure 5.6: Geomorphic fill hillshade 
The coordinates of the surface were taken along the profile slice and then input as the surface coordinates in GeoStudio.

\subsection{Groundwater Seepage Modeling}

SEEP/W was the module used to model groundwater seepage in a two-dimensional state. SEEP/W uses material properties and boundary conditions to generate contours and $\mathrm{x}-\mathrm{y}$ plots of parameters such as head, pressure, gradient, velocity, and hydraulic conductivity. A transient condition can be applied to model a changing water table over time. Seepage for the valley fill was analyzed in a transient condition over the span of 10 years using finite element modeling. 10 time steps were modeled to produce model results for each of the 10 years. A maximum of 50 iterations was chosen with a maximum of 5 reviews per time step. Initial pore-water pressure conditions were set to be taken from a manually input initial water table. With the geometry of each fill already defined, the next step was defining the material properties. Finally, by developing the site hydrology, boundary conditions were applied.

\subsubsection{Materials}

The valley fill model consisted of three materials:

1. Fill

2. Foundation Rock

3. Blocky Core Drain

For both fills, each material was given the same properties because the same materials were used in both designs. These materials for each fill can be seen Figures 5.7 and 5.8 below. 


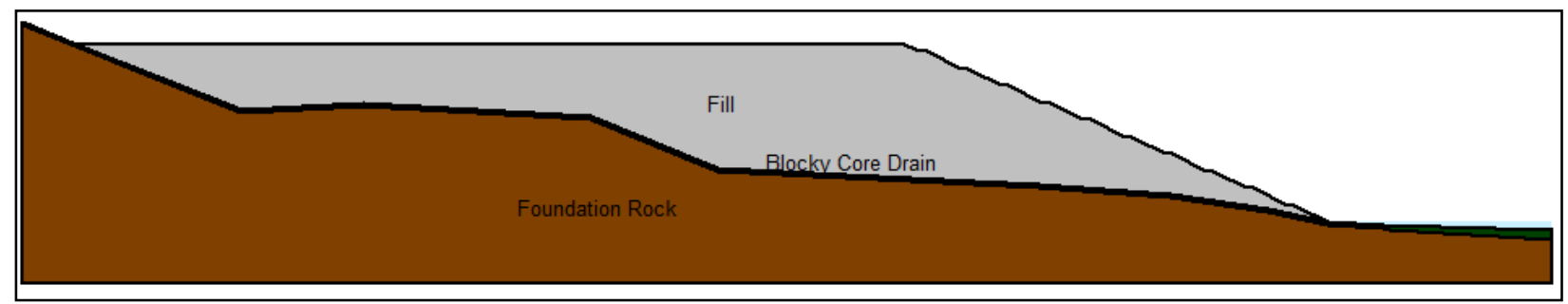

Figure 5.7: AOC fill materials

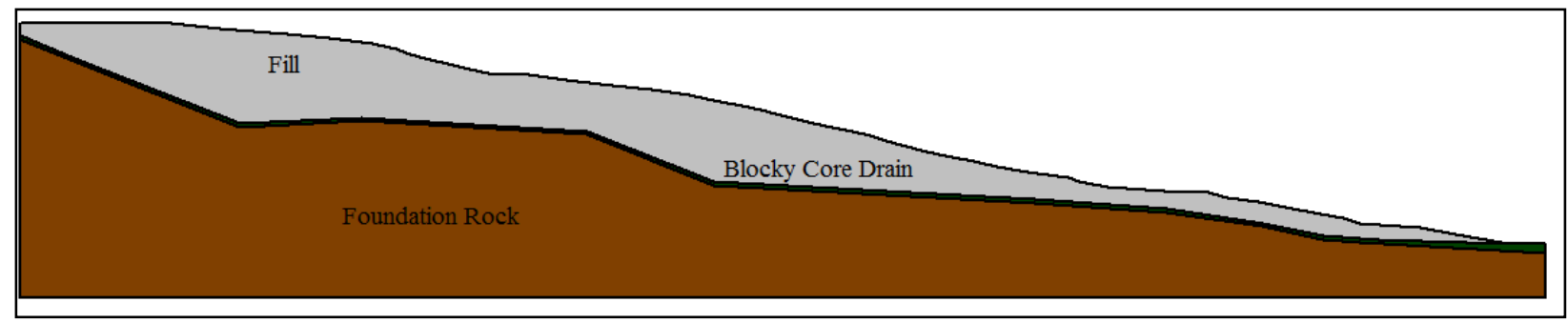

Figure 5.8: Geomorphic fill materials

The first material, named "Fill", was the top layer of the valley fill comprised of coal overburden from mining. It was modeled under a saturated/unsaturated condition. This allowed the material to begin in an unsaturated state and become saturated over time. Modeling in the saturated/unsaturated condition required a function for hydraulic conductivity and water content. Hydraulic conductivity $(\mathrm{m} / \mathrm{s})$ was plotted versus pore water pressure $(\mathrm{kPa})$ by inputting a saturated hydraulic conductivity and using the van-Genuchten estimation method within SEEP/W. A minimum suction was set at $0.01 \mathrm{kPa}$ and a maximum set at $1000 \mathrm{kPa}$ with 20 data points to produce a function. Hydraulic conductivity was chosen from a range values found from previous work done with waste rock tailings. These ranged from an unsaturated hydraulic conductivity of $1 \times 10^{-5} \mathrm{~m} / \mathrm{s}$ stated by Abdelghani et al. (2009) to a saturated hydraulic conductivity of $1 \times 10^{-7} \mathrm{~m} / \mathrm{s}$ stated by Aubertin et al. (1996). The function is shown in Figure 5.9 below. 


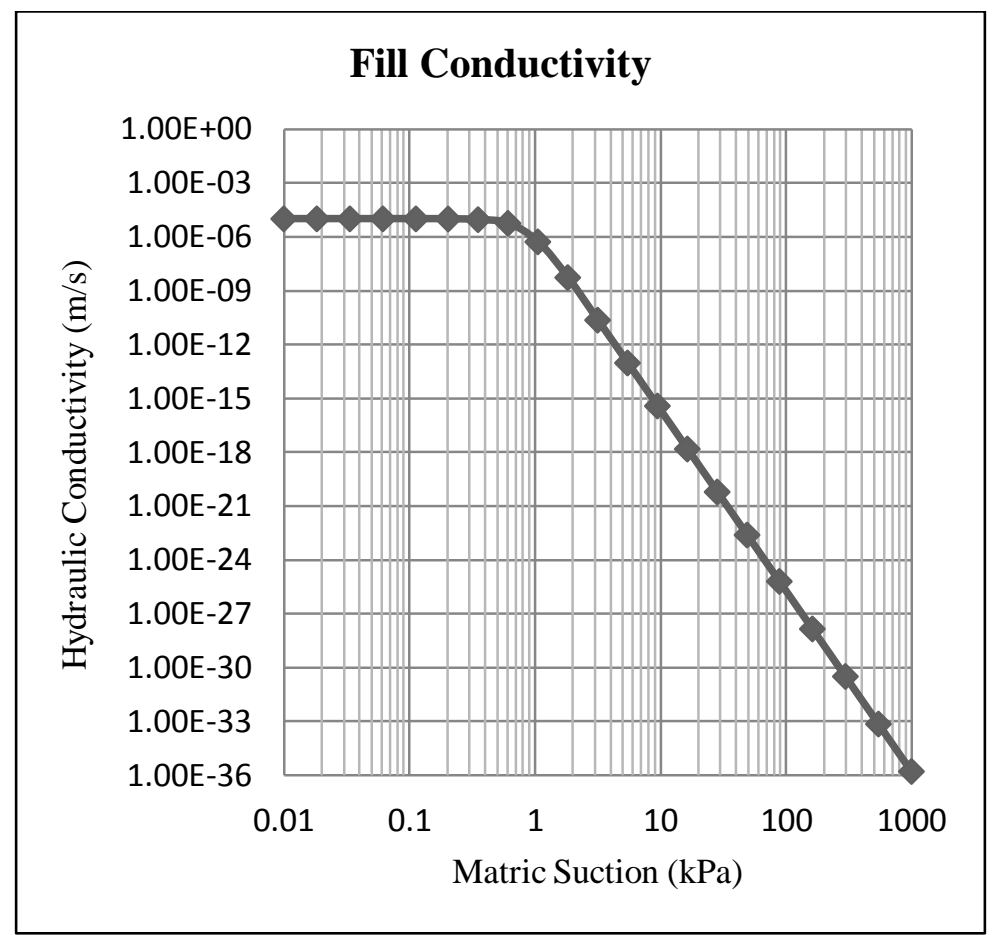

Figure 5.9: Fill conductivity function - AOC fill

This function was also compared to the function produced by Fredlund et al (1998) and found to be quite similar. The water content function (soil-water characteristic curve) was produced in a similar way. Saturated volumetric water content was input and the same parameters as the conductivity function were used to create a function. Sand was chosen as the material type for this function to correspond with soil classification of "well graded sand" that was determined in laboratory testing. Saturated volumetric water content was taken to be $44 \%$, the value used by Fredlund et al (1998). This function is shown in Figure 5.10 below. 


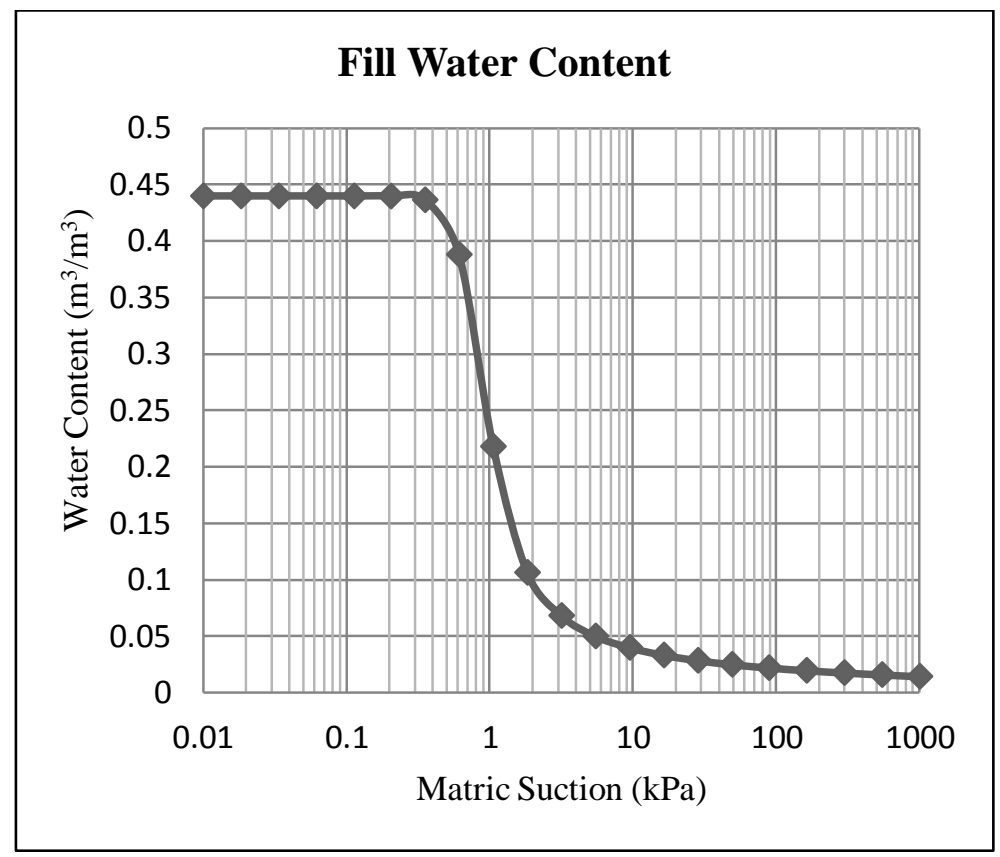

Figure 5.10: Fill water content function - AOC fill

The bottom layer of the valley fill, the "Foundation Rock" layer, was modeled in a saturated only condition with a very low hydraulic conductivity $\left(2 \times 10^{-12} \mathrm{~m} / \mathrm{s}\right)$ to simulate an impermeable rock layer. Between the "Fill" layer and "Foundation Rock" layer, a 10-ft "Blocky Core Drain" material was placed. This layer was modeled under a saturated only condition with a constant hydraulic conductivity value of $0.1 \mathrm{~m} / \mathrm{s}$. This hydraulic conductivity was taken from the Das (2010) average value for gravel. Table 5.1 below summarizes the inputs used to define the material properties of each fill.

Table 5.1: SEEP/W material inputs

\begin{tabular}{|c|c|c|c|}
\hline Material & Fill & $\begin{array}{c}\text { Foundation } \\
\text { Rock }\end{array}$ & $\begin{array}{c}\text { Blocky Core } \\
\text { Drain }\end{array}$ \\
\hline Condition & saturated/unsaturated & saturated only & saturated only \\
\hline $\begin{array}{c}\text { Hydraulic Conductivity } \\
\text { Modeling }\end{array}$ & function & constant & constant \\
\hline $\begin{array}{c}\text { Unsaturated Hydraulic } \\
\text { Conductivity (m/s) }\end{array}$ & $1.00 \mathrm{E}-05$ & NA & NA \\
\hline $\begin{array}{c}\text { Saturated Hydraulic } \\
\text { Conductivity }\end{array}$ & $1.00 \mathrm{E}-07$ & $2.00 \mathrm{E}-12$ & 0.1 \\
\hline
\end{tabular}




\subsubsection{Boundary Conditions}

Once materials and site hydrology were defined, boundary conditions were determined to fully define the model. To do this, an infiltration function was developed from the NOAA precipitation data. It is important to note that the SEEP/W analysis did not take into account any stream infiltration, only infiltration from precipitation. For modeling a valley fill, two different infiltration functions had to be developed:

1. A function for water infiltrating on a flat surface (the top of the fill)

2. A function for water infiltrating on a sloped surface (the face of the fill)

A study by Sharma et al. (1983) stated that infiltration into a flat sand surface ranges from 75$95 \%$ of the accumulated rainfall. For the top of the slope, each daily rainfall value was multiplied by an average value of $85 \%$ to obtain the infiltration depth. Studies by Ziemkiewicz (2011) and Meek and O'dell (2012) stated that the percentage of precipitation on the face of a fill that infiltrates the surface was $52 \%$ and $58 \%$, respectively. Using these values, the daily precipitation totals were multiplied by 0.55 (average of the two values) to determine the amount of rainfall that infiltrated into the sloped portion of the fill. To determine how long precipitation from a given storm infiltrated, the precipitation depth was compared to the unsaturated hydraulic conductivity. With an unsaturated hydraulic conductivity of $36 \mathrm{~mm} / \mathrm{hr}$ (determined by performing unit conversion on $1 \times 10^{-5} \mathrm{~m} / \mathrm{s}$ ), any precipitation depth of less than $36 \mathrm{~mm}$ would take less than 1 hour to infiltrate fully. To maintain a minimum time step of 1 hour within the model, any precipitation depth of $36 \mathrm{~mm}$ or less was given a duration of 1 hour. Any precipitation depth of greater than $36 \mathrm{~mm}$ was divided by $36 \mathrm{~mm} / \mathrm{hr}$ to determine the duration. Once all durations were calculated, each infiltration depth was divided by its duration to determine the infiltration rate in $\mathrm{m} / \mathrm{s}$. As seen in the Horton infiltration functions for all design storms, any storm that had an initial infiltration rate of greater than the saturated hydraulic conductivity $\left(1 \times 10^{-7} \mathrm{~m} / \mathrm{s}\right)$ had an infiltration function that decreased to the magnitude of the saturated hydraulic conductivity after one hour. Each duration, for this reason, was given the initial calculated infiltration rate followed by an infiltration rate of $1 \times 10^{-7} \mathrm{~m} / \mathrm{s}$ after one hour. This infiltration rate then continued for the remainder of the infiltration duration. 
A spreadsheet was then developed for one year's worth of precipitation data depicting infiltration rate over time for both the $85 \%$ infiltration and 55\% infiltration. On day one of the $55 \%$ infiltration function, for example, water infiltrated at $1.22 \times 10^{-7} \mathrm{~m} / \mathrm{s}$ then decreased to $1 \times 10^{-7} \mathrm{~m} / \mathrm{s}$ after one hour, followed by an infiltration of $0 \mathrm{~m} / \mathrm{s}$ for the remaining 23 hours of the day. At the beginning of day two, infiltration began again at $7.64 \times 10^{-8} \mathrm{~m} / \mathrm{s}$. The two infiltration functions for one year can be seen in Figures 5.11 and 5.12 below:

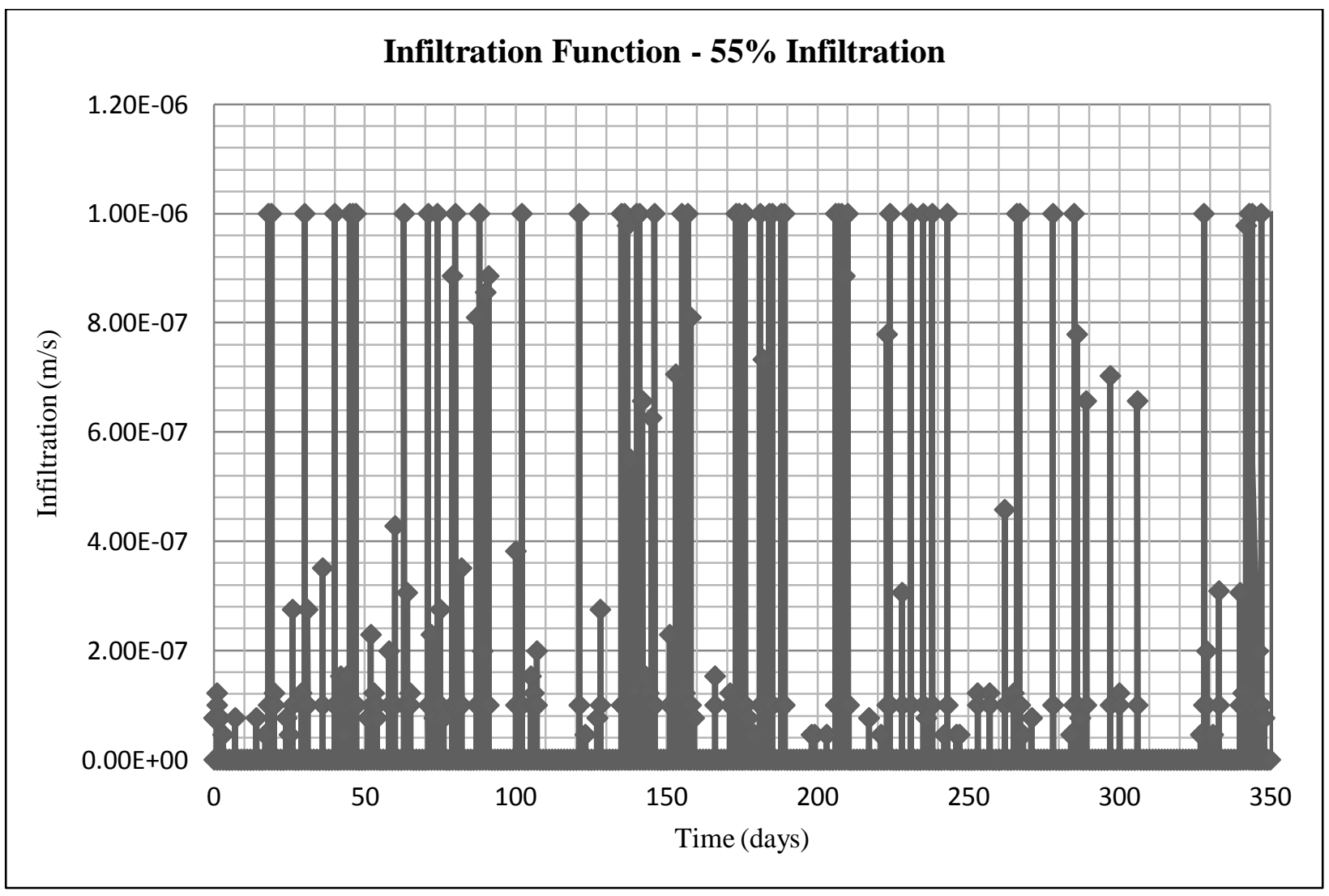

Figure 5.11: 55\% infiltration function for valley fill 


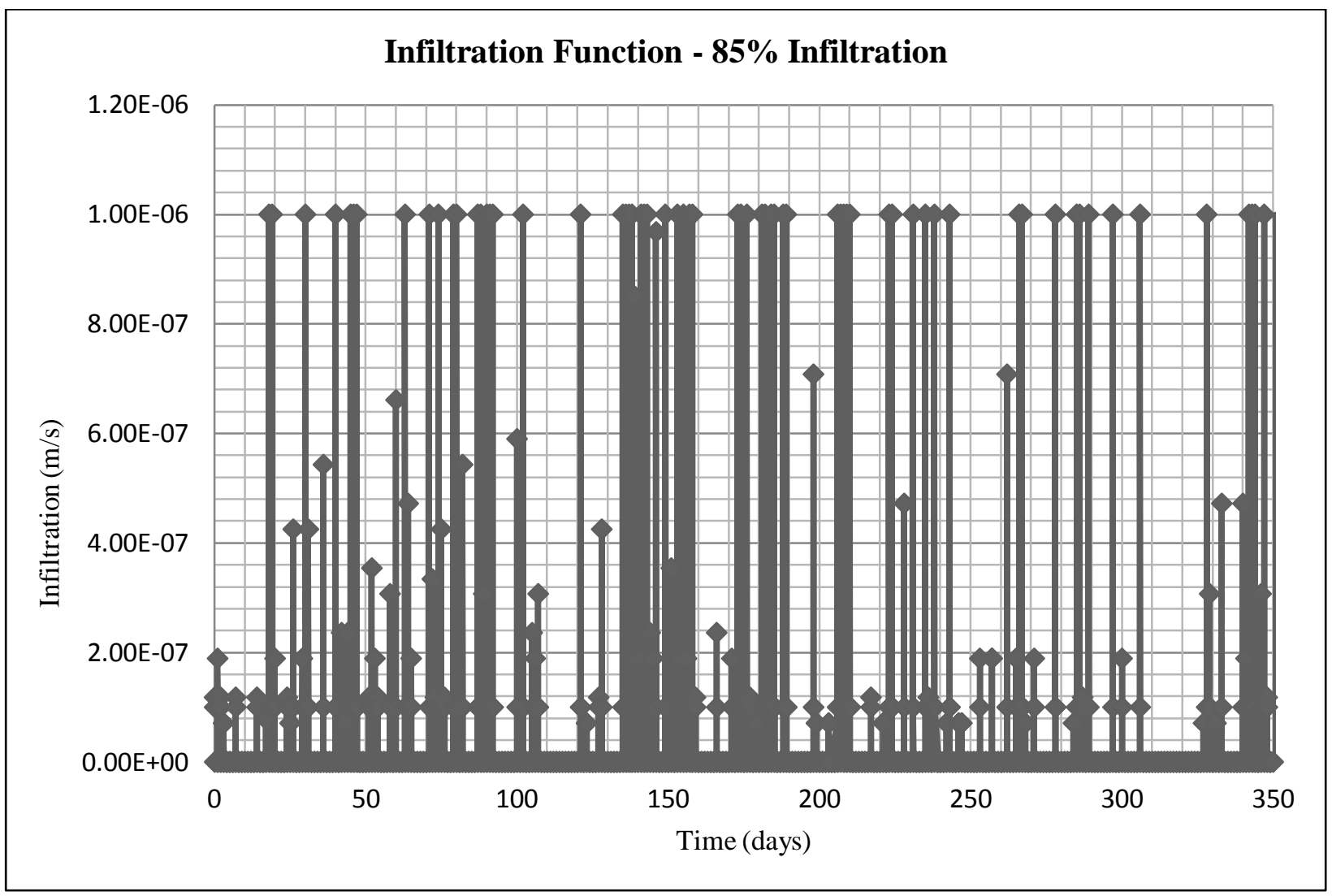

Figure 5.12: $85 \%$ infiltration function for valley fill

These one year functions were repeated ten times in order to be used in a model that spanned ten years. These ten year infiltration functions were then keyed into SEEP/W as a step data point function for infiltration (unit flux vs. time) to produce the infiltration boundary conditions.

The boundary conditions and their applied locations for each fill are shown in Figures 5.13 and 5.14 below. The locations of their applications are described following the figures. 


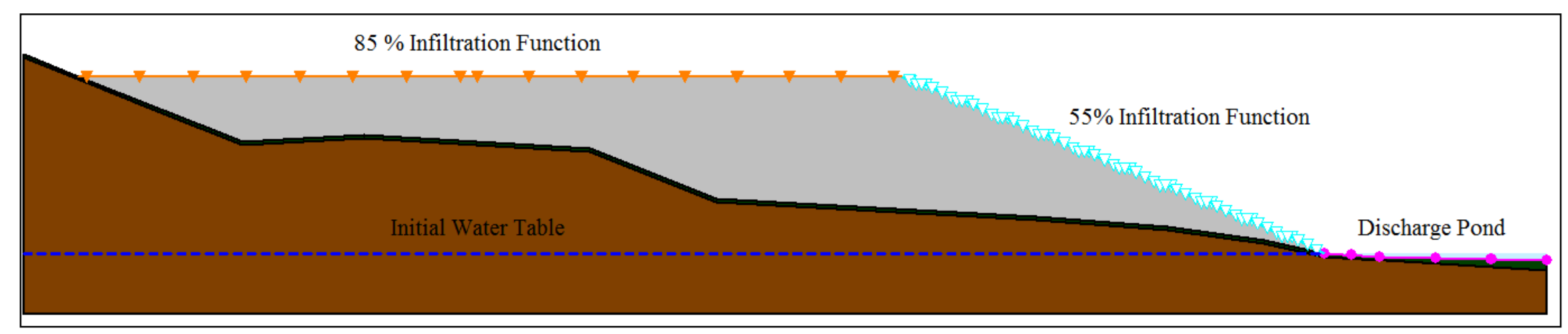

Figure 5.13: AOC fill boundary conditions

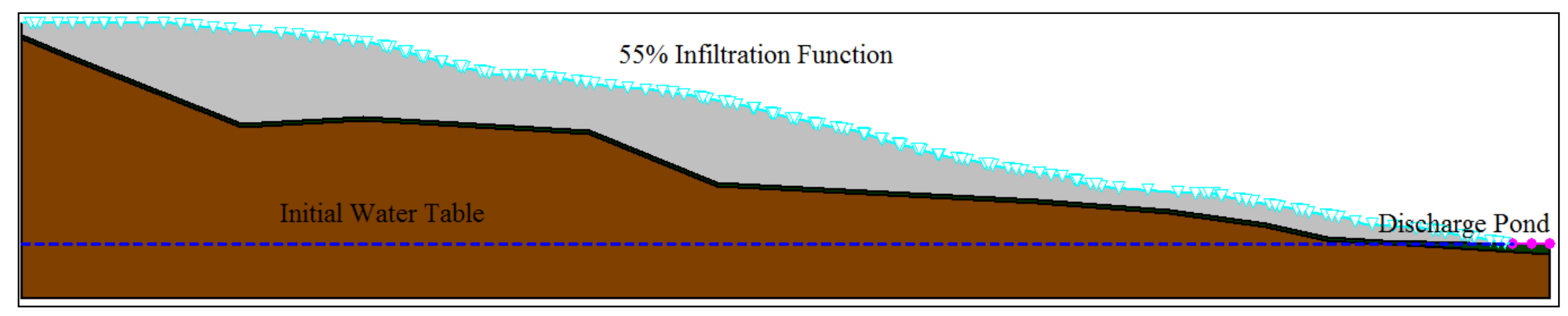

Figure 5.14: Geomorphic fill boundary conditions 
For the AOC fill, the $85 \%$ infiltration function boundary condition was applied to the top of the fill, and the 55\% infiltration designation was applied to the downstream sloped face of the fill. The $55 \%$ infiltration function boundary condition placed on the fill downstream face was also analyzed as a potential seepage face. A constant head function was applied at the toe of the fill to model the discharge pond. The head value was input as the elevation of the discharge pond. Groundwater seepage modeling with SEEP/W also required inputting an initial water table. The water table was placed at a constant level through the foundation rock at the elevation of the discharge pond. A closer view of the boundary conditions at the toe of the fill is shown in Figure 5.15 below.

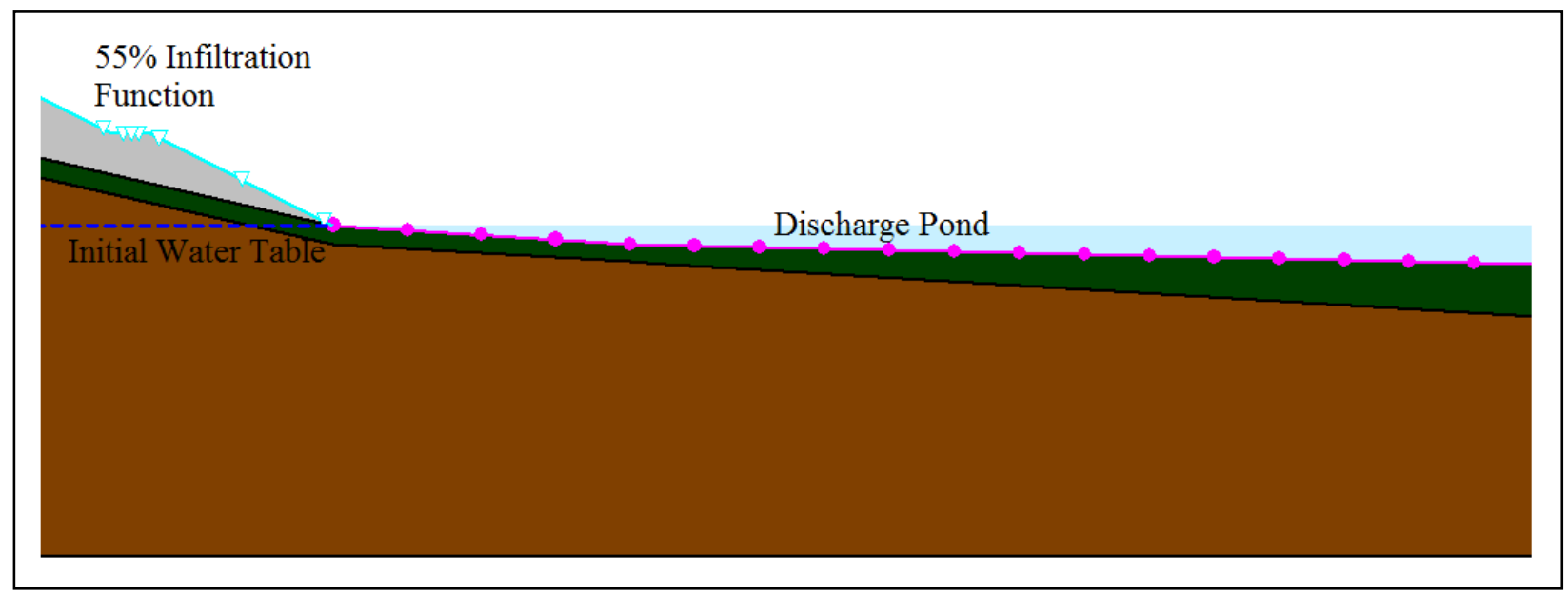

Figure 5.15: AOC boundary conditions at toe

The same boundary conditions were used to define the geomorphic model as were used in the AOC model. For this case, however, the entire fill surface used the 55\% infiltration boundary condition because it is sloped for its entire length. The sloped fill surface was also analyzed as a potential seepage face. Due to the altered surface profile, the initial water table and discharge pond were modeled at a height of $353.57 \mathrm{~m}$, slightly lower than in the AOC fill. A closer view of the boundary conditions at the toe of the fill is shown in Figure 5.16 below. 


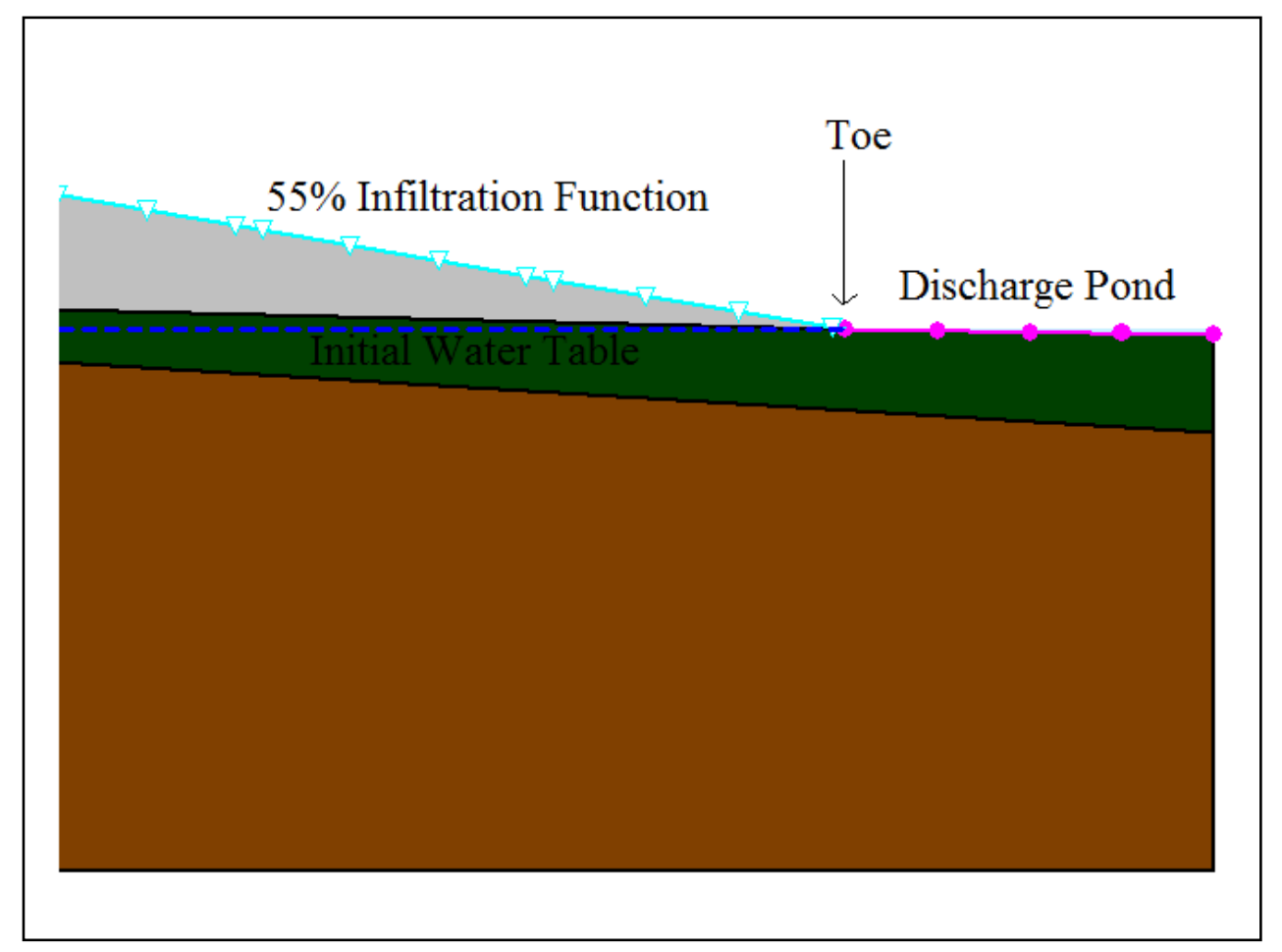

Figure 5.16: Geomorphic fill boundary conditions at toe

\subsection{Deformation and Slope Stability Modeling}

The results from SEEP/W illustrated areas of storage, areas of increased hydraulic head, and elevated pore pressures. The results from this analysis were utilized as parent inputs to a SIGMA/W deformation analysis. The SIGMA/W analysis, via finite element modeling techniques, calculated insitu stresses within the fill structure as a result of seepage. These stresses were used to calculate a factor of safety using the SLOPE/W module of GeoStudio.

SLOPE/W used both a sensitivity analysis and a deterministic analysis to calculate factor of safety using general limit equilibrium. Sensitivity analysis was used to determine to which parameter the design stability is most sensitive. If the geometry and conditions happen to be more sensitive to a certain parameter, it meant that small changes or little variability in the parameter could result in more dramatic result changes as compared to other parameters. It is valuable to know which parameter is the most critical. This knowledge is important to determine the amount of risk involved in a specific earthwork design. Deterministic analysis was 
performed on all slopes considered in order to give a range of factors of safety to more accurately assess the stability of each slope. For both the sensitivity and deterministic analyses, factor of safety was determined for a crest, toe, face, and deep failure.

\subsubsection{Materials}

The three material designations were the same as in seepage modeling. The parameters taken into consideration for SIGMA/W modeling were elastic modulus, unit weight, and Poisson's ratio. These inputs for the deterministic and sensitivity analyses were taken from the previous soil testing and are summarized in Table 5.2 below.

\section{Table 5.2: SIGMA/W material inputs}

\begin{tabular}{|c|c|c|c|}
\hline Material & $\begin{array}{c}\text { Elastic Modulus } \\
(\mathrm{kPa})\end{array}$ & $\begin{array}{c}\text { Unit Weight } \\
\left(\mathrm{kN} / \mathrm{m}^{3}\right)\end{array}$ & $\begin{array}{c}\text { Poisson's } \\
\text { Ratio }\end{array}$ \\
\hline Fill & 29868 & 18.39 & 0.388 \\
\hline Foundation Rock & 1000000 & 26.48 & 0.38 \\
\hline Blocky Core Drain & 29268 & 18.39 & 0.338 \\
\hline
\end{tabular}

The parameters taken into consideration for SLOPE/W assessment were the friction angle $(\varphi)$ and the unit weight $\left(\gamma_{\mathrm{d}}\right)$. The cohesion was considered to be zero $\mathrm{kPa}$. These inputs for the deterministic and sensitivity analyses were taken from the previous soil testing and are summarized in Tables 5.3 and 5.4 below.

Table 5.3: SLOPE/W deterministic analysis material inputs

\begin{tabular}{|c|c|c|c|}
\hline Material & $\begin{array}{c}\text { Unit } \\
\text { Weight } \\
\left(\mathrm{kN} / \mathrm{m}^{3}\right)\end{array}$ & $\begin{array}{c}\text { Cohesion } \\
(\mathrm{kPa})\end{array}$ & $\begin{array}{c}\text { Friction } \\
\text { Angle }\left({ }^{\circ}\right)\end{array}$ \\
\hline Fill & 18.39 & 0 & 27.7 \\
\hline Foundation Rock & 18.39 & 0 & 27.7 \\
\hline Block Core Drain & 19.64 & 9.58 & 30 \\
\hline
\end{tabular}


Table 5.4: SLOPE/W sensitivity analysis material inputs

\begin{tabular}{|c|c|c|c|c|c|}
\hline & \multicolumn{2}{|c|}{ Unit Weight $\left(\mathrm{kN} / \mathrm{m}^{3}\right)$} & \multicolumn{2}{c|}{ Cohesion (kPa) } & \multicolumn{2}{c|}{ Friction Angle (०) } \\
\hline Material & $\begin{array}{c}\text { Slip Surface } \\
\text { Calculation Value }\end{array}$ & Mean & $\begin{array}{c}\text { Slip Surface } \\
\text { Calculation Value }\end{array}$ & Mean & $\begin{array}{c}\text { Slip Surface } \\
\text { Calculation Value }\end{array}$ \\
\hline Fill Mean \\
\hline $\begin{array}{c}\text { Foundation } \\
\text { Rock }\end{array}$
\end{tabular}

A slope stability analysis was also performed on both fills under a fully saturated case. This represented the worst possible case with respect to groundwater and slope stability. The SLOPE/W module was used to perform this slope stability analysis. The water table was input at the surface of each fill to simulate a fully saturated case, and the same material inputs were used as in the other SLOPE/W analyses.

\subsubsection{Boundary Conditions}

Entry and exit locations were chosen to produce differing failure planes. These differing failure planes produced factors of safety for four possible failure modes. The AOC fill analyzed a crest, toe, face, and deep failure. The geomorphic fill analyzed a crest, toe and face failure. Porewater pressure conditions were taken from the SEEP/W analysis for each fill. 


\section{RESULTS AND ANALYSIS}

The following section first discusses the results of soil testing. Next the results of seepage modeling for each fill are presented and compared. Finally, the slope stability modeling results are discussed.

\subsection{Soil Testing}

Below is a table summarizing all the results of soil testing. Table 6.1 summarizes all of the soil properties that were run with multiple tests. Table 6.2 summarizes the tests run at different compaction energies. The tables give the average value for the property and the standard deviation ( $\mathrm{s}$ ) and coefficient of variation (COV) of the data.

Table 6.1: Soil property results with multiple tests

\begin{tabular}{|c|c|c|c|c|}
\hline Test & No. of Tests & Avg & s & COV \\
\hline Moisture Content (\%) & 3 & 2.78 & 0.145 & 0.052 \\
\hline Specific Gravity & 6 & 2.69 & 0.078 & 0.029 \\
\hline Uniformity Coefficient (\%) & 2 & 22.885 & 2.992 & 0.131 \\
\hline Coefficient of Gradation (\%) & 2 & 0.851 & 0.015 & 0.018 \\
\hline Liquid Limit & 2 & 19.2 & 0.141 & 0.02 \\
\hline Plastic Index & 2 & 2.85 & 0.354 & 0.125 \\
\hline
\end{tabular}


Table 6.2: Soil property results of tests run at different compaction energies

\begin{tabular}{|c|c|c|c|c|}
\hline \multirow[b]{2}{*}{ Property } & & \multicolumn{3}{|c|}{ Compaction Effort } \\
\hline & & Standard Proctor & $\begin{array}{c}34 \% \text { of } \\
\text { Standard } \\
\text { Proctor }\end{array}$ & $\begin{array}{l}11 \% \text { of } \\
\text { Standard } \\
\text { Proctor }\end{array}$ \\
\hline $\begin{array}{l}\text { Optimum } \\
\text { Dry Density } \\
\left(\mathrm{kN} / \mathrm{m}^{3}\right)\end{array}$ & & 18.75 & 18.1 & 14.9 \\
\hline $\begin{array}{c}\text { Optimum } \\
\text { Water } \\
\text { Content (\%) }\end{array}$ & & 10.75 & 14.5 & 9.75 \\
\hline $\begin{array}{c}\text { Cohesion } \\
(\mathrm{kPa})\end{array}$ & & 28.855 & 61.64 & 18.518 \\
\hline $\begin{array}{l}\text { Angle of } \\
\text { Friction } \\
\text { (degrees) }\end{array}$ & & 27.14 & 22.77 & 25.112 \\
\hline \multirow{4}{*}{$\begin{array}{l}\text { Hydraulic } \\
\text { Conductivity } \\
(\mathrm{m} / \mathrm{s})\end{array}$} & $\begin{array}{l}\text { No. of } \\
\text { Tests }\end{array}$ & 3 & 3 & 3 \\
\hline & Avg & $1.18 \mathrm{E}-09$ & 2.31E-09 & 2.64E-09 \\
\hline & $\mathrm{s}$ & $6.20 \mathrm{E}-10$ & $8.58 \mathrm{E}-10$ & $8.74 \mathrm{E}-10$ \\
\hline & $\mathrm{COV}$ & 0.314 & 0.544 & 0.544 \\
\hline
\end{tabular}

Using the properties and United Soil Classification System (USCS), the material was classified as well graded sand (SW).

\subsection{Groundwater Seepage Results}

The following section discusses the results of groundwater seepage modeling using SEEP/W. First the individual criteria by which the fills were analyzed are defined. Next, how to interpret the visual results of modeling profiles is explained. Then, visual and tabular results are organized and presented. Finally, the results for the AOC fill and geomorphic fill are compared in order to obtain any significant findings. 


\subsubsection{Criteria for Analysis}

In order to analyze the AOC and geomorphic fill on a year-to-year basis for each of the 10 years, parametNiers had to be chosen by which to analyze and compare. These parameters included:

- Minimum and maximum pore-water pressure $(\mathrm{kPa})$ : This parameter defined how the seepage created pressure within the fill as a result of the buildup of water.

- Water velocity $(\mathrm{m} / \mathrm{s})$ and water flux $\left(\mathrm{m}^{3} / \mathrm{s}\right)$ at the toe of the fill: These two parameters defined the movement of water at the toe of the fill, both as a seepage flow rate and a flux of volume of water through the cross-section of the toe.

- Maximum hydraulic velocity $(\mathrm{m} / \mathrm{s})$ within the fill: This defined the fastest rate at which water was traveling through any point in the fill at any given time.

- Storage $\left(\mathrm{m}^{3}\right)$ of water in the fill: Storage was the amount of water that was retained in the fill over time. During the solving process, SEEP/W recorded the water storage in the fill in cubic meters by subtracting the volume of water exiting the boundaries of the model from the volume of water entering the boundaries of the model. In its simplest definition, storage is inflow minus outflow. Using this storage value, along with the calculated volume of residual water in the fill before infiltration, the amount of infiltrating water that is stored was calculated.

The AOC and geomorphic fill modeled each had their own volume of fill material. The AOC fill had a fill volume of 72,632 $\mathrm{m}^{3}$, whereas the geomorphic fill had a fill volume of 55,403 $\mathrm{m}^{3}$. Since the behavior of groundwater seepage was dependent on the amount of fill material, each criterion was normalized by dividing the result by the fill's respective fill volume. This provided results that could be compared directly between the two fills. These criteria were used to develop results summary tables for each fill design and to then graphically compare the two fills over time.

\subsubsection{Visual Results}

After the model was run, visual profile results were produced for each time step. An explanation of what the components of these profile results mean is presented in this section. The shaded contours of each result showed levels of pore-water pressure. Higher pore-water pressure was 
depicted by a darker shade. Contours for pore-water pressure ranged from minimum to maximum pore-water pressure $(\mathrm{kPa})$ and use an interval of $200 \mathrm{kPa}$ for each contour. The dotted line within the fill showed the transition from negative pore-pressure to positive pore-pressure. Within the dotted line were zones with positive pore-pressure. These were the saturated zones within the fill. Water flow was depicted by black vectors. Larger vectors indicated faster water flow. For each model's results, the maximum vector length was kept at $15 \mathrm{~mm}$ in order to visually compare the different cases. Profiles with these visual results are shown within each fill design's results section. In the AOC design section, these are Figures $6.1-6.10$. In the geomorphic design section, these are Figures $6.11-6.20$.

\subsubsection{AOC Fill Design}

For the AOC fill, the total volume of the fill material was found to be $72,632 \mathrm{~m}^{3}$ and the total volume of the drain material was found to be $4,487 \mathrm{~m}^{3}$. The volume of water infiltrating into the fill was calculated using both the $85 \%$ and $55 \%$ infiltration functions. For each day in the yearly function, the depth of infiltrating water in the $85 \%$ infiltration case was multiplied by the length of the top of the fill surface $(402.2 \mathrm{~m})$ and by a $1 \mathrm{~m}$ thickness. This resulted in an infiltration volume of $2197 \mathrm{~m}^{3}$ per year for each of the 10 years. In the same way, the depth of infiltrating water in each day of the $55 \%$ case was multiplied by the length of the sloped portion of the fill surface $(741 \mathrm{~m})$ and by a $1 \mathrm{~m}$ thickness. This resulted in an infiltration volume of $6,260 \mathrm{~m}^{3}$ per year for each of the 10 years. Combining these values resulted in a total infiltration volume of $8,457 \mathrm{~m}^{3}$ each year. Calculating the residual water in the fill before infiltration required the use of the residual water content of the fill and the blocky core drain. For the fill material, a residual water content of $2.78 \%$ (taken from the moisture content soil testing) was multiplied by the fill volume of 72,632 $\mathrm{m}^{3}$ to result in a residual water volume of $2,019 \mathrm{~m}^{3}$. The drain was modeled in a saturated only condition with a saturated water content of $50 \%$, so the drain's total volume $\left(4,618 \mathrm{~m}^{3}\right)$ was multiplied by $50 \%$ to get a residual water volume of $2,309 \mathrm{~m}^{3}$. These two values

combined resulted in a total residual water volume of $4,328 \mathrm{~m}^{3}$. The residual water volume was subtracted from the total water in the fill (from SEEP/W) to get the actual storage volume within the fill. 
The majority of flow was both within the core drain and in the saturated zone above the core drain. Water within the drain caused a negative pore-pressure in the area above the drain and below the saturated zone. As the zone between the drain and the saturated zone dissipated water, negative pore pressure kept the saturated zone in tension and at a level above the drain. For the AOC fill, the negative pore pressure above the drain ranged from approximately $-150 \mathrm{kPa}$ to $740 \mathrm{kPa}$. Over time, the level of saturation lowered towards the level of the drain. Figures $6.1-$ 6.10 show the profile results for the AOC fill over time.

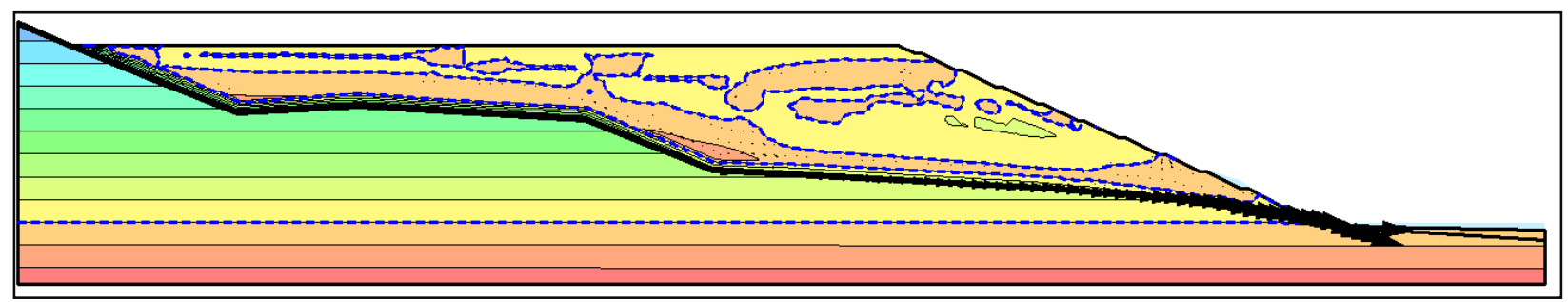

Figure 6.1: AOC fill profile seepage results - year 1

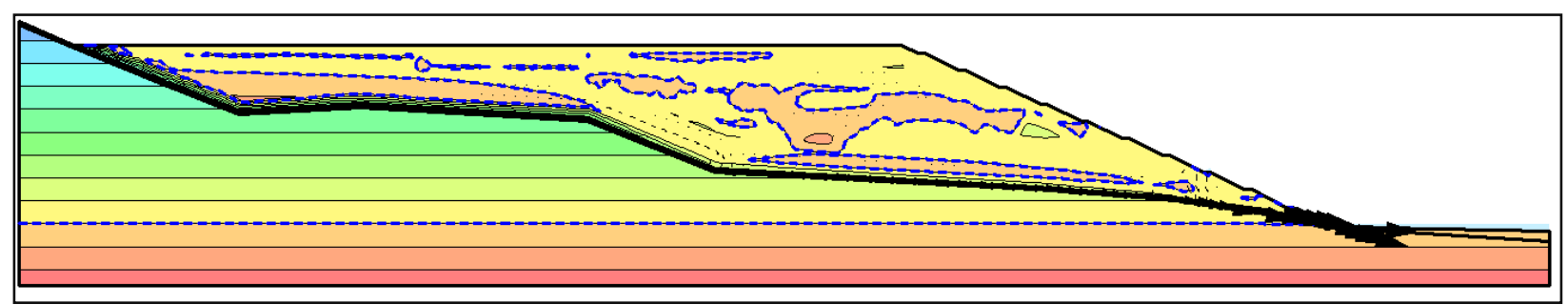

Figure 6.2: AOC fill profile seepage results - year 2

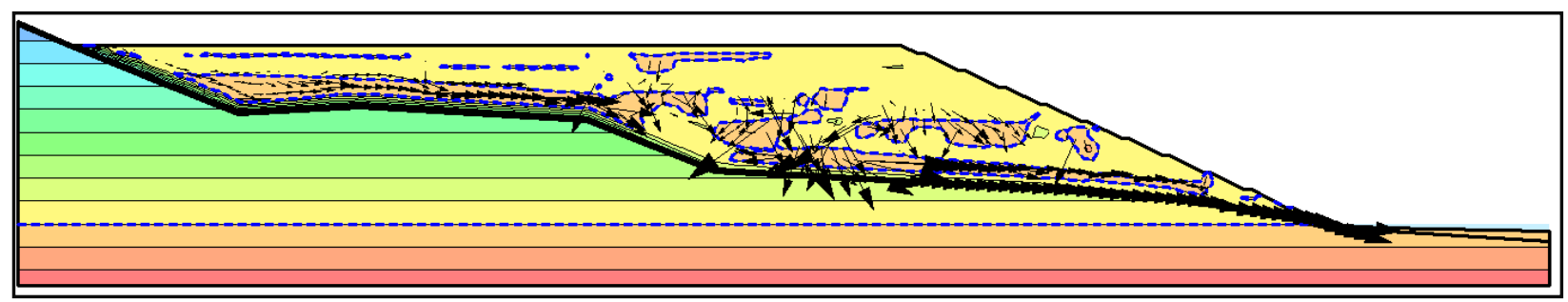

Figure 6.3: AOC fill profile seepage results - year 3 


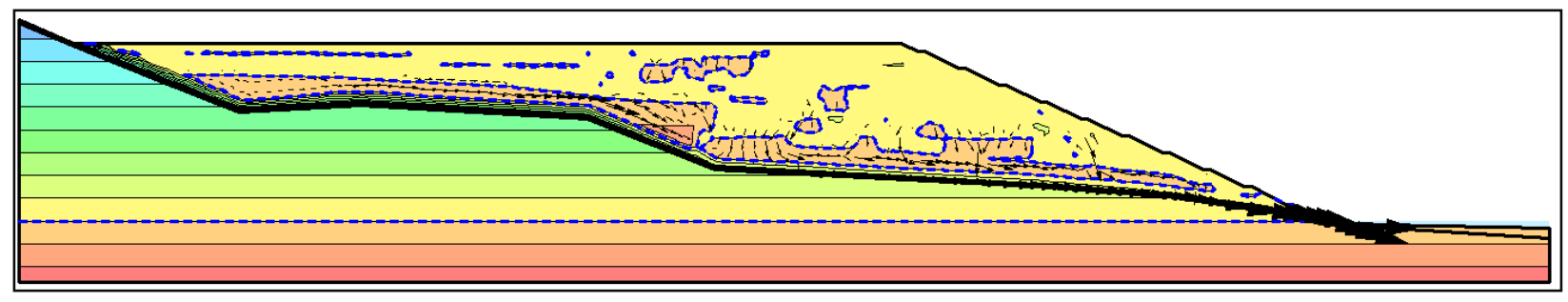

Figure 6.4: AOC fill profile seepage results-year 4

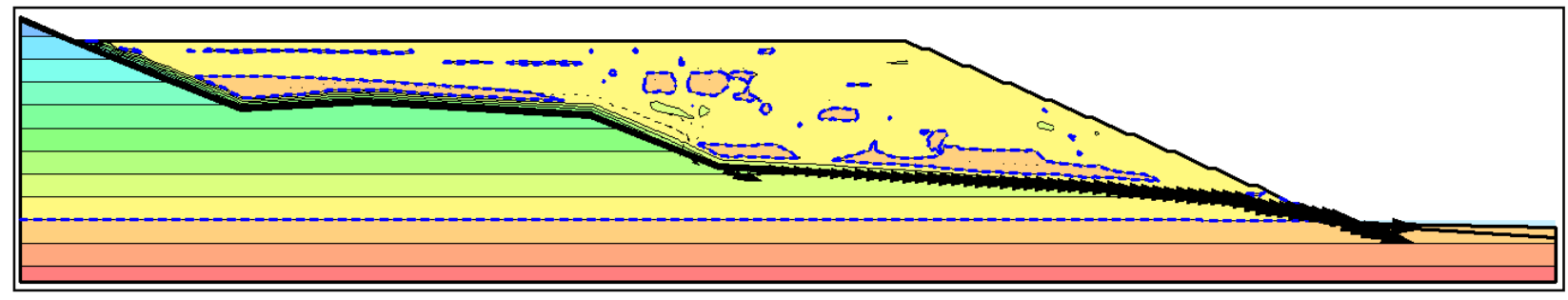

Figure 6.5: AOC fill profile seepage results - year 5

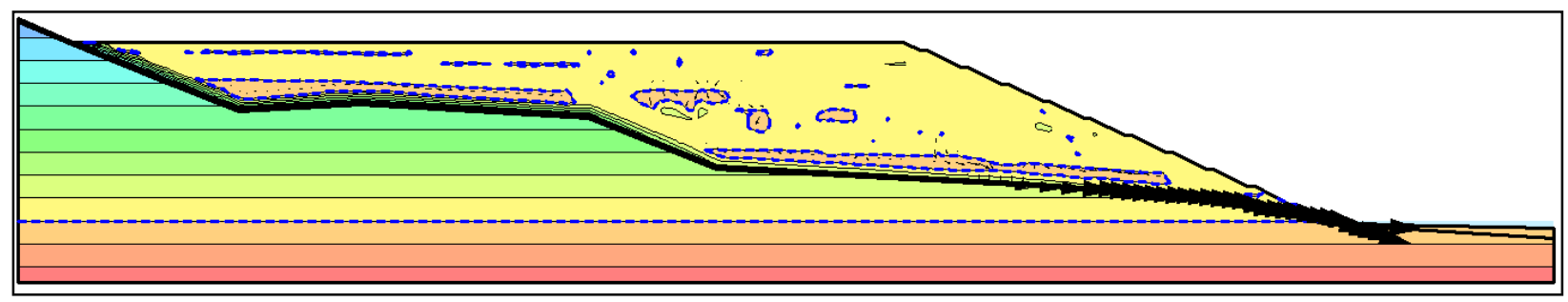

Figure 6.6: AOC fill profile seepage results - year 6

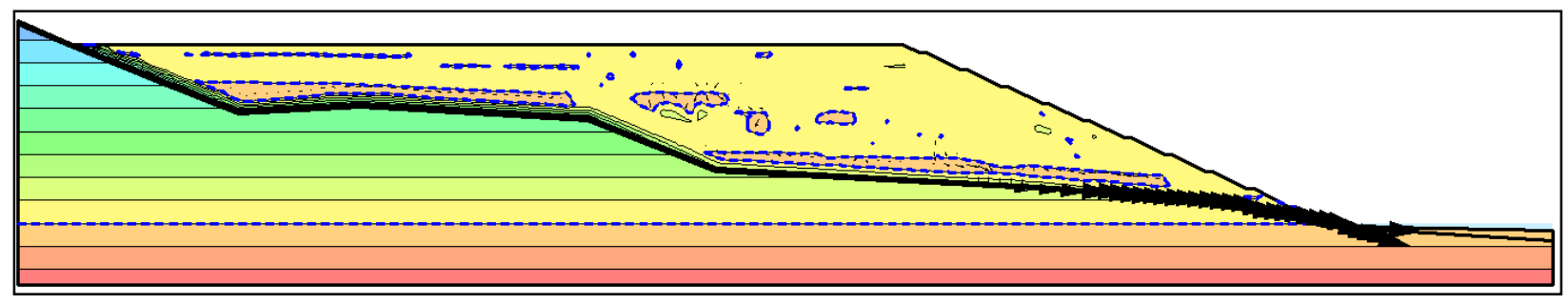

Figure 6.7: AOC fill profile seepage results - year 7 


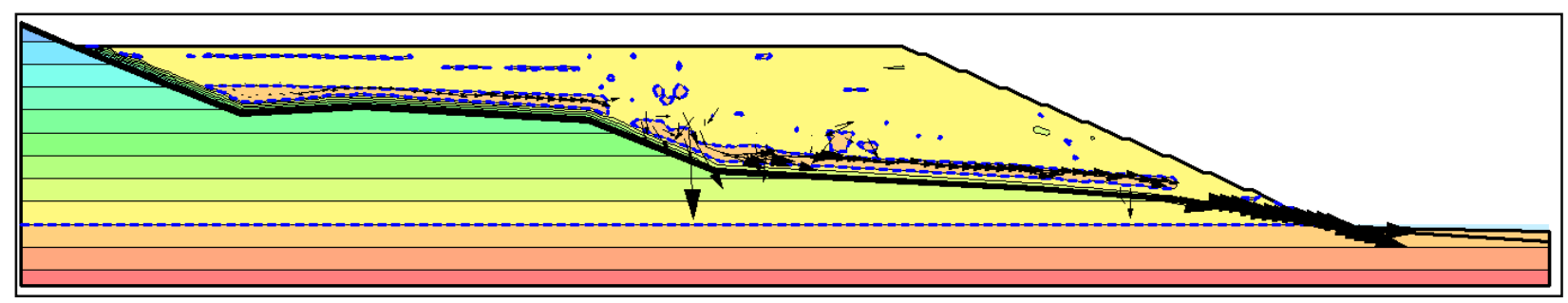

Figure 6.8: AOC fill profile seepage results - year 8

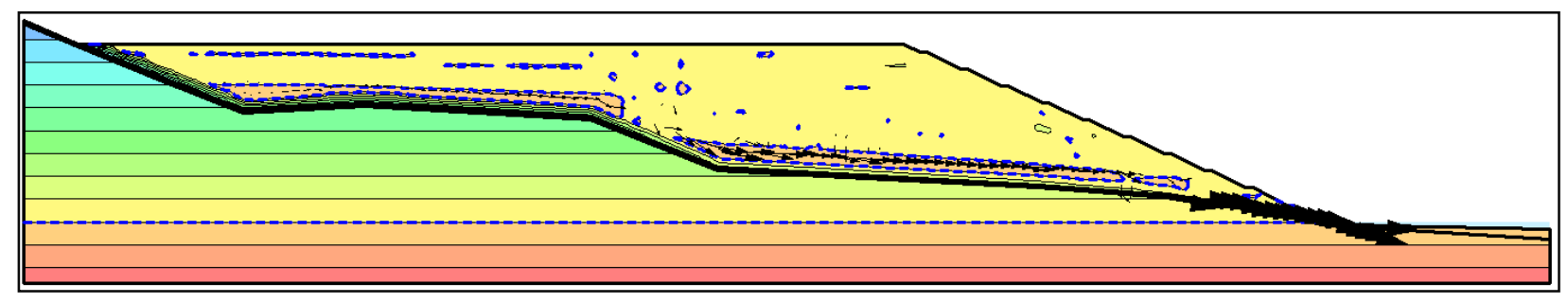

Figure 6.9: AOC fill profile seepage results - year 9

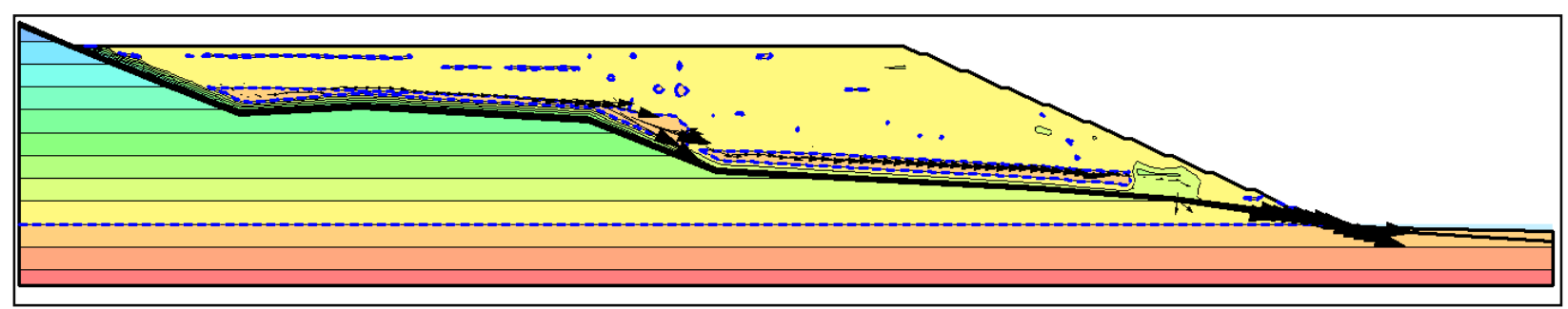

Figure 6.10: AOC fill profile seepage results - year 10

Over time, the level of saturation lowered towards the level of the drain. Table 6.3 below summarizes the normalized results (per $\mathrm{m}^{3}$ of fill) for the AOC fill over years 1-10. 
Table 6.3: AOC fill normalized seepage results - years 1-10

\begin{tabular}{|c|c|c|c|c|c|c|c|}
\hline $\begin{array}{c}\text { Time } \\
(\mathrm{yr})\end{array}$ & $\begin{array}{c}\text { Min Pore- } \\
\text { water Pressure } \\
\left(\mathrm{kPa} / \mathrm{m}^{3}\right)\end{array}$ & $\begin{array}{c}\text { Max Pore- } \\
\text { water Pressure } \\
\left(\mathrm{kPa} / \mathrm{m}^{3}\right)\end{array}$ & $\begin{array}{c}\text { Velocity } \\
\text { at Toe } \\
\left(\mathrm{m} / \mathrm{s} / \mathrm{m}^{3}\right)\end{array}$ & $\begin{array}{c}\text { Water Flux } \\
\text { at Toe } \\
\left(\mathrm{m}^{3} / \mathrm{s} / \mathrm{m}^{3}\right)\end{array}$ & $\begin{array}{c}\text { Max Hydraulic } \\
\text { Velocity } \\
\left(\mathrm{m} / \mathrm{s} / \mathrm{m}^{3}\right)\end{array}$ & $\begin{array}{c}\text { Total } \\
\text { Water in } \\
\text { Fill } \\
\left(\mathrm{m}^{3} / \mathrm{m}^{3}\right)\end{array}$ & $\begin{array}{c}\text { Storage } \\
\left(\mathrm{m}^{3} / \mathrm{m}^{3}\right)\end{array}$ \\
\hline 1 & -1758 & 543.7 & $1.16 \mathrm{E}-10$ & $5.40 \mathrm{E}-09$ & $1.85868 \mathrm{E}-09$ & 0.15767 & 9.8 \\
\hline 2 & -1761 & 540.9 & $8.73 \mathrm{E}-12$ & $3.46 \mathrm{E}-09$ & $1.1868 \mathrm{E}-09$ & 0.21862 & 15.9 \\
\hline 3 & -1763 & 538.4 & $4.96 \mathrm{E}-13$ & $4.75 \mathrm{E}-11$ & $1.96883 \mathrm{E}-11$ & 0.22015 & 16.1 \\
\hline 4 & -1763 & 538.5 & $1.09 \mathrm{E}-12$ & $1.57 \mathrm{E}-10$ & $5.41084 \mathrm{E}-11$ & 0.22204 & 16.2 \\
\hline 5 & -1761 & 540.3 & $5.18 \mathrm{E}-12$ & $1.61 \mathrm{E}-09$ & $5.56229 \mathrm{E}-10$ & 0.28127 & 22.2 \\
\hline 6 & -1763 & 538.6 & $1.37 \mathrm{E}-12$ & $2.20 \mathrm{E}-10$ & $7.61372 \mathrm{E}-11$ & 0.2891 & 23.0 \\
\hline 7 & -1763 & 538.4 & $4.31 \mathrm{E}-13$ & $3.91 \mathrm{E}-11$ & $1.3534 \mathrm{E}-11$ & 0.28823 & 22.9 \\
\hline 8 & -1763 & 538.4 & $4.52 \mathrm{E}-13$ & $4.20 \mathrm{E}-11$ & $1.44564 \mathrm{E}-11$ & 0.28649 & 22.7 \\
\hline 9 & -1763 & 538.4 & $6.62 \mathrm{E}-13$ & $7.48 \mathrm{E}-11$ & $2.58839 \mathrm{E}-11$ & 0.29 & 23.0 \\
\hline 10 & -1763 & 538.4 & $5.12 \mathrm{E}-13$ & $5.09 \mathrm{E}-11$ & $1.87245 \mathrm{E}-11$ & 0.29169 & 23.2 \\
\hline
\end{tabular}

Over time, minimum and maximum pore-water pressure remained relatively constant. Velocity at the toe, water flux at the toe, and max hydraulic velocity all decreased rapidly at the beginning. They remained relatively constant for the remainder of the model except for all three experiencing a spike in magnitude at year 5. Storage increased in spikes in years 2 and 5 while remaining relatively constant for other time steps.

\subsubsection{Geomorphic Fill Design}

For the geomorphic fill, the total volume of the fill material was found to be $55,403 \mathrm{~m}^{3}$ and the total volume of the drain material was found to be $4,487 \mathrm{~m}^{3}$. The volume of water infiltrating into the fill was calculated using the $55 \%$ infiltration function. For each day in the yearly function, the depth of infiltrating water was multiplied by the length of the fill surface $(1,356.5$ $\mathrm{m})$ and by a $1 \mathrm{~m}$ thickness. This resulted in an infiltration volume of 7,411 $\mathrm{m}^{3}$ per year for each of the 10 years. Calculating the residual water in the fill before infiltration required the use of the residual water content of the fill and the blocky core drain. For the fill material, a residual water content of $2.78 \%$ was multiplied by the fill volume of $55,403 \mathrm{~m}^{3}$ to result in a residual water volume of $1,540 \mathrm{~m}^{3}$. The drain resulted in the same residual water volume as in the AOC fill, since its geometry and water content were the same. These two values combined resulted in a total residual water volume of $3,849 \mathrm{~m}^{3}$. The residual water volume was subtracted from the total water in the fill (from SEEP/W) to get the actual storage volume within the fill. 
The same hydraulic behavior within the fill occurred in the geomorphic fill as in the AOC fill. Water within the drain caused a negative pore-pressure above the drain. For the geomorphic fill, the negative pore pressure above the drain ranged from approximately $-170 \mathrm{kPa}$ to $-1000 \mathrm{kPa}$. Over time, the level of saturation lowered towards the level of the drain. Figures $6.11-6.20$ show the fill profile results of the geomorphic fill for each year.

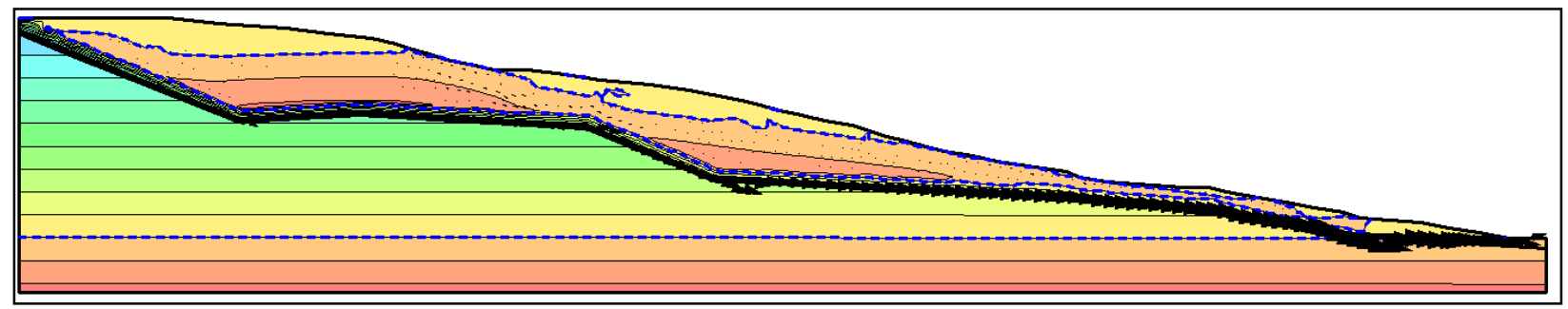

Figure 6.11: Geomorphic fill profile seepage results - year 1

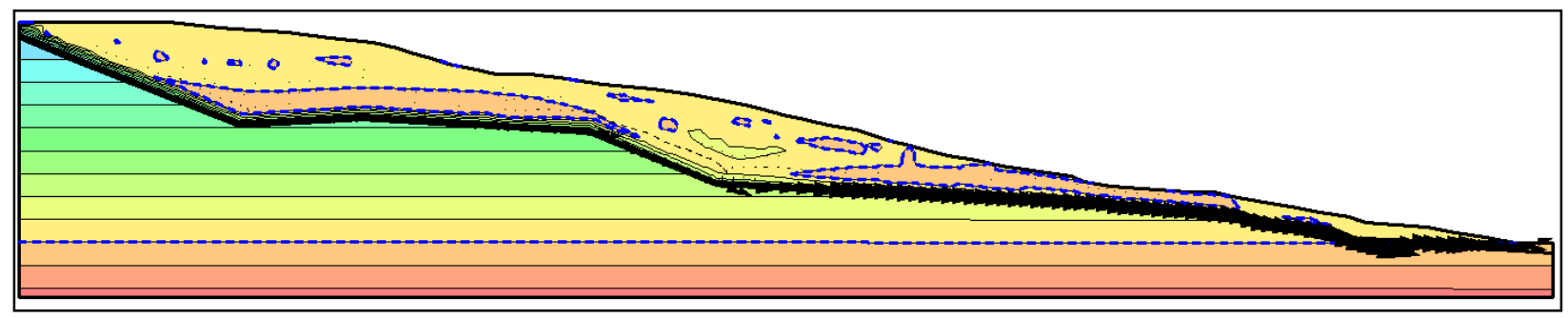

Figure 6.12: Geomorphic fill profile seepage results - year 2

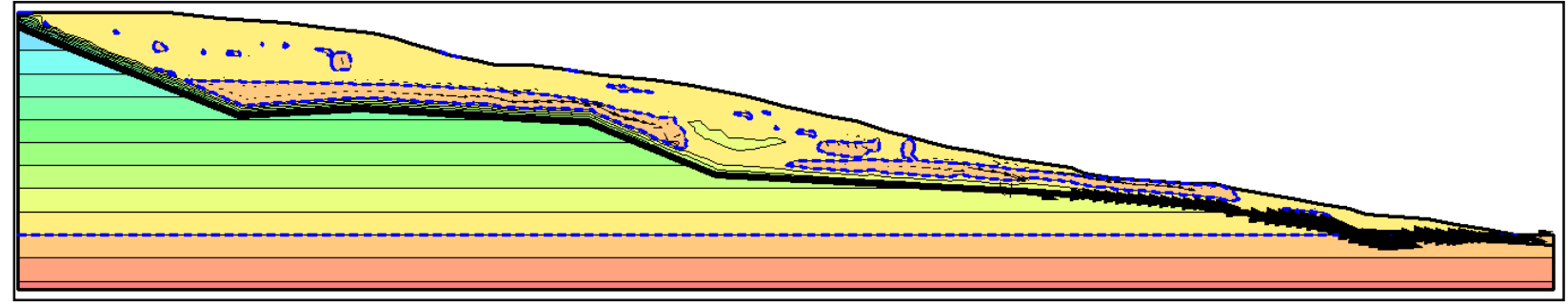

Figure 6.13: Geomorphic fill profile seepage results - year 3 


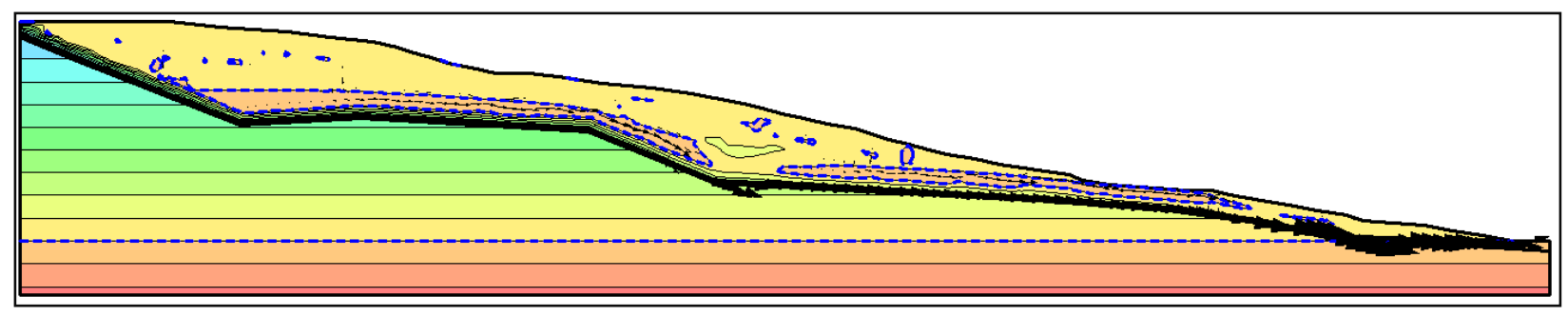

Figure 6.14: Geomorphic fill profile seepage results - year 4

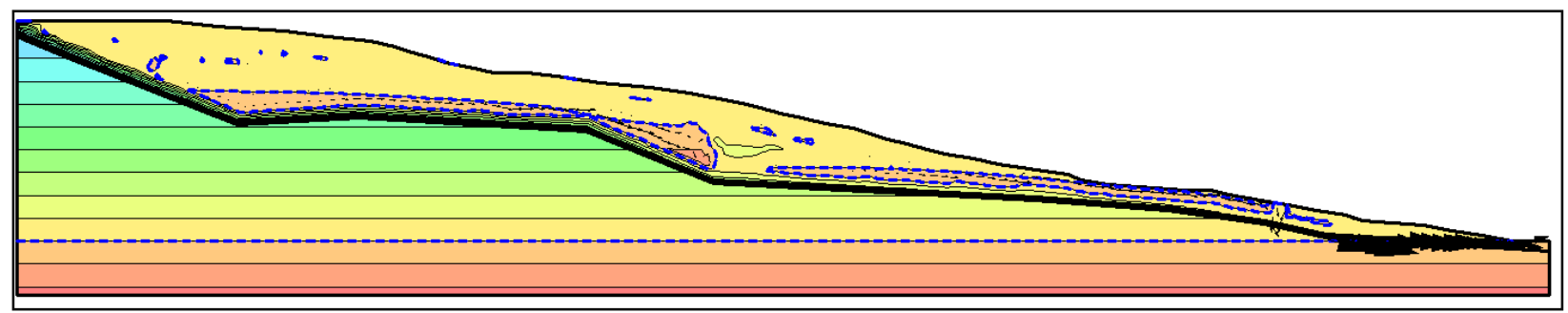

Figure 6.15: Geomorphic fill profile seepage results - year 5

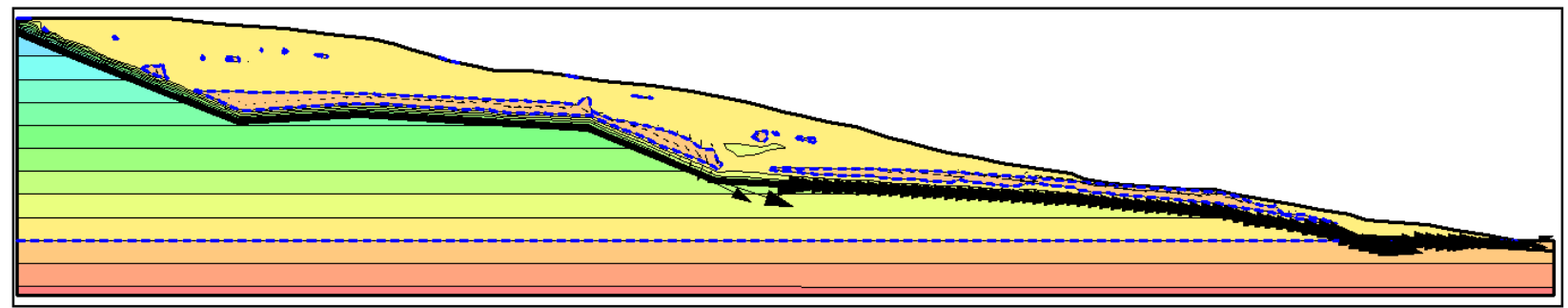

Figure 6.16: Geomorphic fill profile seepage results - year 6

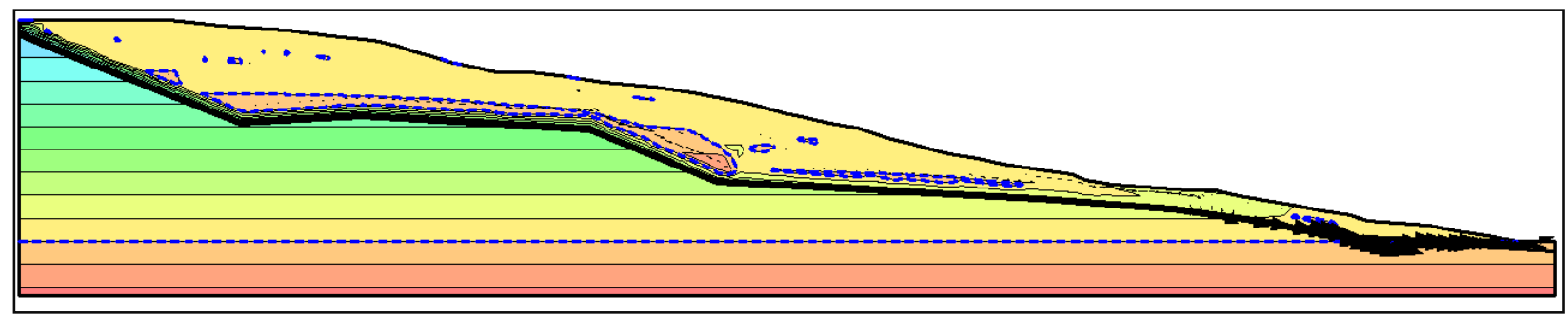

Figure 6.17: Geomorphic fill profile seepage results - year 7 


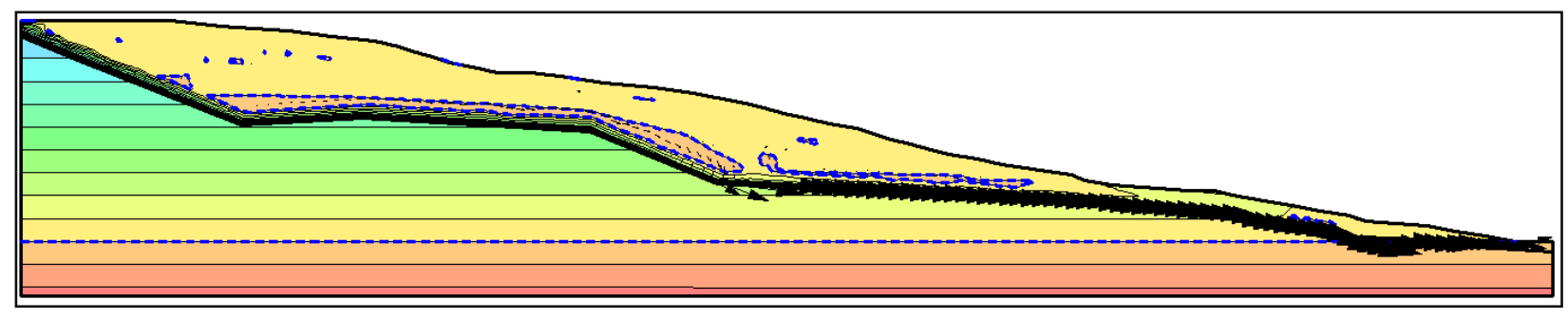

Figure 6.18: Geomorphic fill profile seepage results - year 8

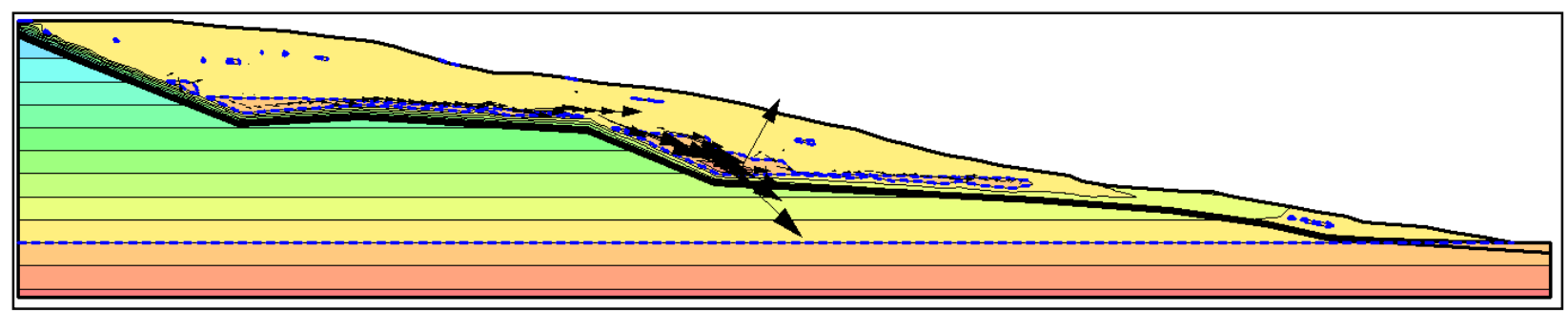

Figure 6.19: Geomorphic fill profile seepage results - year 9

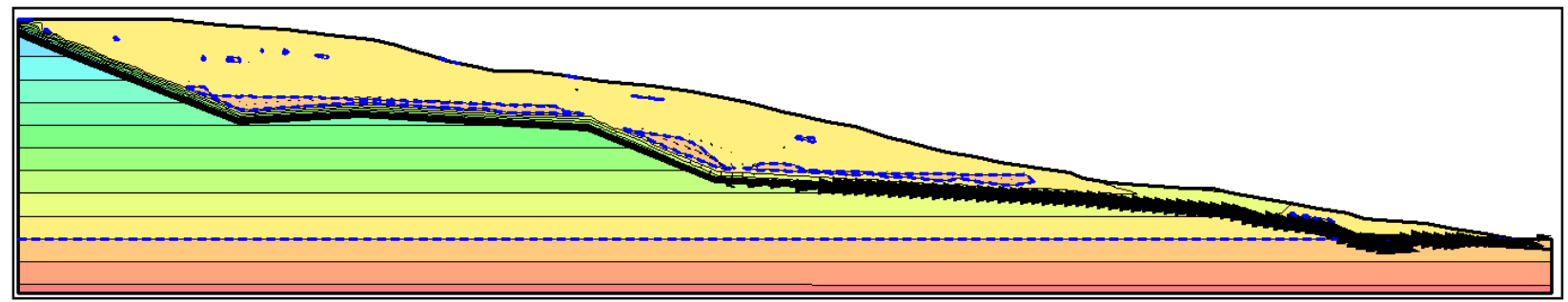

Figure 6.20: Geomorphic fill profile seepage results - year 10

The movement of the saturated zone within the geomorphic fill was similar to the movement within the AOC fill. Over time, the level of saturation lowered towards the level of the drain. This is because percentage of water stored in the fill decreased with time. Table 6.4 below summarizes the normalized results (per $\mathrm{m}^{3}$ of fill) for the geomorphic fill over years 1-10. 
Table 6.4: Geomorphic fill normalized seepage results - years 1-10

\begin{tabular}{|c|c|c|c|c|c|c|c|}
\hline $\begin{array}{c}\text { Time } \\
(\mathrm{yr})\end{array}$ & $\begin{array}{c}\text { Min Pore-water } \\
\text { Pressure } \\
\left(\mathrm{kPa} / \mathrm{m}^{3}\right)\end{array}$ & $\begin{array}{c}\text { Max Pore- } \\
\text { water Pressure } \\
\left(\mathrm{kPa} / \mathrm{m}^{3}\right)\end{array}$ & $\begin{array}{c}\text { Velocity } \\
\text { at Toe } \\
\left(\mathrm{m} / \mathrm{s} / \mathrm{m}^{3}\right)\end{array}$ & $\begin{array}{c}\text { Water Flux } \\
\text { at Toe } \\
\left(\mathrm{m}^{3} / \mathrm{s} / \mathrm{m}^{3}\right)\end{array}$ & $\begin{array}{c}\text { Max } \\
\text { Hydraulic } \\
\text { Velocity } \\
\left(\mathrm{m} / \mathrm{s} / \mathrm{m}^{3}\right)\end{array}$ & $\begin{array}{c}\text { Total } \\
\text { Water in } \\
\text { Fill } \\
\left(\mathrm{m}^{3 /} \mathrm{m}^{3}\right)\end{array}$ & $\begin{array}{c}\text { Storage } \\
\left(\mathrm{m}^{3 / 1} \mathrm{~m}^{3}\right)\end{array}$ \\
\hline 1 & -1817 & 485 & $3.61 \mathrm{E}-10$ & $4.71 \mathrm{E}-09$ & $1.74 \mathrm{E}-09$ & $1.73 \mathrm{E}-01$ & 7.9 \\
\hline 2 & -1817 & 485.1 & $4.37 \mathrm{E}-11$ & $4.21 \mathrm{E}-09$ & $1.60 \mathrm{E}-09$ & $2.67 \mathrm{E}-01$ & 15.1 \\
\hline 3 & -1823 & 478.5 & $6.89 \mathrm{E}-12$ & $2.40 \mathrm{E}-10$ & $1.15 \mathrm{E}-10$ & $2.79 \mathrm{E}-01$ & 16.0 \\
\hline 4 & -1823 & 478.6 & $6.17 \mathrm{E}-12$ & $2.83 \mathrm{E}-10$ & $1.08 \mathrm{E}-10$ & $2.89 \mathrm{E}-01$ & 16.8 \\
\hline 5 & -1823 & 478.4 & $7.13 \mathrm{E}-12$ & $3.86 \mathrm{E}-10$ & $1.47 \mathrm{E}-10$ & $2.91 \mathrm{E}-01$ & 16.9 \\
\hline 6 & -1823 & 478.6 & $5.32 \mathrm{E}-12$ & $2.69 \mathrm{E}-10$ & $1.03 \mathrm{E}-10$ & $2.97 \mathrm{E}-01$ & 17.4 \\
\hline 7 & -1823 & 478.5 & $7.53 \mathrm{E}-12$ & $4.86 \mathrm{E}-10$ & $1.86 \mathrm{E}-10$ & $3.16 \mathrm{E}-01$ & 18.8 \\
\hline 8 & -1823 & 478.6 & $4.26 \mathrm{E}-12$ & $2.20 \mathrm{E}-10$ & $8.41 \mathrm{E}-11$ & $3.21 \mathrm{E}-01$ & 19.2 \\
\hline 9 & -1823 & 478.3 & $1.21 \mathrm{E}-14$ & $3.43 \mathrm{E}-14$ & $1.86 \mathrm{E}-11$ & $3.22 \mathrm{E}-01$ & 19.3 \\
\hline 10 & -1823 & 478.6 & $4.26 \mathrm{E}-12$ & $2.47 \mathrm{E}-10$ & $9.48 \mathrm{E}-11$ & $3.34 \mathrm{E}-01$ & 20.1 \\
\hline
\end{tabular}

Over time, minimum and maximum pore-water pressure remained relatively constant. Velocity at the toe, water flux at the toe, and max hydraulic velocity all decreased rapidly at the beginning and then remained relatively constant for the remainder of the model. Storage had an initial sharp increase then increased slightly for the remainder of the model.

\subsubsection{Comparison of Results}

Once results for the AOC fill and geomorphic fill were collected, results were compared on a yearly basis with regards to chosen analysis criteria. For each year of the model, the result of each criterion for the AOC fill was compared directly to the same criterion for the geomorphic fill. Criteria chosen for comparison included pore-water pressure, water velocity at the toe of the fill, water flux at the toe of the fill, maximum hydraulic velocity within the fill, and storage. Many of the tables report a "percent change". This percent change calculated the difference between the geomorphic value and AOC value as a percentage of the AOC value. The percent change was calculated for each criterion at each time step by Equation 2 below:

$$
\text { Percent Change }(\%)=\frac{(\text { Geomorphic value }- \text { AOC value })}{\text { AOC value }} * 100
$$

Positive values indicated a point where the geomorphic fill had a property with higher magnitude than the AOC fill, while negative values indicted a point where the AOC fill had a property of 
higher magnitude than the geomorphic fill. This type of difference was chosen because a positive or negative difference could show an advantage of either the AOC or geomorphic fill, depending on what criterion was being compared. The advantage is in faster drainage through the fill as a result of higher seepage velocities and lower storage. Since the initial value was from the AOC model and the value of interest came from the geomorphic fill, calculating the change as a percentage of the AOC value best presented the magnitude of advantage for either fill. Also, a percent difference approach provided a common scale by which to compare the magnitude of the advantage of different analysis criteria. For instance, the magnitude of the advantage of one fill with respect to water velocity at the toe could be directly compared to the magnitude of the advantage of one fill with respect to storage. A higher percent change corresponded to a higher advantage to one fill.

With regards to water velocity at the toe, water flux at the toe, and maximum hydraulic velocity, higher values were more desirable. Higher values with respect to these criteria meant that the water was being moved through the fill at a faster rate. Faster water movement through the fill was advantageous because less water in the fill resulted in less chance of slope instability due to buildup of water and less contact time with the internal fill materials. The latter of these is important when analyzing contaminant transport because longer contact time with the material results in more contaminant desorption. Therefore, a positive difference was a time at which the geomorphic fill had an advantage over the AOC fill, and a negative difference related to an advantage for the AOC fill. With respect to storage, a lower value meant less water in the fill. This was more desirable for the same reasons as a faster water movement through the fill. A positive difference was a time at which the AOC fill had an advantage over the geomorphic fill, and a negative difference related to an advantage for the geomorphic fill.

\section{Pore-water Pressure}

Values for minimum and maximum pore-water pressure remained fairly constant for each fill over the 10 year modeling period. For this reason, an average value for minimum and maximum pore-water pressure was calculated for each fill. The results are summarized in Table 6.5 below. 
Table 6.5: Comparison of pore-water pressure results

\begin{tabular}{|c|c|c|c|}
\cline { 2 - 4 } \multicolumn{1}{c|}{} & \multicolumn{3}{c|}{ Pore-water Pressure (kPa) } \\
\hline Fill Type & Average Min & Average Max & Range \\
\hline AOC & -1762.1 & 539.4 & 2301.5 \\
\hline Geomorphic & -1821.8 & 479.82 & 2301.62 \\
\hline
\end{tabular}

The AOC fill had a minimum pore-water pressure of lower magnitude than the geomorphic fill, but had a maximum pore-water pressure of greater magnitude than the geomorphic fill. The range of pore-water pressure values for the two fills was almost equal. This is because the geomorphic fill did not alter the soil properties, so the same range of pore-water pressures occurred. For each fill, the fill material had the same soil-water characteristic curve, so the behavior of pore-water pressure over time was the same.

\section{Water Velocity at Toe}

The next criterion used for comparison was the velocity of water at the toe of the fill. The variation of normalized toe water velocity over time is summarized in Table 6.6 and plotted in Figures 6.21 and 6.22 below.

Table 6.6: Comparison of normalized toe water velocity results

\begin{tabular}{|c|c|c|c|}
\hline & \multicolumn{3}{|c|}{ Normalized Water Velocity at Toe $\left(\mathrm{m} / \mathrm{s} / \mathrm{m}^{3}\right)$} \\
\hline Time (yr) & AOC & Geomorphic & Percent Change (\%) \\
\hline 1 & $1.16 \mathrm{E}-10$ & $3.61 \mathrm{E}-10$ & 211.0 \\
\hline 2 & $8.73 \mathrm{E}-12$ & $4.37 \mathrm{E}-11$ & 400.4 \\
\hline 3 & $4.96 \mathrm{E}-13$ & $6.89 \mathrm{E}-12$ & 1291.1 \\
\hline 4 & $1.09 \mathrm{E}-12$ & $6.17 \mathrm{E}-12$ & 464.7 \\
\hline 5 & $5.18 \mathrm{E}-12$ & $7.13 \mathrm{E}-12$ & 37.7 \\
\hline 6 & $1.37 \mathrm{E}-12$ & $5.32 \mathrm{E}-12$ & 288.7 \\
\hline 7 & $4.31 \mathrm{E}-13$ & $7.53 \mathrm{E}-12$ & 1646.6 \\
\hline 8 & $4.52 \mathrm{E}-13$ & $4.26 \mathrm{E}-12$ & 843.3 \\
\hline 9 & $6.62 \mathrm{E}-13$ & $1.21 \mathrm{E}-14$ & -98.2 \\
\hline 10 & $5.12 \mathrm{E}-13$ & $4.26 \mathrm{E}-12$ & 731.7 \\
\hline
\end{tabular}




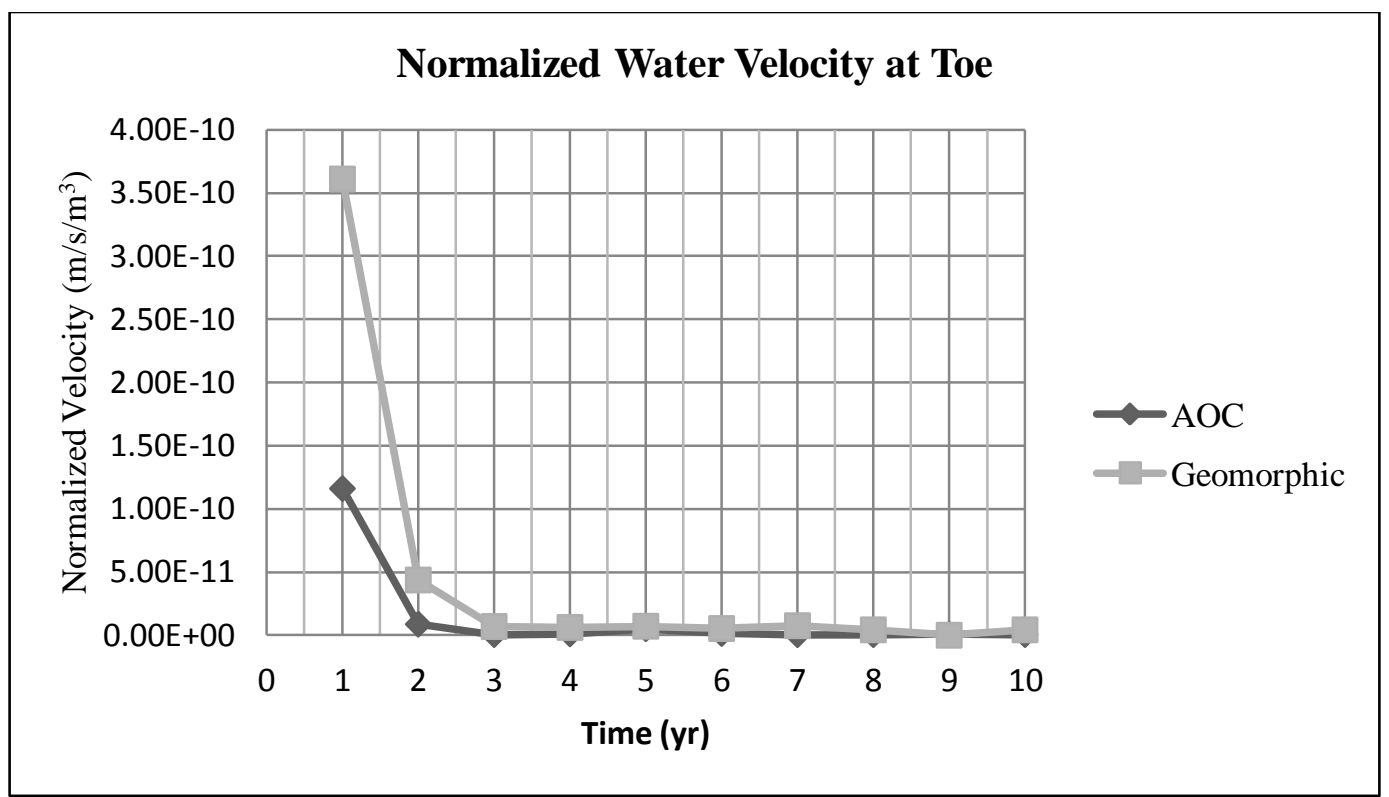

Figure 6.21: Normalized toe water velocity over time for both fills

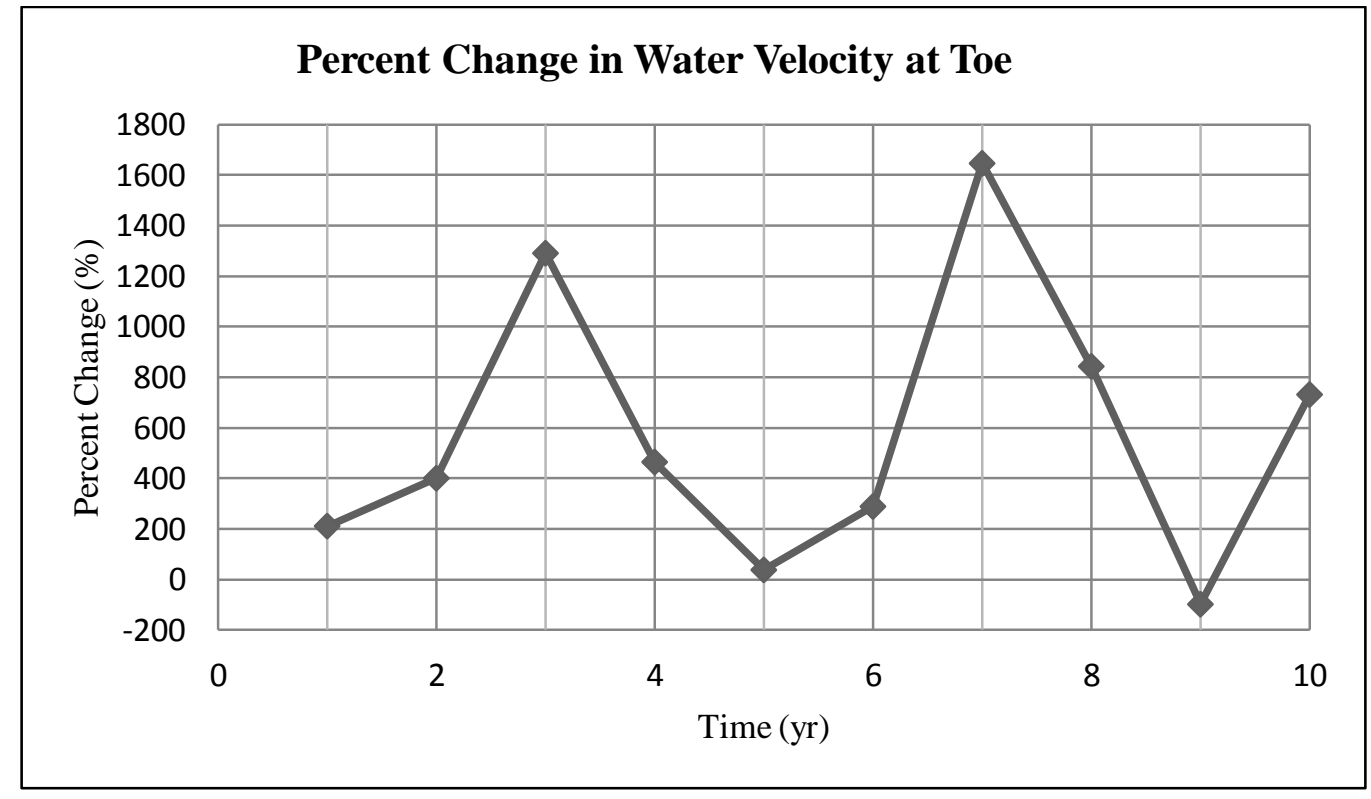

Figure 6.22: Percent change in water velocity at toe for AOC and geomorphic fills

The water velocity of the toe was lower for the AOC fill than for geomorphic fill for every year of the 10 year model except for year 9. Water velocity at the toe showed an advantage for the 
geomorphic fill for the entire duration other than a short time in year 9, where the AOC fill had a 98.2\% advantage. The geomorphic fill had peaks in advantage of $1291.1 \%$ at year 3 and $1646.6 \%$ at year 7 . The magnitude of the geomorphic fill's advantage was much higher than the advantage for the AOC fill. The advantage was a result of the geomorphic fill moving water through the fill at a faster rate, which is ideal when looking at slope stability and contaminant transport.

\section{Water Flux at Toe}

The next criterion used for comparison was the flux of water at the toe of the fill. This expressed the rate at which a given volume of water passed through the cross-section plane at the toe. The variation of normalized toe water flux over time is summarized in Table 6.7 and plotted in Figures 6.23 and 6.24 below.

Table 6.7: Comparison of normalized toe water flux results

\begin{tabular}{|c|c|c|c|}
\cline { 2 - 4 } \multicolumn{1}{c|}{} & \multicolumn{3}{|c|}{ Normalized Water Flux at Toe $\left(\mathrm{m}^{3} / \mathrm{s} / \mathrm{m}^{3}\right)$} \\
\hline Time $(\mathrm{yr})$ & AOC & Geomorphic & Percent Change $(\%)$ \\
\hline 1 & $5.40 \mathrm{E}-09$ & $4.71 \mathrm{E}-09$ & -12.7 \\
\hline 2 & $3.46 \mathrm{E}-09$ & $4.21 \mathrm{E}-09$ & 21.7 \\
\hline 3 & $4.75 \mathrm{E}-11$ & $2.40 \mathrm{E}-10$ & 405.4 \\
\hline 4 & $1.57 \mathrm{E}-10$ & $2.83 \mathrm{E}-10$ & 80.5 \\
\hline 5 & $1.61 \mathrm{E}-09$ & $3.86 \mathrm{E}-10$ & -76.0 \\
\hline 6 & $2.20 \mathrm{E}-10$ & $2.69 \mathrm{E}-10$ & 22.2 \\
\hline 7 & $3.91 \mathrm{E}-11$ & $4.86 \mathrm{E}-10$ & 1141.7 \\
\hline 8 & $4.20 \mathrm{E}-11$ & $2.20 \mathrm{E}-10$ & 424.4 \\
\hline 9 & $7.48 \mathrm{E}-11$ & $3.43 \mathrm{E}-14$ & -100.0 \\
\hline 10 & $5.09 \mathrm{E}-11$ & $2.47 \mathrm{E}-10$ & 385.4 \\
\hline
\end{tabular}




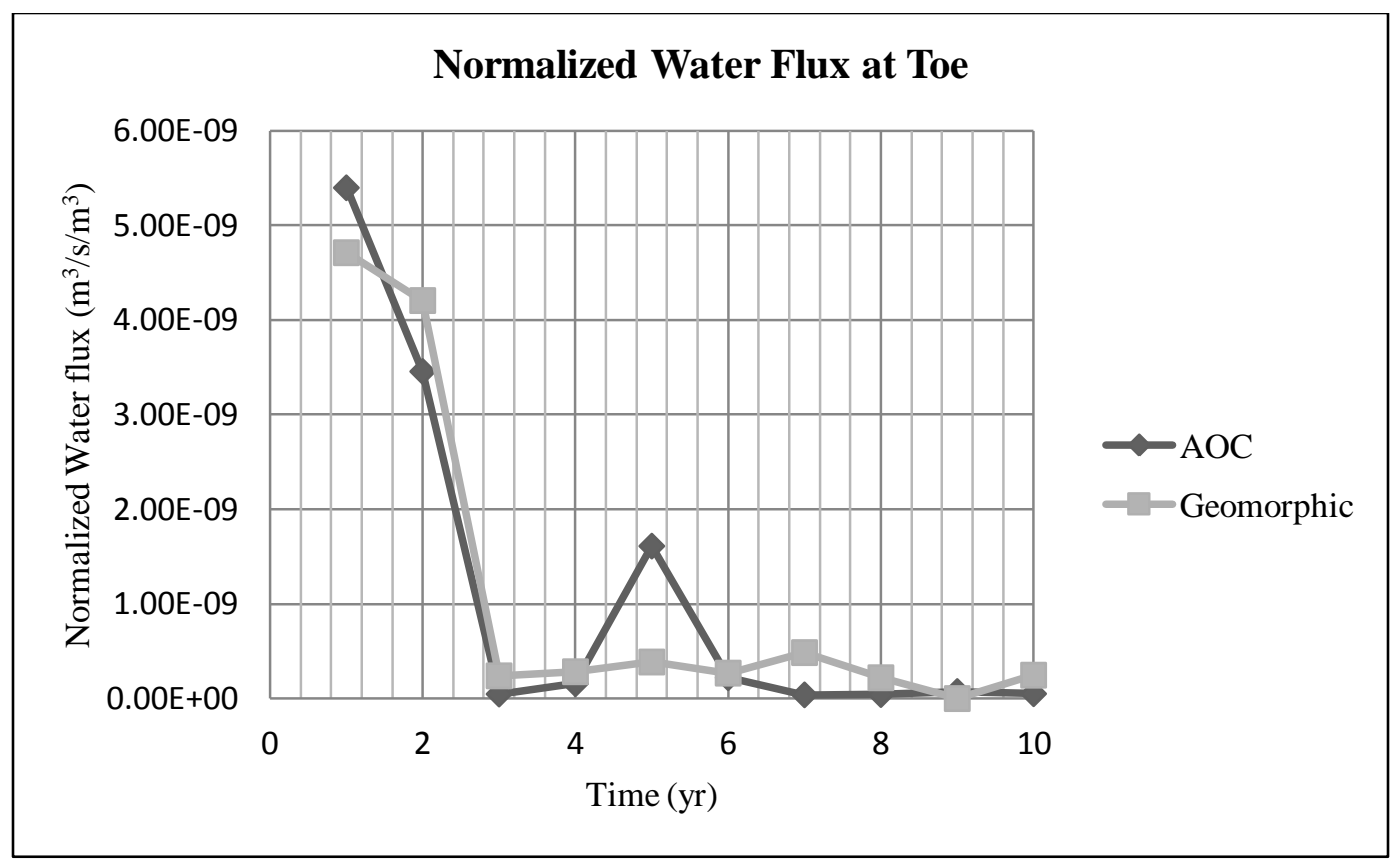

Figure 6.23: Normalized water flux at toe over time for both fills

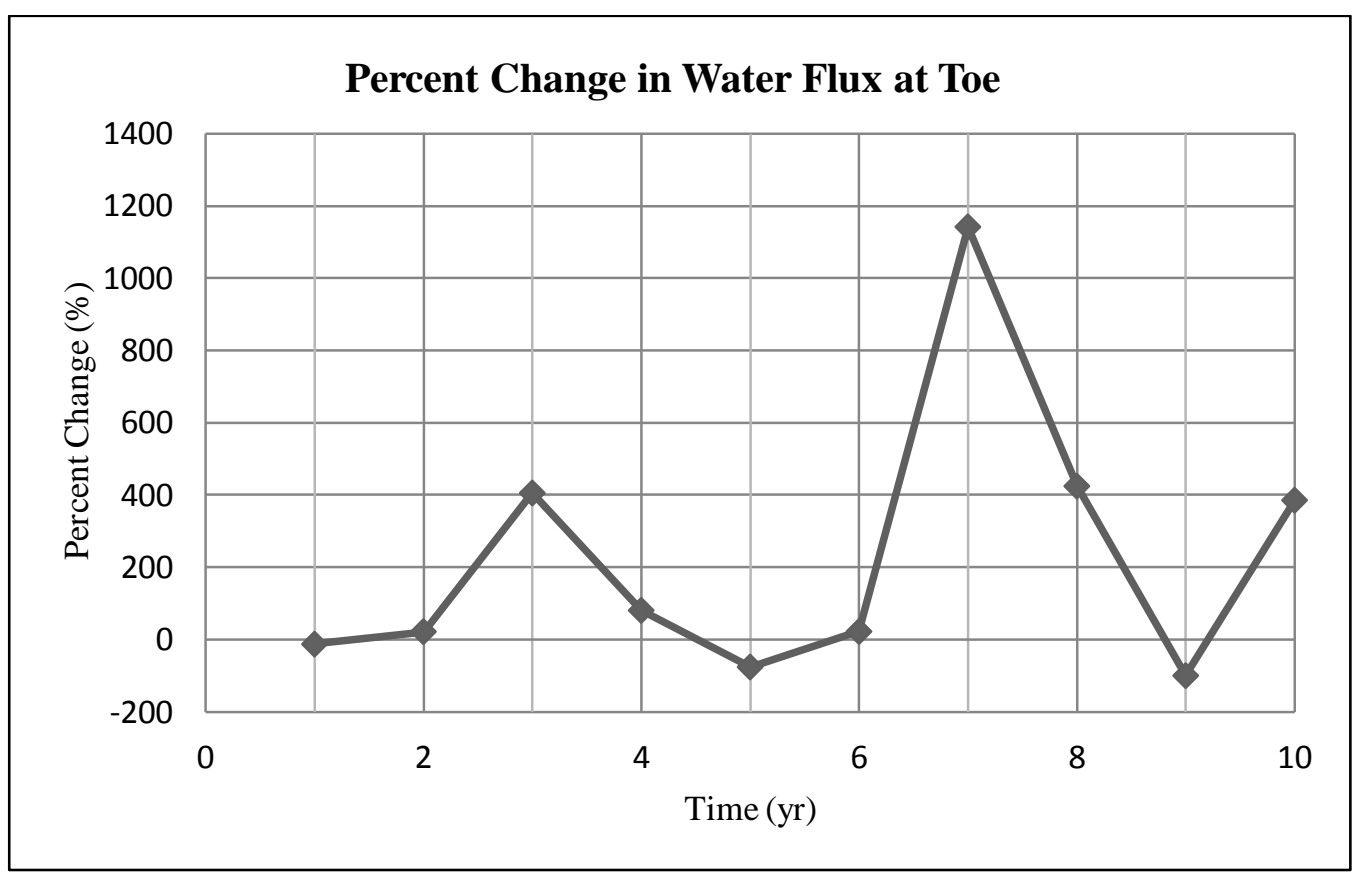

Figure 6.24: Percent change in water flux at toe for AOC and geomorphic fills 
The water flux at the toe of the AOC fill started at a higher magnitude than the geomorphic fill. By year 3, the flux of both fills reached a much lower value. Between years 3 through 10, the fluxes varied between one being of higher magnitude than the other. Year 5 showed a spike in the flux of the AOC fill, whereas the flux of the geomorphic fill stayed at a more stable rate through years 3 through 10 .

The AOC fill has an advantage over the geomorphic fill from years 1-2, 4-6, and 8.5-9.5 with peaks in its advantage of $76.0 \%$ at year 5 and $100.0 \%$ at year 9. The geomorphic fill is advantageous from years 2-4, 6-8.5, and 9.5-10 with its peaks in advantage of $405.4 \%$ at year 3 and $1141.7 \%$ at year 7 . The magnitude of the advantage for the geomorphic fill is much higher than the magnitude of the advantage for the AOC fill.

\section{Maximum Hydraulic Velocity}

The next criterion used for comparison was the maximum hydraulic velocity throughout the fill. This expressed the maximum velocity at which water was traveling within the fill for each year. The variation of normalized maximum hydraulic velocity over time is summarized in Table 6.8 and plotted in the Figures 6.25 and 6.26 below.

Table 6.8: Comparison of normalized maximum hydraulic velocity results

\begin{tabular}{|c|c|c|c|}
\cline { 2 - 4 } \multicolumn{1}{c|}{} & \multicolumn{3}{c|}{ Normalized Maximum Hydraulic Velocity $\left(\mathrm{m} / \mathrm{s} / \mathrm{m}^{3}\right)$} \\
\hline Time $(\mathrm{yr})$ & AOC & Geomorphic & Percent Change $(\%)$ \\
\hline 1 & $1.859 \mathrm{E}-09$ & $1.74 \mathrm{E}-09$ & -6.6 \\
\hline 2 & $1.19 \mathrm{E}-09$ & $1.60 \mathrm{E}-09$ & 35.1 \\
\hline 3 & $1.97 \mathrm{E}-11$ & $1.15 \mathrm{E}-10$ & 482.1 \\
\hline 4 & $5.41 \mathrm{E}-11$ & $1.08 \mathrm{E}-10$ & 99.5 \\
\hline 5 & $5.56 \mathrm{E}-10$ & $1.47 \mathrm{E}-10$ & -73.6 \\
\hline 6 & $7.61 \mathrm{E}-11$ & $1.03 \mathrm{E}-10$ & 34.9 \\
\hline 7 & $1.35 \mathrm{E}-11$ & $1.86 \mathrm{E}-10$ & 1273.7 \\
\hline 8 & $1.45 \mathrm{E}-11$ & $8.41 \mathrm{E}-11$ & 481.8 \\
\hline 9 & $2.59 \mathrm{E}-11$ & $1.86 \mathrm{E}-11$ & -28.2 \\
\hline 10 & $1.87 \mathrm{E}-11$ & $9.48 \mathrm{E}-11$ & 406.1 \\
\hline
\end{tabular}




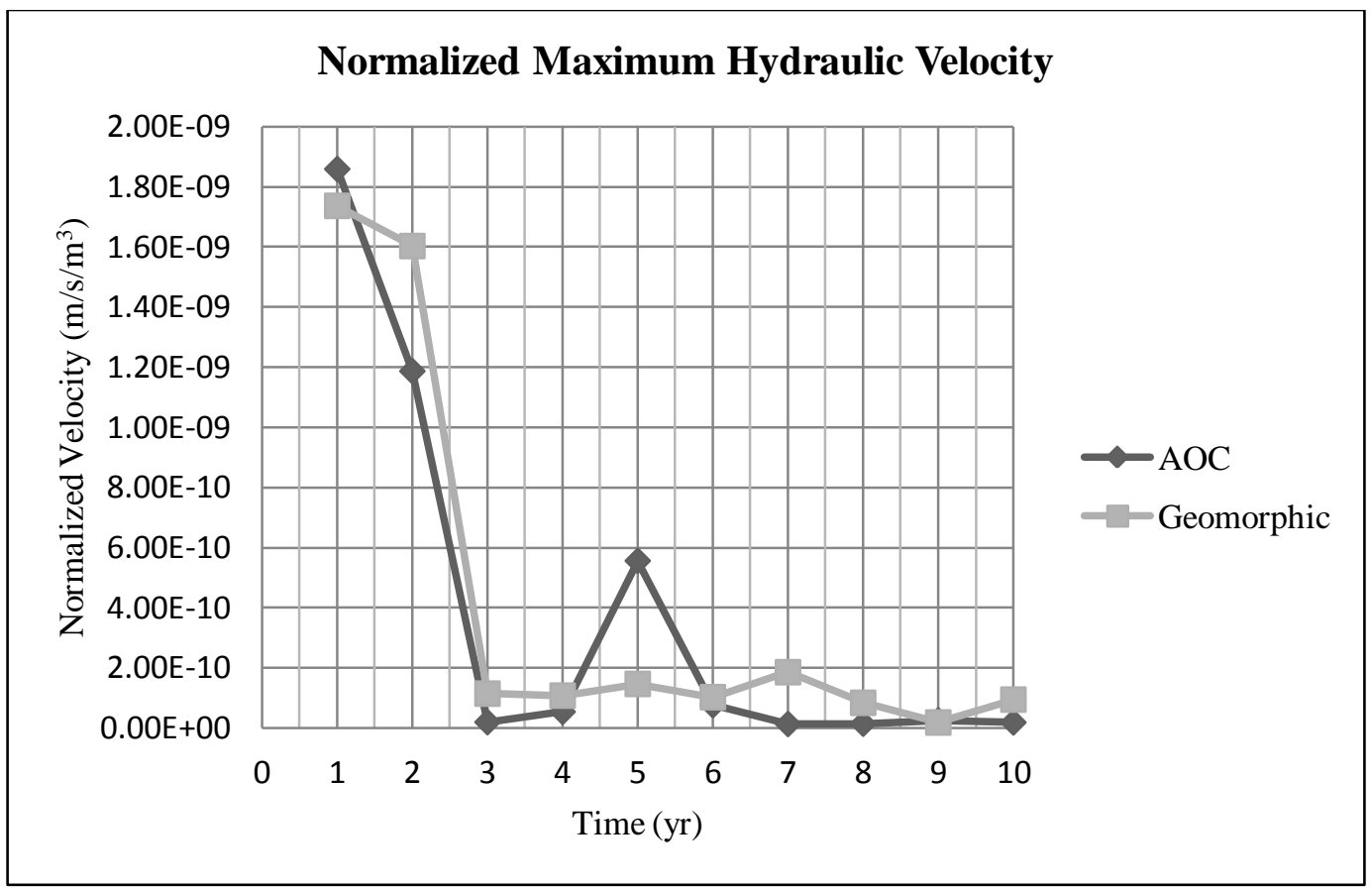

Figure 6.25: Normalized maximum hydraulic velocity over time for both fills

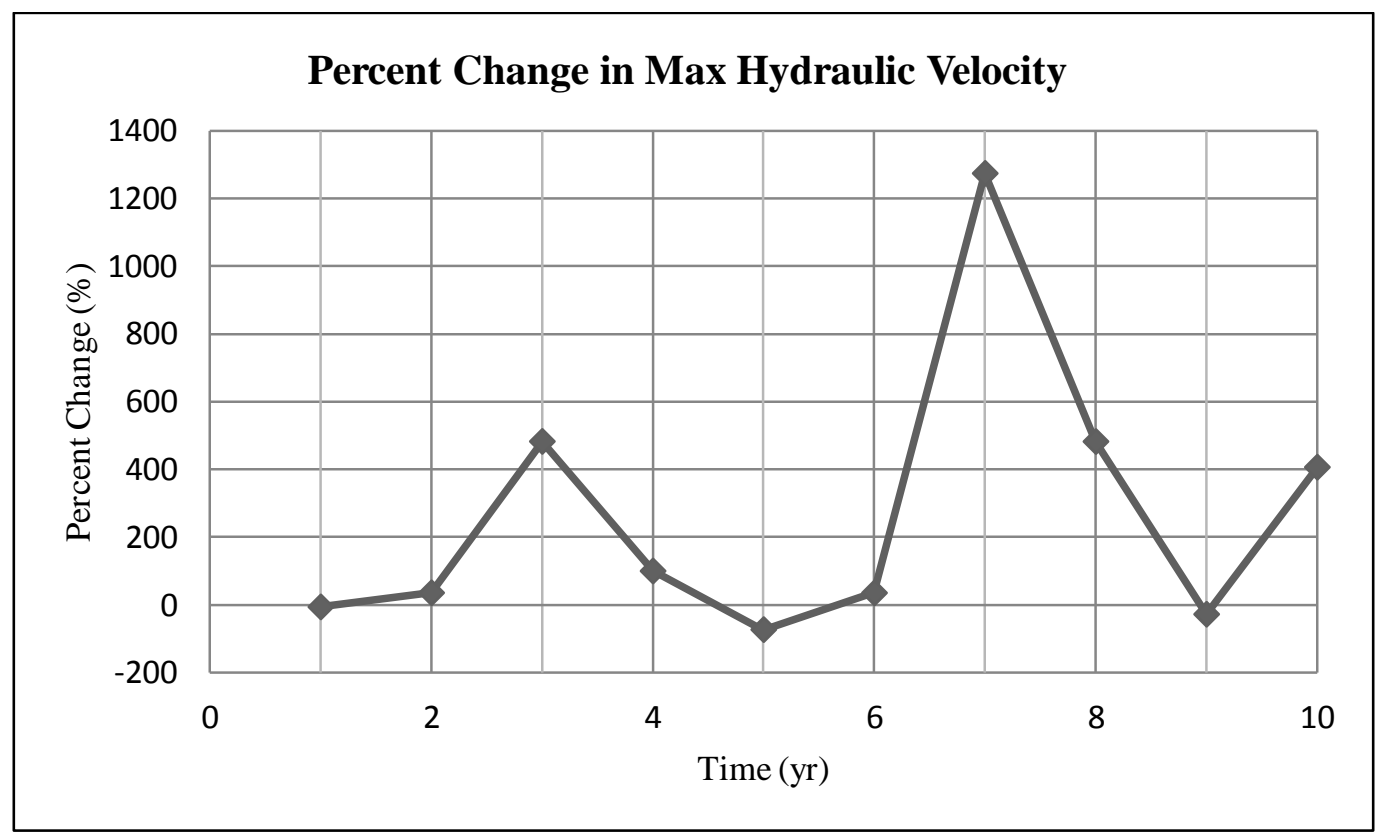

Figure 6.26: Percent change in maximum hydraulic velocity for AOC and geomorphic fills 
The maximum hydraulic velocity throughout each fill followed the same pattern as the water flux at the toe of each fill. The hydraulic velocity of the AOC fill started at a higher magnitude than the geomorphic fill. By year 3, the hydraulic velocity of both fills reached a much lower magnitude. Between years 3 through 10, the velocities fluctuate back and forth. Year 5 showed a spike in the velocity of the AOC fill, whereas the flux of the geomorphic fill stayed at a more stable rate through years 3 through 10 .

The AOC fill had an advantage over the geomorphic fill from years 1-2, 4-6, and at a very short time during year 9. The peak advantages for the AOC fill were $73.6 \%$ at year 5 and $28.2 \%$ at year 9. The geomorphic fill was advantageous from years 2-4 and 6-10 with peaks in advantage of $482.1 \%$ at year 3 and $1273.7 \%$ at year 7 . The magnitude of the advantage for the geomorphic fill was much higher than the magnitude of the advantage for the AOC fill.

\section{Storage}

The final criterion used for comparison of the two fills was water storage within the fill. Table 6.10 below summarizes the normalized storage over time for both the AOC and geomorphic fills. Figures 6.27 and 6.28 show plots of storage over time.

Table 6.9: Comparison of normalized storage results

\begin{tabular}{|c|c|c|c|}
\cline { 2 - 4 } \multicolumn{1}{c|}{} & \multicolumn{3}{c|}{ Normalized Storage $\left(\mathrm{m}^{3} / \mathrm{m}^{3}\right)$} \\
\hline Time (yr) & AOC & Geomorphic & Percent Change (\%) \\
\hline 1 & 9.8 & 7.9 & -19.3 \\
\hline 2 & 15.9 & 15.1 & -5.2 \\
\hline 3 & 16.1 & 16.0 & -0.6 \\
\hline 4 & 16.2 & 16.8 & 3.2 \\
\hline 5 & 22.2 & 16.9 & -23.8 \\
\hline 6 & 23.0 & 17.4 & -24.3 \\
\hline 7 & 22.9 & 18.8 & -17.9 \\
\hline 8 & 22.7 & 19.2 & -15.5 \\
\hline 9 & 23.0 & 19.3 & -16.4 \\
\hline 10 & 23.2 & 20.1 & -13.2 \\
\hline
\end{tabular}




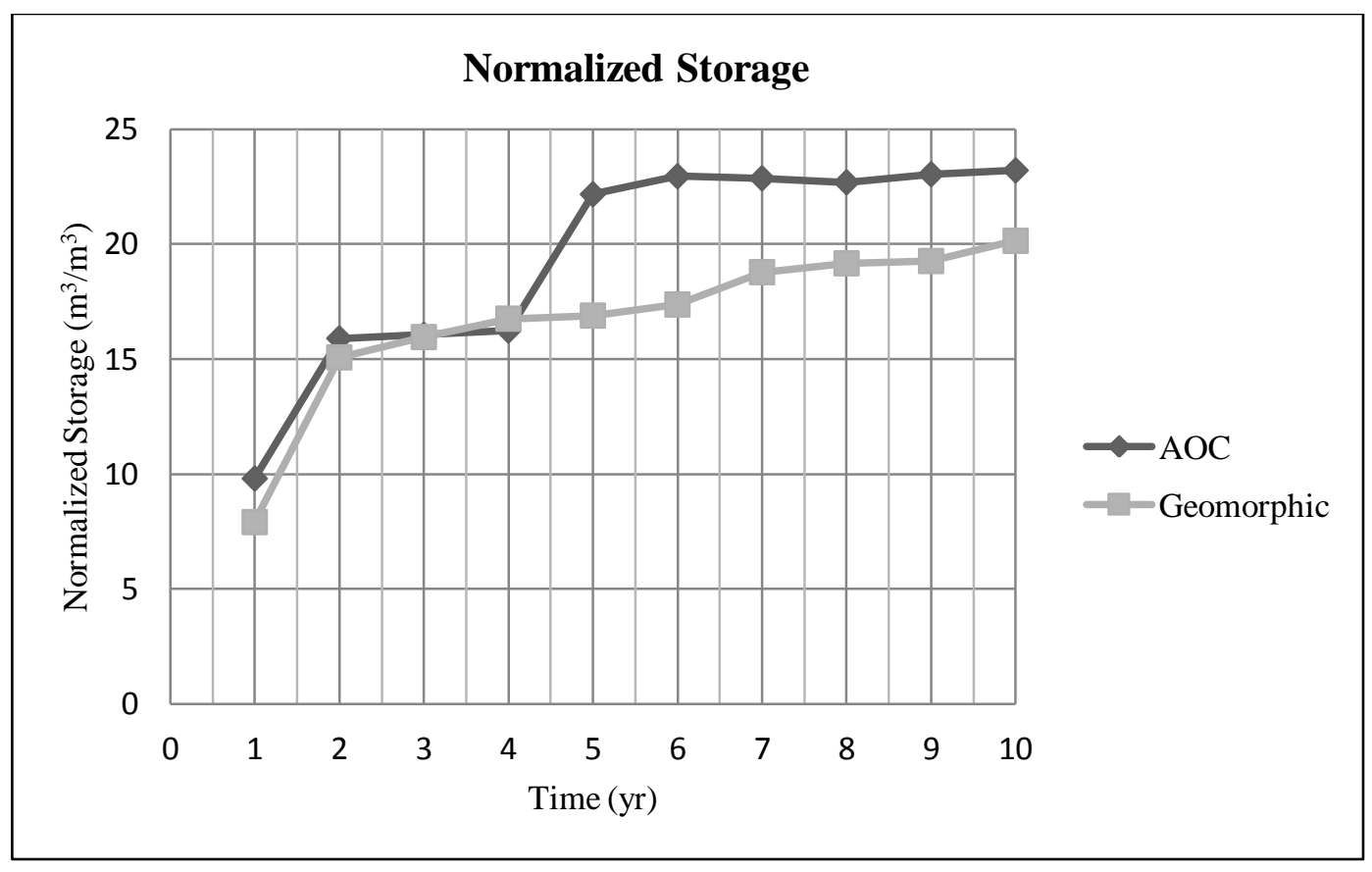

Figure 6.27: Normalized storage over time for both fills

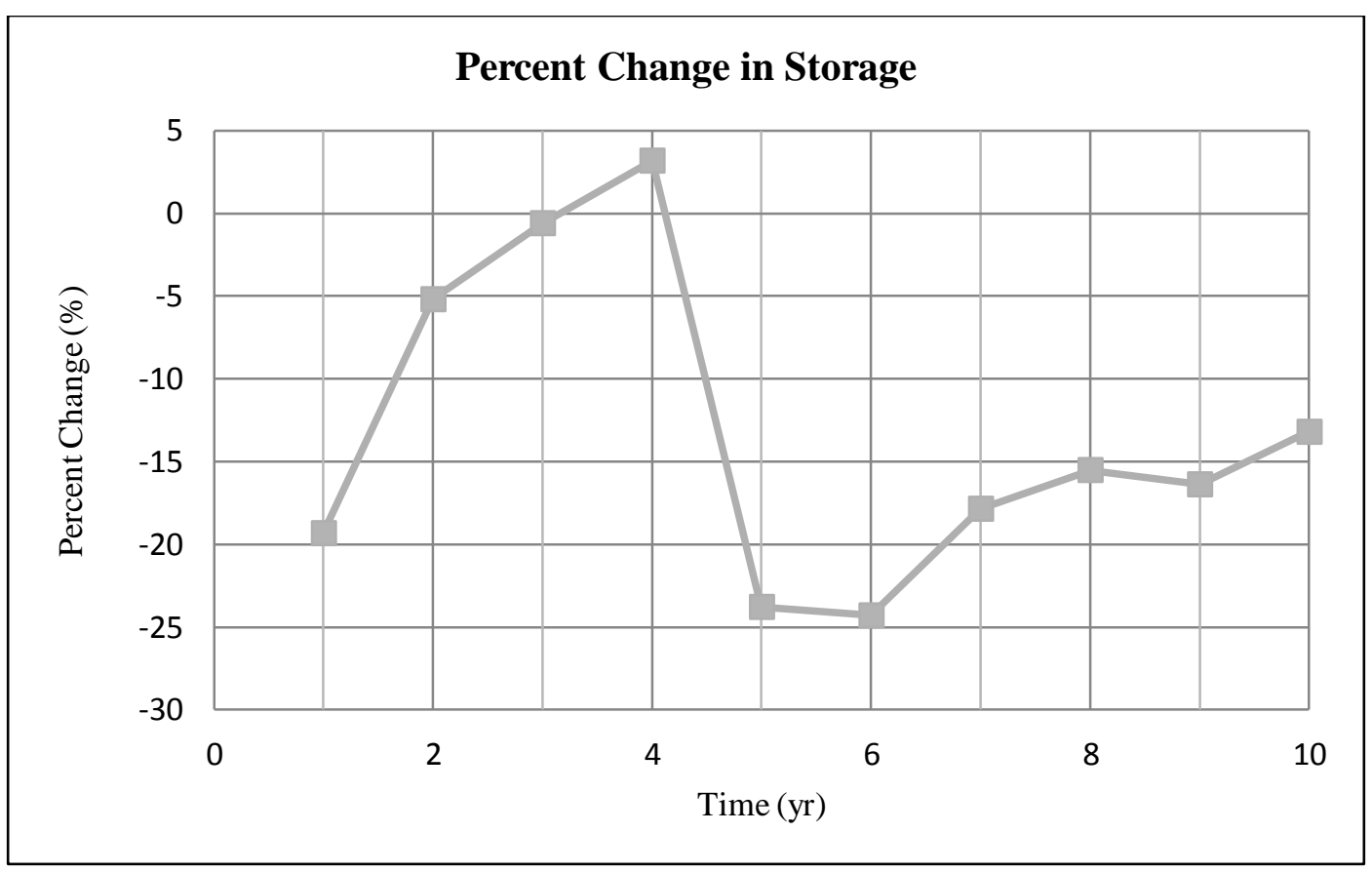

Figure 6.28: Percent change in storage for AOC and geomorphic fills 
The percentage of water stored by the AOC fill was higher than the geomorphic fill for the entire duration except between years 3 and 4, where it showed a slight drop in storage percentage. Both fills showed a sharp increase in storage percentage in the first 2 years. At year 5 , the AOC fill showed a sharp increase in storage percentage which produced a larger difference in storage percentage between the two fills for the second half of the time frame. The geomorphic fill showed a much steadier and smoother increase in storage percentage over time.

The geomorphic fill had an advantage for the duration of the 10 years except between years 3 and 4, where the AOC fill showed an advantage of 3.2\%. The peak in advantage for the geomorphic fill was $24.3 \%$ in year 6 . The magnitude of the advantage for the AOC fill between years 3 and 4 was much lower than the advantage for the geomorphic fill for all the other years.

\section{Summary of Percent Changes}

Since the advantage of one fill over the other was calculated using percent change, each individual criterion of analysis could be compared to see which criteria corresponded to more or less advantage for either fill. Also, the advantage of each fill could be summarized as a whole using all criteria. Table 6.11 below summarizes the advantages of each fill using the percent change values. Cells shaded green indicate a time and criterion that showed an advantage for the geomorphic fill, whereas blue cells correspond to an advantage for the AOC fill. 
Table 6.10: Summary of percent change for AOC and geomorphic fills

\begin{tabular}{|c|c|c|c|c|c|}
\cline { 2 - 6 } \multicolumn{1}{c|}{} & \multicolumn{5}{c|}{ Percent Change (\%) } \\
\hline $\begin{array}{c}\text { Time } \\
(\mathrm{yr})\end{array}$ & $\begin{array}{c}\text { Velocity } \\
\text { at Toe }\end{array}$ & $\begin{array}{c}\text { Water } \\
\text { Flux at } \\
\text { Toe }\end{array}$ & $\begin{array}{c}\text { Max } \\
\text { Hydraulic } \\
\text { Velocity }\end{array}$ & Storage & Total \\
\hline 1 & 211.0 & -12.7 & -6.6 & -19.3 & 172.4 \\
\hline 2 & 400.4 & 21.7 & 35.1 & -5.2 & 452.0 \\
\hline 3 & 1291.1 & 405.4 & 482.1 & -0.6 & 2178.0 \\
\hline 4 & 464.7 & 80.5 & 99.5 & 3.2 & 647.9 \\
\hline 5 & 37.7 & -76.0 & -73.6 & -23.8 & -135.7 \\
\hline 6 & 288.7 & 22.2 & 34.9 & -24.3 & 321.4 \\
\hline 7 & 1646.6 & 1141.7 & 1273.7 & -17.9 & 4044.1 \\
\hline 8 & 843.3 & 424.4 & 481.8 & -15.5 & 1734.0 \\
\hline 9 & -98.2 & -100.0 & -28.2 & -16.4 & -242.7 \\
\hline 10 & 731.7 & 385.4 & 406.1 & -13.2 & 1510.0 \\
\hline Total & 5817.0 & 2292.6 & 2704.8 & -133.0 & $\mathbf{1 0 6 8 1 . 4}$ \\
\hline
\end{tabular}

In every category, the geomorphic fill showed an advantage for the majority of the time steps. The greatest advantage was seen in the velocity at the toe. The next highest advantage was seen in water flux at the toe and maximum hydraulic velocity. Storage showed an advantage for the geomorphic fill for the majority of the model, but with a lower magnitude of advantage. If the percent differences for each criterion and each time step are totaled, it can be seen that the geomorphic fill had an overall advantage throughout the entire 10 year model.

\subsection{Slope Stability}

Based on the results of the SIGMA/W and SLOPE/W analyses, the factor of safety was determined by deterministic and sensitivity analyses for each failure mode. Tables 6.12 and 6.13 below summarize the critical factor safety found for each failure mode for the AOC fill and geomorphic fill. The factor of safety results of the deterministic and sensitivity analyses as a result of seepage are presented, as well as the factor of safety results for the fully saturated case. 
Table 6.11: Factor of safeties for AOC fill

\begin{tabular}{|c|c|c|c|}
\cline { 2 - 4 } \multicolumn{1}{c|}{} & \multicolumn{2}{c|}{ Result of Seepage } & Fully Saturated \\
\hline $\begin{array}{c}\text { Failure } \\
\text { Mode }\end{array}$ & Deterministic & Sensitivity & Deterministic \\
\hline Crest & 1.407 & 1.377 & 0.729 \\
\hline Toe & 1.505 & 1.472 & 0.455 \\
\hline Face & 1.389 & 1.359 & 0.528 \\
\hline Deep & 1.375 & 1.345 & 0.513 \\
\hline
\end{tabular}

Table 6.12: Factor of safeties for geomorphic fill

\begin{tabular}{|c|c|c|c|}
\cline { 2 - 4 } \multicolumn{1}{c|}{} & \multicolumn{2}{|c|}{ Result of Seepage } & Fully Saturated \\
\hline $\begin{array}{c}\text { Failure } \\
\text { Mode }\end{array}$ & Deterministic & Sensitivity & Deterministic \\
\hline Crest & 2.04 & 1.997 & 0.835 \\
\hline Toe & 2.144 & 2.097 & 0.920 \\
\hline Face & 2.242 & 2.194 & 0.912 \\
\hline
\end{tabular}

For the majority of failure modes as a result of groundwater seepage, the AOC fill had a factor of safety less than the valley fill design standard of 1.5. The geomorphic fill, however, had a higher factor of safety of greater than 1.5 for in each case as a result of seepage. Almost all factors of safety were above 2.0, whereas the factors of safety for the AOC fill ranged from 1.3-1.5. This was a result of the geomorphic fill having a less steep slope and draining better than the AOC fill, producing less stress from seepage. For the fully saturated case, both fills had a factor of safety of much less than 1.5. This was a result of the buildup of water causing much higher pore-water pressures than there would be as a result of seepage. This represented the worst possible case, which was not likely to occur in the field. 


\section{CONCLUSIONS}

By analyzing each fill individually, collecting results, and comparing those results, conclusions about the comparison of an AOC fill and geomorphic fill were collected. When looking at the comparison of results between the two fills, the conclusions were as follows:

- For both the AOC and geomorphic fill, the majority of flow was both within the drain and in the saturated zone above the drain. Water within the drain caused a negative porepressure above the drain. This was because the drain was modeled in a saturated only condition. The drain was saturated for the entire duration of the model, so for this reason, the soil retained a saturated zone above the drain. As the zone between the drain and the saturated zone dissipated water, negative pore pressure kept the saturated zone in tension and at a level above the drain. Over time, the level of saturation lowered towards the level of the drain.

- The range of pore-water pressure values for the two fills was almost equal. This is because the geomorphic fill did not alter the soil properties, so the same range of porewater pressures occurred. For each fill, the fill material had the same soil-water characteristic curve, so the behavior of pore-water pressure over time was the same.

- The water velocity of the toe was lower for the AOC fill than for geomorphic fill for every year of the 10 year model except for year 9. Water velocity at the toe showed an advantage for the geomorphic fill for the entire duration other than a short time in year 9 , where the AOC fill had a $98.2 \%$ advantage. The geomorphic fill had peaks in advantage of $1291.1 \%$ at year 3 and $1646.6 \%$ at year 7 .

- Year 5 showed a spike in the water flux at the toe of the AOC fill, whereas the flux of the geomorphic fill stayed at a more stable rate through years 3 through 10. The AOC fill had an advantage over the geomorphic fill with respect to water flux at the toe from years 1-2, 4-6, and 8.5-9.5 with peaks in its advantage of $76.0 \%$ at year 5 and $100.0 \%$ at year 9 . The geomorphic fill is advantageous from years 2-4, 6-8.5, and 9.5-10 with its peaks in advantage of $405.4 \%$ at year 3 and $1141.7 \%$ at year 7 .

- Year 5 showed a spike in maximum hydraulic velocity of the AOC fill, whereas the velocity of the geomorphic fill stayed at a more stable rate through years 3 through 10 . 
The AOC fill had an advantage over the geomorphic fill with respect to maximum hydraulic velocity from years 1-2, 4-6, and at a very short time during year 9 . The peak advantages for the AOC fill were $73.6 \%$ at year 5 and $28.2 \%$ at year 9 . The geomorphic fill was advantageous from years 2-4 and 6-10 with peaks in advantage of $482.1 \%$ at year 3 and $1273.7 \%$ at year 7 .

- The geomorphic fill showed a steadier and smoother increase in storage percentage over time as compared to the AOC design. The geomorphic fill had an advantage for the duration of the 10 years except between years 3 and 4, where the AOC fill showed an advantage of $3.2 \%$. The peak in advantage for the geomorphic fill was $24.3 \%$ in year 6 .

- For water velocity at the toe, water flux at the toe, maximum hydraulic velocity, and storage, the magnitude of the geomorphic fill's advantage was much higher than the advantage for the AOC fill. The advantage was a result of the geomorphic fill moving water through the fill at a faster rate.

When looking at the summary of the percent changes from the AOC fill to geomorphic fill, the following conclusions were made:

- In every category, the geomorphic fill showed an advantage for the majority of the time steps.

- The highest advantage with respect to the magnitude of percent change was seen in the velocity at the toe. The next highest advantage was seen in water flux at the toe and maximum hydraulic velocity.

- Storage showed an advantage for the geomorphic fill for the majority of the model, but with a lower magnitude of advantage than other criteria.

- If the percent differences for each criterion and each time step were totaled, it was seen that the geomorphic fill had an overall advantage throughout the entire 10 year model.

Finally, a comparison of the slope stability results provided the following conclusions:

- For the majority of failure modes as a result of groundwater seepage, the AOC fill had a factor of safety less than the valley fill design standard of 1.5. 
- The geomorphic fill had a higher factor of safety of greater than 1.5 for in each case as a result of seepage. Almost all factors of safety were above 2.0, whereas the factors of safety for the AOC fill ranged from 1.3-1.5. This was a result of the geomorphic fill having a less steep slope and draining better than the AOC fill, producing less stress from seepage.

- For the fully saturated case, both fills had a factor of safety of much less than 1.5. This was a result of the buildup of water causing much higher pore-water pressures than there would be as a result of seepage. This represented the worst possible case, which was not likely to occur in the field.

All of these conclusions pointed to supporting the idea of the geomorphic design of valley fills having advantages over Approximate Original Contour design.

A geomorphic fill showed a distinct advantage in the behavior of groundwater seepage. To further analyze the comparison between a geomorphic and AOC fill, these groundwater seepage results could be applied to contaminant transport. Selenium is a naturally present trace metal that at high concentrations can be toxic to humans and ecosystems and can be released during mining. It is present in coal overburden. Selenium enters ground and surface water by being desorbed from coal waste by water. The geomorphic fill's advantage with regards to seepage could translate into an advantage in contaminant transport. Since the geomorphic fill stored less water and moved water through the fill at a faster rate, there would be less contact time with waste rocks to desorb the selenium. This is something that would have to be investigated further using the CTRAN/W module of GeoStudio to model the contaminant transport. Another area that needs to be investigated to fully compare the differing design techniques is the construction and lifetime cost of implementing a geomorphic fill versus an AOC fill. Also, a longer time period could be analyzed in order to further compare the behavior of groundwater in the AOC and geomorphic fills over an entire design lifetime.

With the limited amount of work that has been done with geomorphic fills in the region of central Appalachia, this research has provided a sound initial analysis to compare with previously used design techniques. Further research must be done in order to make a fully 
informed decision as to whether or not geomorphic design would be feasible to implement in the reclamation of surface mines in central Appalachia. 


\section{REFERENCES}

Abdelghani, F.B., Simon, R., Aubertin, M, Molson, J. \& Therrien, R. (2009). "Use of the hydrogeosphere code to simulate water flow and contaminants transport through mining wastes disposed in a symmetric open pit within fractured rock." Proc. Tailings and Mine Waste. Taylor and Francis Group. Vail, CO. 601-611.

Akan, A.O. (1993). "Losses from rainfall." Urban stormwater hydrology: a guide to engineering calculations. Lancaster, PA. Technomic Publishing Co., Inc, 33.

Albright, W., Benson, C., Gee, G., Abichou, T., Tyler, S., and Rock, S. (2006). "Field performance of three compacted clay landfill covers." Vadose Zone J., 5(6), 1157-1171.

Albright, W., Benson, C., Gee, G., Abichou, T., Tyler, S., and Rock, S. (2006). "Field performance of a compacted clay landfill final cover at a humid site." J. Geotech. And Geoenvironmental Eng., 132(11), 1393-1403.

ASTM Designation D422. (2007). "Standard Test Method for Particle-Size Analysis of Soils." Annual Book of ASTM Standards, American Society of Testing Materials, Easton, MD.

ASTM Designation D698. (2007). "Standard Test Methods for Laboratory Compaction Characteristics of Soil Using Standard Effort $\left(12400 \mathrm{ft}-\mathrm{lbf} / \mathrm{ft}^{3}\left(600 \mathrm{KN}-\mathrm{m} / \mathrm{m}^{3}\right)\right)$." Annual Book of ASTM Standards, American Society of Testing Materials, Easton, MD.

ASTM Designation D854. (2007). "Standard Test Methods for Specific Gravity of Soil Solids by Water Pycnometer." Annual Book of ASTM Standards, American Society of Testing Materials, Easton, MD.

ASTM Designation D2216. (2007). "Standard Test Methods for Laboratory Determination of Water (Moisture) Content of Soil and Rock by Mass." Annual Book of ASTM Standards, American Society of Testing Materials, Easton, MD.

ASTM Designation D2487. (2010). "Standard Practice for Classification of Soils for Engineering Purposes (Unified Soil Classification System)." Annual Book of ASTM Standards, American Society of Testing Materials, Easton, MD.

ASTM Designation D4318. (2007). "Standard Test Methods for Liquid Limit, Plastic Limit, and Plasticity Index of Soils.” Annual Book of ASTM Standards, American Society of Testing Materials, Easton, MD

ASTM Designation D-5856. (2007). "Standard test Method for Measurement of Hydraulic Conductivity of Porous Material using a Rigid-Wall, Compaction-Mold Permeameter." Annual Book of ASTM Standards, American Society of Testing Materials, Easton, MD

Aubertin, M., Bussierre, B. \& Chapuis, R. (1996). "Hydraulic conductivity of homogenized tailings from hard rock mines.” Can. Geotech. J., 33: 470-482. 
Bedient, P.H., Huber, W.C. \& Vieux, B.E. (2008). "Hydrologic principles.” Hydrology and floodplain analysis, $4^{\text {th }}$ ed. M.J. Horton, ed., Prentice-Hall Inc., Upper Saddle River, NJ, 65.

Bell, J.C., Daniels, W.L., and Zipper, C.E. (1989). "The practice of "approximate original contour" in the central Appalachians. I." Slope stability and erosion potential. Landscape Urban Plann., 18, 127-138.

Das, B.M. (2010). "Permeability." Principles of geotechnical engineering. $7^{\text {th }}$ ed. C. Carson, ed., Cenage Learning, Stamford, CT, 165.

Deissmann, G., Goldsworthy, M., Kistinger, S., Stollenwerk, R.H. \& Systemplanung, B. (2003) "Design constraints on engineered dry covers for waste rock dumps." Proc., Mining and the Envir. III Conference. Sudbury, MA.

Fredlund, M.D., Wilson, G.W. \& Fredlund, D.G. (1998). "Estimation of hydraulic properties of an unsaturated soil using a knowledge-based system." Proc., Second Inter. Conf. on Unsat. Soils. Beiling, China.

Huber, W.C. \& R.E. Dickinson. (1998). Storm Sewer Management Model, Version 4, User's Manual. Environmental Research Laboratory, Athens, GA. U.S. Environmental Protection Agency.

Martin-Duque, J.F., Sanz, M.A., Bodoque, J.M., Lucia, A., and Martin-Moreno, C. (2009). Restoring earth surface processes through landform design. A 13-year monitoring of a geomorphic reclamation model for quarries on sloeps. Earth Surface Processes \& Landforms, $35,531-548$.

Meek, A. \& O'dell, K. (2012). "Selenium Treatment Arch-Eastern, Birch Mine." Proc., West Virginia Mine Drainage Task Force Symposium. Morgantown, WV.

MEND Report 2.21.4. (2004). Design, Construction and Performance of Cover Systems for Waste Rock and Tailings. Natural Resources Canada.

Michael, P., Superfesky, M. and Uranoswki, L. (2009). "Challenges of applying geomorphic and stream reclamation methodologies to mountaintop mining and excess spoil fill construction in steep slope topography (e.g. central Appalachia)." Proc., Geomorphic Reclamation Forum, OSM, Bristol, VA.

National Oceanic and Atmospheric Administration. (2012). "Precipitation Frequency Data Server (PFDS)." Hydrometeorological Design Studies Center, <http://hdsc.nws.noaa.gov> (Feb. 10, 2012). 
Palmer, M.A., Bernhardt, E.S., Schlesinger, W.H., Eshleman, K.N., Foufoula-Georgiou, E., Hendryx, M.S., Lemly, A.D., Likens, G.E., Loucks, O.L., Power, M.E., White, P.S. \& Wilcock, P.R. (2010). "Mountaintop mining consequences.” Science. 327, 148-149.

Pitt, R., Chen, S. \& Clark, S. (2001). "Infiltration through compacted urban soils and effects on biofiltration design.” Proc., Low Impact Development Roundtable Conference. Baltimore, MD.

Sharma, K.D., Singh, H.P. \& Pareek, P. (1983). "Rainwater infiltration into a bare loamy sand." Hydrological Sci. J., 28(3), 417-424.

Toy, T.J. and Chuse, W.R. (2005). "Topographical reconstruction: a geomorphic approach." Ecol. Eng., 24, 29-35.

Vesper, D.J., Roy, M., Rhoads, C.J. (2007). "Selenium distribution and mode of occurrence in the Kanawka Formation, southern West Virginia, U.S.A.” Int. J. Coal Geol., 73(3), 237-249.

West Virginia Department of Environmental Protection, Division of Mining and Reclamation. (1999). Permit Handbook: AOC and excess spoil disposal.

West Virginia Department of Environmental Protection. Permit ID 5500809. Pine Creek No. 2 Surface Mine (July 12, 2007).

Ziemkiewicz, P., O'Neal, M., and Lovett, R. (2011). Selenium leaching kinetics and in-situ control. Mine Water \& the Environment, 30(2), 141-150. 